Resistor Printing on Dielectric

Federal Manufacturing \& Technologies

G. E. Barner

KCP-613-6251

Published January 2000

Final Report

Approved for public release; distribution is unlimited.

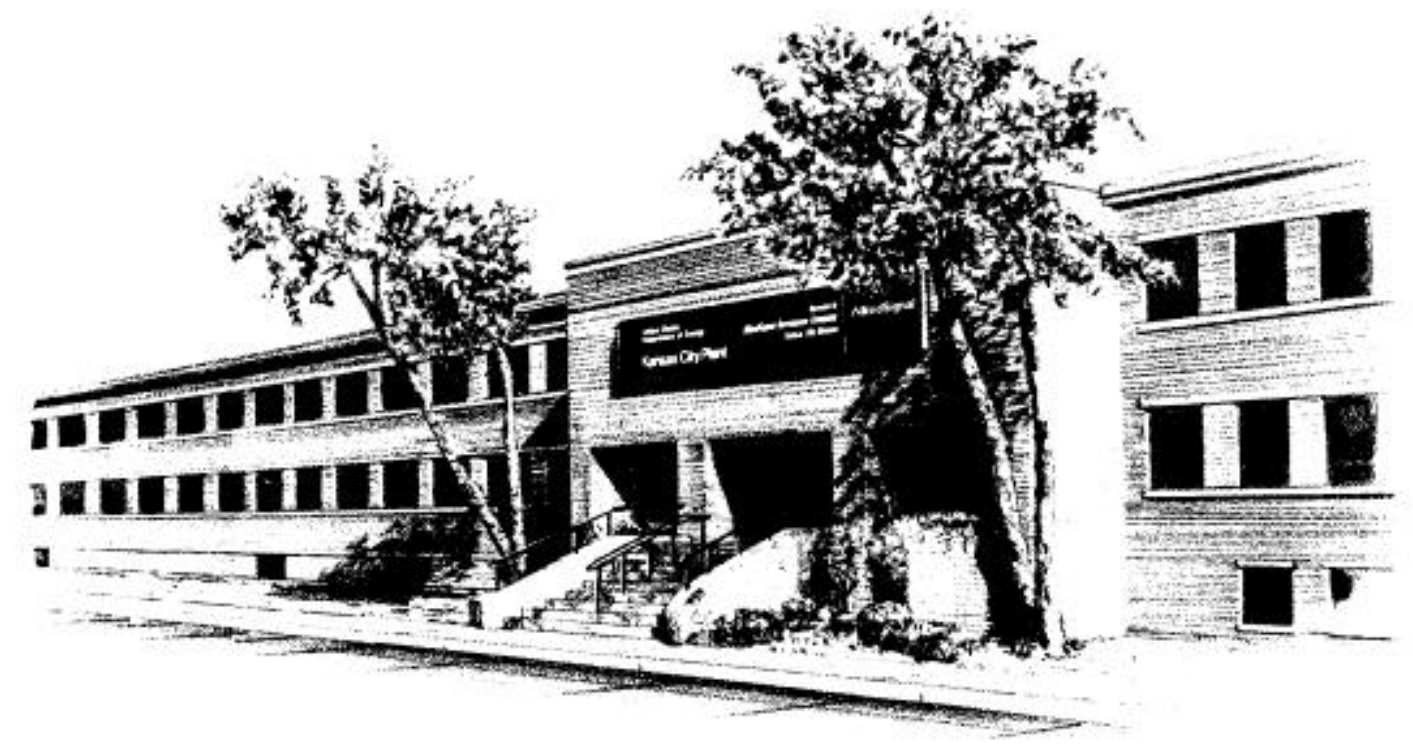

Prepared Under Contract Number DE-ACO4-76-DP00613 for the

United States Department of Energy

\title{
DISCLAIMER
}

This report was prepared as an account of work sponsored by an agency of the United States Government. Neither the United States Government nor any agency thereof, nor any of their employees, makes any warranty, express or implied, or assumes any legal liability or responsibility for the accuracy, completeness, or usefulness of any information, apparatus, product, or process disclosed, or represents that its use would not infringe privately owned rights. Reference herein to any specific commercial product, process, or service by trade names, trademark, manufacturer, or otherwise, does not necessarily 
constitute or imply its endorsement, recommendation, or favoring by the United States Government or any agency thereof. The views and opinions of authors expressed herein do not necessarily state or reflect those of the United States Government or any agency thereof.

All data prepared, analyzed and presented has been developed in a specific context of work and was prepared for internal evaluation and use pursuant to that work authorized under the referenced contract. Reference herein to any specific commercial product, process or service by trade name, trademark, manufacturer, or otherwise, does not necessarily constitute or imply its endorsement, recommendation, or favoring by the United States Government, any agency thereof or Honeywell International Inc.

Printed in the United States of America.

This report has been reproduced from the best available copy.

Available to DOE and DOE contractors from the Office of Scientific and Technical Information, P. O. Box 62, Oak Ridge, Tennessee 37831; prices available from (865) 576-8401, FTS 626-8401.

Available to the public from the National Technical Information Service, U. S. Department of Commerce, 5285 Port Royal Rd., Springfield, Virginia 22161, (703) 487-4650.

Honeywell

Federal Manufacturing

\& Technologies

P. O. Box 419159

A prime contractor with the United States

Kansas City, Missouri

Department of Energy under Contract Number

64141-6159

DE-ACO4-76-DP00613.

Honeywell

KCP-613-6251

Distribution Category UC-706 
Approved for public release; distribution is unlimited.

\section{RESISTOR PRINTING ON DIELECTRIC}

G. E. Barner

Published January 2000

Final Report

G. E. Barner, Project Leader

Project Team:

S. W. Bandler

J. E. Guffey

\section{Contents}

Section

Abstract

Summary

Discussion

Scope and Purpose

Prior Work

Activity

Test Plan

Test Sample Configuration and Fabrication

Print Thickness Considerations 
Untrimmed Resistance Measurements

Normalized Sheet Resistance and Design Considerations

Firing Sensitivity

Encapsulation Effects on Untrimmed Resistance

Thickness Sensitivity

Effects of Resistor Geometry and Orientation

Substrate Comparison

Overall Printing/Firing Capability

Resistor Series Comparison for Untrimmed Resistances

Determination of Resistor Trimming Operating Envelope

Resistor Performance Trimmed at the Operating Point

Resistor Trim Test Descriptions

Resistor Trim Requirements

Application of Requirements

Resistivity Specific Data and Observations

Accomplishments

Future Work

References

Appendices

A. Summary Data for Untrimmed Du Pont 2000 Series Resistors Printed on Alumina

B. Comparative Data for Untrimmed Du Pont 1400/2000 Series Resistors Printed on Alumina

C. Du Pont 2011 Resistor Printing Data - 10 Ohm Resistor

D. Du Pont 2021 Resistor Printing Data - 100 Ohm Resistor

E. Du Pont 2031 Resistor Printing Data - 1K Ohm Resistor

F. Du Pont 2041 Resistor Printing Data - 10K Ohm Resistor

G. Du Pont 2051 Resistor Printing Data - 100K Ohm Resistor

H. Du Pont 2061 Resistor Printing Data - 1Meg Ohm Resistor 
I. Test Results for Laser Trimmed Du Pont 2011 Paste - 10 Ohm Resistor

J. Test Results for Laser Trimmed Du Pont 2021 Paste - 100 Ohm Resistor

K. Test Results for Laser Trimmed Du Pont 2031 Paste - 1K Ohm Resistor

L. Test Results for Laser Trimmed Du Pont 2041 Paste - 10K Ohm Resistor

M. Test Results for Laser Trimmed Du Pont 2051 Paste - 100K Ohm Resistor

N. Test Results for Laser Trimmed Du Pont 2061 Paste - 1Meg Ohm Resistor

\title{
Illustrations
}

Figure

1 Two-Square Resistor Test Pattern

2 Resistor Sintering Time/Temperature Profiles

Tables

Number

1 Evaluated Laser Parameters (5415D Glaze)

2 Evaluated Laser Parameters (No Glaze)

3 Laser Operating Points (5415D Glaze)

4 Laser Operating Points (No Glaze)

5 Stability for Resistors Trimmed at the Operating Point (5415D Glaze)

6 Stability for Resistors Trimmed at the Operating Point (No Glaze)

7 Recommended Tolerance (5415D Glaze)

8 Recommended Tolerance (No Glaze)

9 Unglazed

10 Glazed

\begin{abstract}
Design and processing parameters were developed for a new thick film resistor system for use in the fabrication of thick film hybrid microcircuits at Honeywell Federal Manufacturing \& Technologies. This characterization was performed in two phases. First, resistor application processes (screen printing, drying, and firing) were characterized. Second, the characterization of the laser trimming process used to adjust resistor values to the final acceptable values was performed.

Summary
\end{abstract}


Evaluations were performed initially to establish the process parameters for manufacturing microelectronic circuits using integral thick film resistors fabricated from Du Pont 1900 series resistor compositions printed directly on dielectric which had previously been printed on 96 percent alumina substrates.

This project was intended to provide a higher yield thick film resistor fabrication method by eliminating the substrate topography associated with resistor printing directly on ceramic required by existing Honeywell Federal Manufacturing \& Technologies (FM\&T) manufacturing processes using Du Pont 1400 series resistor compositions.

After preliminary evaluations of Du Pont 1900 series resistor compositions it was determined that the newly developed Du Pont 2000 series resistor compositions would be a more suitable candidate for two reasons. First, the Du Pont 2000 series had just been qualified for the low temperature cofired ceramic (LTCC) production at FM\&T and, secondly, the Du Pont 2000 series offered the advantage of being cadmium free, compared to the cadmium-containing Du Pont 1900 series resistor compositions.

Initial tests were performed for Du Pont 2000 series resistors printed on dielectric before a decision was made to change the focus of the project again to evaluate

Du Pont 2000 for printing directly on alumina as an overall replacement for the production thick film hybrid microcircuit resistor system. Production use of Du Pont 2000 series resistor compositions on thick film hybrid microcircuits would have several benefits as follows:

- Elimination of existing carcinogenic resistor production materials, specifically Du Pont 1400 series resistor compositions and Du Pont 9137 encapsulant composition.

- Potentially higher production yields and reduced equipment setup times resulting from less process sensitivity of resistor fabrication materials.

- Simplification of material control and production operations by using one common resistor material for both thick film and LTCC resistor fabrication.

- Ultimate elimination of the Du Pont 1400 series resistors from FM\&T production before product availability becomes an issue as a result of low volume sales by Du Pont.

- The evaluation of Du Pont 2000 series resistors printed on alumina was performed for six resistivity compositions $(10,100,1 \mathrm{~K}, 10 \mathrm{~K}, 100 \mathrm{~K}$ and $1 \mathrm{meg}$ ohm per square) in conjunction with the evaluation of laser trimming Du Pont 2000 series resistors printed on $96 \%$ alumina substrates. Both evaluations support an effort to improve a production capability utilizing integral thick film resistors on thick film hybrid microcircuit products.

Test samples were fabricated using a two-square test pattern configuration consisting of resistors with length to width aspect ratios of 2:1 and minimum dimensions of $0.025 ", 0.050 "$, and $0.100 "$. The test pattern configuration is illustrated in Figure 1 in the Discussion section. The test samples were printed on 96\% alumina substrates with and without encapsulation. Encapsulation material used was Du Pont 5415D. The manufacturer recommended encapsulant for 2000 series resistors, printed to a dried thickness of 20 microns and fired at 600 degrees $C$ for 5 minutes. Resistor termination material used on the test samples was Du Pont 4596 platinum/gold conductor composition, typical of production at FM\&T. Test samples were fired at 825, 850 and 875 degrees $\mathrm{C}$ using 30-minute profiles. Test samples were also fired in each of three production thick film sintering furnaces.

Test samples for the laser trimming characterization were processed using nominal print thicknesses (18 to 20 microns dried) and firing temperatures (850 degrees $\mathrm{C}-$

30-minute profile). Half of the samples for the laser trimming characterization were encapsulated and 
half were not to evaluate the effects of encapsulation on resistor stability. Test samples were trimmed using laser settings for bite size, $\mathrm{Q}$ rate, and power. Samples were then subjected to the following tests:

- Isolation resistance;

- 24-hour short-term drift;

- Temperature shock (solder pot shock test): $25^{\circ} \mathrm{C}$ to $268^{\circ} \mathrm{C}, 268^{\circ} \mathrm{C}$ for 15 seconds and back to $25^{\circ} \mathrm{C}$;

- Temperature cycle: $-50^{\circ} \mathrm{C}$ to $125^{\circ} \mathrm{C}$ with approximately 5 seconds ramp time, ten cycles, 15 minutes minimum at each temperature extreme;

- 1000-hour aging test at $150^{\circ} \mathrm{C}$, ambient humidity.

Resistance was measured after each test, and the change in resistance was calculated.

Using visual requirements, isolation resistance, and the results of the above tests, resistor performance was characterized.

The evaluation determined Du Pont 2000 series resistors can be used as an alternative to Du Pont 1400 series resistors in the FM\&T thick film hybrid microcircuit fabrication processes. The evaluation also established the following material characteristics, design criteria, and manufacturing parameters for the six Du Pont 2000 series resistor compositions:

1. Target print thicknesses for each of the six pastes ranged from 28 to 32 microns to yield the Du Pont recommended dried thickness of 18-22 microns resulting in optimum as-fired resistances and maximum post-trim resistor stability.

2. Du Pont 2000 series thick film resistors printed on alumina substrates should be designed to $70 \%$ of trimmed nominal value except for resistors utilizing the 100-ohm (Du Pont 2021) and the 1meg-ohm (Du Pont 2061) resistor composition. Based on initial results, resistors employing either the 100-ohm (Du Pont 2021) resistor composition or the 1meg-ohm (Du Pont 2061) resistor composition should be designed to $60 \%$ of trimmed nominal value.

3. Average resistances for all six Du Pont 2000 series compositions printed on alumina ranged from $54 \%$ above nominal to $9 \%$ below nominal. This range is similar (with the exception of the 100 -ohm and 1meg-ohm compositions) to Du Pont 1400 series resistors (23\% above nominal to $23 \%$ below nominal) used on existing thick film production designs.

4. Encapsulation of resistors did not significantly improve resistor stability and typically had minimal effect on pre-trimmed resistances. The 100-ohm and 1K-ohm compositions exhibited a 1-5\% increase; $10-\mathrm{ohm}, 10 \mathrm{~K}$-ohm, and 100K-ohm compositions exhibited a 1-5\% decrease; and the $1 \mathrm{meg}$-ohm composition increased $10 \%$ with encapsulation.

5. Resistances were less affected by resistor orientation and were more dependent on resistor geometry. Resistors parallel to squeegee travel averaged 2-13\% lower than resistors perpendicular to squeegee travel. Resistances of 25-mil resistors averaged13-28\% lower than 50-mil resistors, and 100-mil resistors averaged 6-21\% higher than 50-mil resistors.

6. Overall print lot capability (+/- 3 sigma) was $+/-35 \%$ from average fired values for all pastes except the 100-ohm composition (Du Pont 2021) which was $+/-50 \%$ and the 1 meg-ohm composition (Du Pont 2061) which was $+/-40 \%$. These values are comparable to the fired values achieved in existing FM\&T production with

Du Pont 1400 series resistors.

7. Resistor stability was determined for pastes trimmed at the operating points as follows: 


\begin{tabular}{|r|r|r|r|r|r|r|}
\hline \multicolumn{2}{|c|}{ STAEILITY FOR RESISTORS TRIMMED AT THE OPERATING POINT (5415D GLAZE) } \\
\hline \hline \multirow{3}{*}{ Paste } & \multicolumn{6}{|c|}{ Resistor Width (mils) } \\
\cline { 2 - 7 } & \multicolumn{5}{|c|}{25} & \multicolumn{3}{c|}{50} \\
\cline { 2 - 7 } & \multicolumn{3}{|c|}{$\%$ Change In Resistance After All Tests } \\
\cline { 2 - 7 } & Average & Low & \multicolumn{1}{c|}{ High } & Average & \multicolumn{1}{c|}{ Low } & High \\
\hline 2011 & 0.525 & 0.342 & 0.777 & 0.394 & 0.250 & 0.618 \\
\hline 2021 & 0.140 & 0.037 & 0.373 & 0.094 & 0.017 & 0.162 \\
\hline 2031 & 0.101 & -0.040 & 0.200 & 0.083 & -0.013 & 0.159 \\
\hline 2041 & 0.124 & -0.106 & 0.289 & 0.068 & -0.063 & 0.284 \\
\hline 2051 & 0.103 & -0.098 & 0.275 & 0.075 & -0.057 & 0.177 \\
\hline 2061 & 0.111 & -0.437 & 0.506 & 0.219 & -0.161 & 0.610 \\
\hline
\end{tabular}

\begin{tabular}{|c|c|c|c|c|c|c|}
\hline \multicolumn{7}{|c|}{ ST AEILITY FOR RESISTORS TRIMMED AT THE OPERATING POINT (NO GLAZE) } \\
\hline \multirow{4}{*}{ Paste } & \multicolumn{6}{|c|}{$\begin{array}{ll}\text { Resistor Width (mils) } \\
\end{array}$} \\
\hline & \multirow{2}{*}{\multicolumn{3}{|c|}{$\%$ Change In Resist }} & \multicolumn{3}{|c|}{50} \\
\hline & & & & nce After & Tests & \\
\hline & Average & Low & High & Average & Low & High \\
\hline 2011 & 0.568 & 0.436 & 0.756 & 0.526 & 0.414 & 0.926 \\
\hline 2021 & 0.151 & 0.015 & 0.332 & 0.122 & 0.031 & 0.229 \\
\hline 2031 & 0.115 & -0.040 & 0.328 & 0.086 & -0.032 & 0.278 \\
\hline 2041 & 0.140 & -0.028 & 0.394 & 0.124 & -0.060 & 0.236 \\
\hline 2051 & -0.053 & -0.452 & 1.039 & -0.049 & -0.325 & 0.194 \\
\hline 2061 & 0.105 & -0.165 & 0.429 & 0.339 & -0.097 & 0.965 \\
\hline
\end{tabular}

- Final trimmed resistor tolerances were established as follows:

\begin{tabular}{|c|c|c|}
\hline \multicolumn{2}{|c|}{ RECOMMENDE TOLERANCE (5415D GLAZE) } \\
\hline \hline \multirow{2}{*}{ Paste } & \multicolumn{2}{|c|}{ Resist or Width (mils) } \\
\hline & 25 & 50 \\
\cline { 2 - 3 } & \multicolumn{2}{|c|}{ TOLERANCE $(+/-\%)$} \\
\hline 2011 & 1.6 & 1.2 \\
\hline 2021 & 1.2 & 1.0 \\
\hline 2031 & 1.2 & 1.0 \\
\hline 2041 & 1.2 & 1.0 \\
\hline 2051 & 1.0 & 1.0 \\
\hline 2061 & 2.0 & 2.0 \\
\hline
\end{tabular}




\begin{tabular}{|c|c|c|}
\hline \multicolumn{2}{|c|}{ RECOMMENDED TOLERANCE (NO GLAZE) } \\
\hline Paste & \multicolumn{2}{|c|}{ Resist or Width (mils) } \\
\hline & 25 & 50 \\
\cline { 2 - 3 } & \multicolumn{2}{|c|}{ TOLERANCE (+/-\%) } \\
\hline 2011 & 1.5 & 1.5 \\
\hline 2021 & 1.2 & 1.0 \\
\hline 2031 & 1.0 & 1.0 \\
\hline 2041 & 1.2 & 1.0 \\
\hline 2051 & 2.0 & 1.0 \\
\hline 2061 & 2.0 & 2.0 \\
\hline
\end{tabular}

- Resistor TCR performance for these samples was determined. Cold TCR for 2021, glazed and unglazed, is not within the range published by Du Pont. Hot TCR for the 2031 and 2061, glazed and unglazed, is not within the published range. TCR performance was as follows:

\begin{tabular}{|c|c|c|c|c|c|}
\hline \multicolumn{6}{|c|}{ GLAZED } \\
\hline \multirow[t]{2}{*}{ PASTE } & \multicolumn{3}{|c|}{ RESISTANCE (Ohms) @ TEMPERA TURE } & \multicolumn{2}{|c|}{$\mathrm{TCR}\left(\mathrm{ppm} /{ }^{\circ} \mathrm{C}\right)$} \\
\hline & "R@25" & "R@- $-55^{\circ}$ & "R@125 & TCR $@-55^{\circ}$ & TCR $@ 125^{\circ}$ \\
\hline Ohms & 36.670 & 36.836 & 36.781 & -56.586 & 30.270 \\
\hline 2021 K Ohms & 435.740 & 440.127 & 433.877 & -125.840 & -42.763 \\
\hline 2031 K Ohms & 3.645 & 3.629 & 3.670 & 56.013 & 68.587 \\
\hline $2041 \mathrm{~K}$ Ohms & 29.256 & 29.318 & 29.378 & -26.348 & 41.701 \\
\hline $2051 \mathrm{KOhms}$ & 252.910 & 253.877 & 253.900 & -47.777 & 39.144 \\
\hline 2061 M Ohms & 4.487 & 4.521 & 4.488 & \begin{tabular}{|l}
-93.789 \\
\end{tabular} & $\begin{array}{r}2.229 \\
\end{array}$ \\
\hline Specification ${ }^{*}$ & & & & $>-75$ & $<50$ \\
\hline
\end{tabular}

*Du Pont

\begin{tabular}{|c|c|c|c|c|c|}
\hline \multicolumn{6}{|c|}{ UNGLAZED } \\
\hline \multirow[t]{2}{*}{ PASTE } & \multicolumn{3}{|c|}{ RESISTANCE (Ohms) @ TEMPERA TURE } & \multicolumn{2}{|c|}{$\operatorname{TCR}\left(p p m /{ }^{\circ} \mathrm{C}\right)$} \\
\hline & "R@25" & "R@- $-55^{\circ}$ & "R@125" & TCR $@-55^{\circ}$ & TCR $@ 125^{\circ}$ \\
\hline Ohms & 34.853 & 34.913 & 34.926 & -21.519 & 20.945 \\
\hline 2021 K Ohms & 480.360 & 485.517 & 478.237 & -134.196 & -44.196 \\
\hline 2031 K Ohms & 3.758 & 3.744 & 3.778 & 46.567 & 53.220 \\
\hline $2041 \mathrm{~K}$ Ohms & 42.200 & 42.425 & 42.228 & -66.647 & 6.635 \\
\hline 2051 KOhms & 278.123 & 279.724 & 278.485 & -71.956 & 13.016 \\
\hline 2061 M Ohms & 4.365 & 4.4 & 4.367 & -100.229 & $\begin{array}{r}4.582 \\
\end{array}$ \\
\hline Specification ${ }^{*}$ & & & & $>-75$ & $<50$ \\
\hline
\end{tabular}

*Du Pont

- Encapsulation does not significantly improve resistor stability.

- Du Pont 2000 series resistor pastes can be used as an alternative to Du Pont 1400 series resistor pastes printed on $96 \%$ alumina substrates using Du Pont 4596 platinum/gold conductor terminations.

Discussion 
Scope and Purpose

The objective of this project evolved from initially evaluating resistor compositions printed on dielectric to evaluating a resistor system for general purpose thick film printing. The project objective evolved primarily due to the following:

- The advent of Low Temperature Cofired Ceramic (LTCC) technology into a production capability at Honeywell Federal Manufacturing \& Technologies (FM\&T) since LTCC products achieved higher circuit densities without the need to print on thick film dielectric materials;

- A need for a thick film resistor fabrication method with less sensitivity to process variations;

- Ability to implement an environmentally safer material by replacing existing cadmium-containing process materials with cadmium-free materials;

- A need to minimize the quantity of materials required at FM\&T to support thick film and LTCC production work by ultimately using a single resistor system for both technologies;

- Develop a capability to use an alternative thick film resistor material at FM\&T in view of Du Pont potentially ceasing production of the Du Pont 1400 series resistor materials due to relatively low sales volume.

In the evaluation of all materials (Du Pont 1900 on dielectric and Du Pont 2000 on dielectric and alumina) the intent was to determine the following characteristics for all resistor compositions printed in an effort to improve an existing production capability:

1. Target print thickness consistent with manufacturer's recommendations and compatible with subsequent resistor firing and trimming processes for each resistor composition;

2. Resistor physical design requirements compatible with FM\&T manufacturing processes;

3. Sensitivity of resistance to variations in manufacturing processes, primarily print thickness, firing temperature, and resistor trimming;

4. Effects of geometry variations on resistance and stability;

5. Effects of encapsulation on resistance and stability;

6. Determination of resistor trimming parameters;

7. Trimmed resistor performance determination, including

- Isolation resistance;

- 24-hour short-term drift;

- Temperature shock (solder pot shock test): $25^{\circ} \mathrm{C}$ to $268^{\circ} \mathrm{C}, 268^{\circ} \mathrm{C}$ for 15 seconds, and back to $25^{\circ} \mathrm{C}$;

- Temperature cycle: $-50^{\circ} \mathrm{C}$ to $125^{\circ} \mathrm{C}$ with approximately 5 seconds ramp time, ten cycles, 15 minutes minimum at each temperature extreme;

- 1000-hour aging test at $150^{\circ} \mathrm{C}$, ambient humidity.

\section{Prior Work}

Thick film technology was developed to meet the requirements of RF applications and multilayer circuits originally utilizing thick film resistors fabricated from Du Pont 1400 series resistor compositions printed on the base $96 \%$ aluminum oxide substrate.

This project examined the Du Pont 1900 and 2000 series resistor compositions for printing on Du Pont 851 and 951 Low Temperature Cofired Ceramics. The characterization was described in 
several reports.

Du Pont 1931 and 1949 resistor pastes have been used to print resistors on Du Pont 851 substrates at FM\&T. Du Pont 1931 resistor paste has also been used to print resistors on Du Pont 951 substrates. These resistors have been laser trimmed, and this process has been characterized.

Evaluation of the 2000 series resistor pastes on 951 substrates was undertaken by Du Pont. ${ }^{1}$

An extensive study was conducted on Du Pont 1900 series resistors printed on Du Pont 951 substrates. The samples were printed and laser trimmed by CTS Corp., and the testing was conducted by FM\&T.

Evaluation of printing, drying, and firing Du Pont 2000 series resistors on Du Pont 951 substrates was performed at FM\&T.

The process of laser trimming Du Pont 2011 through 2061 resistors on 951 LTCC substrates has been characterized on the Teradyne W419 Laser Trim System.

Characterization of the laser trimming process on Du Pont 2021 through 2051 resistor pastes, using a General Scanning W670 laser trim system, was accomplished in 1998. Characterization of the laser trimming process on Du Pont 2011 and 2061 resistor pastes, using a General Scanning W670 laser trim system, was accomplished in 1998.

Du Pont changed the frit on their 951 tape. The performance of Du Pont 2000 series resistor paste printed on the 951 tape with new frit was characterized.

The initial phases of this project evaluated the Du Pont 1900 and 2000 series resistor compositions for printing on Du Pont 5704 dielectric.

\section{Activity}

Test Plan

A plan was developed to perform an evaluation of Du Pont 2000 series resistor compositions for use in printing, drying, firing, and laser trimming integral thick film resistors directly on alumina substrate material within the existing FM\&T thick film technology. The evaluation was to ensure similar performance to existing production thick film technology.

The plan utilized a test sample design, which has been used at FM\&T in the evaluation of other production resistor systems providing a method of data comparison between resistor systems. For this evaluation, resistor application processes were centered around Du Pont's recommendations for print thickness and firing parameters.

The resistor trimming portion of the evaluation involved two phases: first determining the operating envelope for the laser parameters using samples from each resistor composition, 
followed by the determination of resistor performance of resistors trimmed at the operating parameters. The acceptable operating range of the laser was determined based on visual criteria, isolation resistance, and resistor stability.

\section{Test Sample Configuration and Fabrication}

The evaluation consisted of printing test samples for each of the six resistor compositions, Du Pont 2011, 2021, 2031, 2041, 2051 and 2061, on 96\% alumina substrates using a two-square resistor test pattern with each resistor having a length to width ratio of two. The test pattern shown in Figure 1 provided resistors of $0.025 \mathrm{inch}, 0.050 \mathrm{inch}$, and $0.100 \mathrm{inch}$ widths oriented with the resistor lengths parallel and perpendicular to the direction of squeegee travel to simulate actual production. The two-square test patterns provide resistors, which have nominal untrimmed resistances of twice the nominal as-fired sheet resistance. Each test pattern contained two resistors of each width in each orientation.

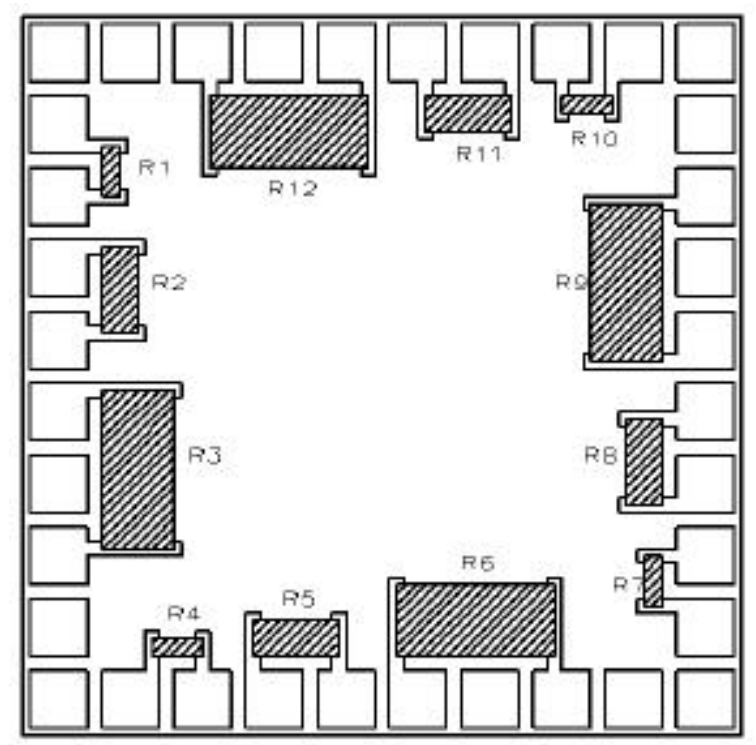

Figure 1. Two-Square Resistor Test Pattern

Test patterns were printed on substrates containing nine test patterns each. The test sample substrates were comprised of 0.025-inch thick 96\% alumina. Du Pont 4596 platinum/gold conductor terminations were used in the evaluation. The test samples were dried using the Du Pont recommended drying profile of 10 minutes at 150 degrees $\mathrm{C}$.

Test sample sintering (firing) for each resistor composition was performed using the nominal 850-degree $\mathrm{C}$ - 30-minute, 825-degree $\mathrm{C}$ - 30-minute, and 875-degree $\mathrm{C}$ -

30 -minute time and temperature profiles. The 30 -minute firing profiles reduce firing times compared to the 60-minute, 850-degree $\mathrm{C}$ time and temperature profile used in thick film production utilizing Du Pont 1400 series resistors. Both profiles provide a peak temperature of 850 degrees $\mathrm{C}$ with a time at peak temperature of 10 minutes. The 30 -minute and 60 -minute profiles maintain approximate ascent and descent rates of 100 and 50 degrees $\mathrm{C}$ per minute, respectively, as illustrated in Figure 2. 


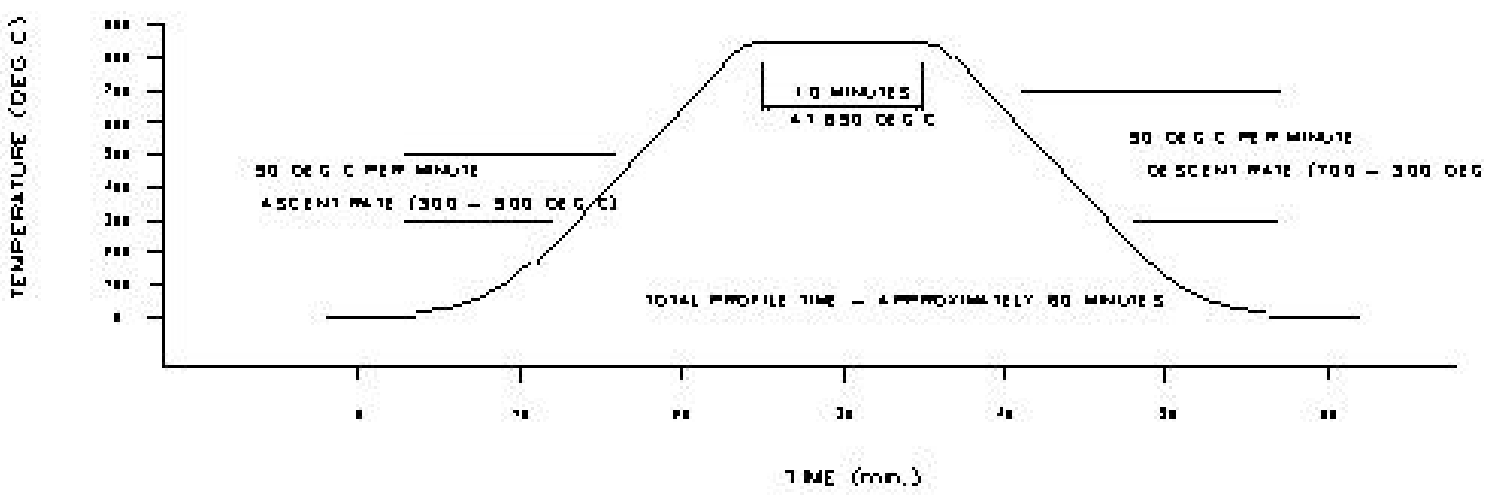

SO MINUTE EOO OEG C THICK FIM SNIER NG PROFIL

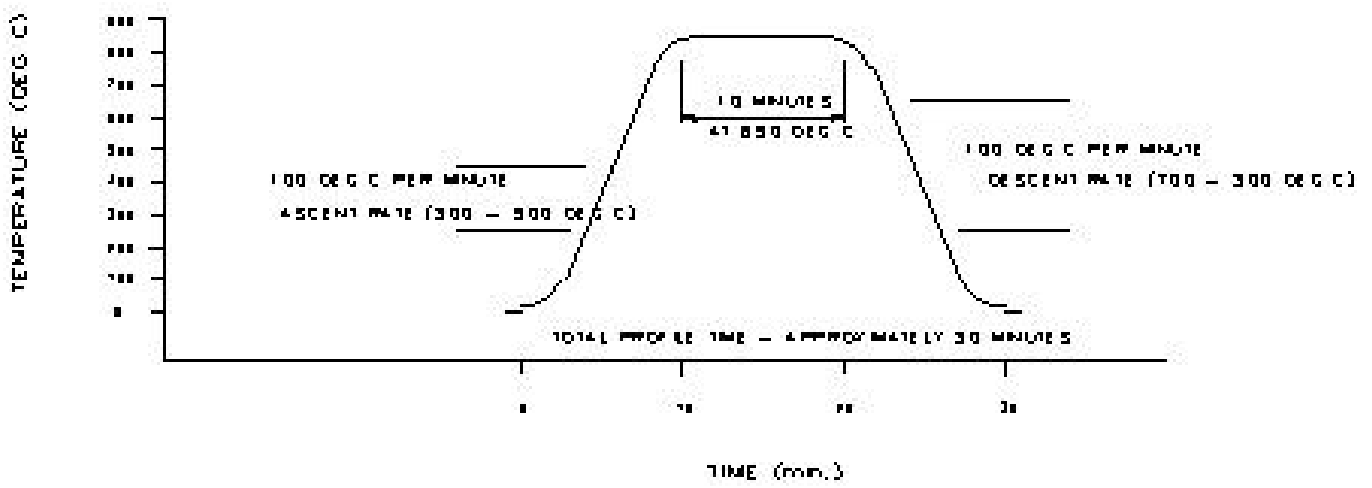

Figure 2. Resistor Sintering Time/Temperature Profiles

Twenty-seven (27) test samples were generated for each combination of furnace, time-temperature profile, and encapsulation for each of the six resistor materials in the printing evaluation.

Test samples used for the laser trimming evaluation were processed at manufacturers recommended thicknesses and firing temperatures as follows.

- Eighty-six (86) samples were prepared using the 2011 resistor paste. Forty-two (42) samples had the resistors covered with Du Pont 5415D glaze. The remaining forty-four (44) were not.

- Seventy-two (72) samples were prepared using the 2021, 2031, 2041, and 2051 resistor pastes. Thirty-six (36) samples had their resistors covered with Du Pont 5415D glaze and thirty-six (36) were not. Eighty-four (84) samples were prepared using the Du Pont 2061 resistor paste. Forty-two (42) samples were covered with the Du Pont 5415D glaze. The 
remaining forty-two (42) were not covered with glaze.

The laser trimming test samples were printed to the dried target thickness range recommended by Du Pont of 18 to 20 microns compared to the 23 to 27 micron range for Du Pont 1400 series compositions. Test samples were prepared both with and without glass encapsulation. The glass encapsulation used was Du Pont 5415D printed to a dried thickness of 18 to 20 microns, dried at 150 degrees $\mathrm{C}$ for 10 minutes and fired at 600-620 degrees $\mathrm{C}$ for 5 to 10 minutes.

\section{Print Thickness Considerations}

The manufacturer's recommended dried thickness for Du Pont 2000 series resistors is 18 to 20 microns. The evaluation established a target wet print thickness needed to obtain a dried thickness of 18 to 20 microns. Figure A-19 illustrates the comparison between wet, dried, and fired thicknesses for each paste composition.

Untrimmed Resistance Measurements

As part of the overall evaluation of the sensitivity of Du Pont 2000 series resistor compositions to variations in manufacturing processes, such as thickness and geometry, electrical resistance measurements were made on as-fired (untrimmed) resistors. The untrimmed resistance data is shown for each resistor composition in the appropriate appendix both as a percent from nominal and actual resistance.

Normalized Sheet Resistance and Design Considerations

In order to eliminate the effects of print thickness and print width variations on fired sheet resistance determinations the untrimmed resistance measurements are normalized to account for these variations. This calculation is used to determine typical as-fired sheet resistances for each resistor composition and subsequently the resistor nominal design values incorporated into product definitions. The following equation is used for this determination:

$$
R_{\text {Monsonged }}=\frac{\left(\frac{\bar{R}_{M}}{2}\right) \times \bar{T}_{D}}{T_{R}} \times \frac{W_{F}}{W_{R}}
$$

$\bar{R}_{M}=$ The Average As-Measured Resistance

$\overline{T_{D}}=$ Average Dried Thickness

$T_{R}=$ Reference Dried Thickness (20 microns)

$\overline{W_{F}}=$ Average Fired Width

$W_{R}=$ Reference Fired Width $(0.025,0.050$, or 0.100 inch $)$ 
The normalized resistance data is shown for each resistor composition in the appropriate appendix both as a percent from nominal and actual resistance.

\section{Firing Sensitivity}

Figure A-1 illustrates the untrimmed sheet resistance as a percent of the nominal sheet resistance for each resistor composition and firing profile combination. This data indicates Du Pont 2000 series resistors printed to a dried target thickness of

18-20 microns range from 10 percent below nominal to 61 percent above nominal when fired using a 30 -minute, 850 -degree $\mathrm{C}$ profile. These values shift by typically 0-10 percent (except the $10 \mathrm{~K}$ and 1-meg compositions which shift 30 and 100 percent, respectively) when fired using 825 - or 875 -degree $\mathrm{C}$ profiles.

Figure A-2 illustrates the normalized sheet resistance as a percent of the nominal sheet resistance for each resistor composition and firing profile. This data indicates Du Pont 2000 series resistors normalized to a dried target thickness of 19 microns range from

9 percent below nominal to 6 percent above nominal when fired using a 30-minute, 850-degree C profile. These values shift by typically $0-10$ percent (except the $10 \mathrm{~K}$ and 1 -meg compositions which shift 30 and 100 percent, respectively) when fired using 825- or 875-degree C profiles.

Encapsulation Effects on Untrimmed Resistance

Virtually no difference in resistance was observed between encapsulated and unencapsulated resistors for all six resistor compositions. Figures A-8, A-9, and A-10 show sensitivity to encapsulation for untrimmed resistance to be 0 to 2 percent shifts in untrimmed resistances for all compositions except $100 \mathrm{ohm}$ and $1 \mathrm{meg} \mathrm{ohm}$, which increased 5 and 10\%, respectively, after encapsulation.

\section{Thickness Sensitivity}

Appendices $\mathrm{C}$ through $\mathrm{H}$ illustrate variations in untrimmed resistances for changes in dried thickness for each resistor composition. The data shows that thickness is inversely proportional to resistance for all resistor compositions and resistances changed typically $+/-10$ to 20 percent for a 20 percent change in thickness for each resistor composition. Figure A-19 illustrates the dried thickness target range of 18 to 20 microns was maintained by printing the wet thickness within the range of 28 to 32 microns for each resistor composition.

\section{Effects of Resistor Geometry and Orientation}

Figures A-11 through A-14 illustrate untrimmed resistance as a percent from nominal for each resistor geometry and orientation combination. The geometries tested were $0.025 \mathrm{inch}, 0.050 \mathrm{inch}$, and 0.100 inch minimum resistor dimensions (resistor width), and the orientation refers to the direction of the resistor length compared to the direction of the squeegee travel. The data shows the effect of resistor orientation was negligible for each paste composition with all geometries exhibiting a spread of typically less than 15 percent between resistors parallel and perpendicular to the squeegee travel. The inherent lack of surface topography on this substrate material would contribute to this consistency. Resistor geometry, however, can be seen to have more of an effect on resistance with most paste compositions displaying a 10 - 15 percent spread between the 0.025 -inch and 0.050 -inch geometries compared to a 
15 - 25 percent spread between 0.050 -inch and 0.100 -inch resistor geometries. The larger resistor geometries tend to print thinner, resulting in higher resistances.

\section{Substrate Comparison}

Figure A-7 illustrates the comparison of Du Pont 2000 series resistor compositions printed on alumina versus LTCC substrate material. The untrimmed resistance of the Du Pont 2000 series compositions, printed on both alumina and on LTCC substrate material, averaged 29 percent from the nominal untrimmed resistance. The untrimmed resistances for the $10,100,1 \mathrm{~K}, 10 \mathrm{~K}$ and 1 meg-ohm compositions were higher on alumina than the LTCC substrate. Conversely, the untrimmed resistance for the $100 \mathrm{~K}$ composition was higher on the LTCC substrate than on alumina.

\section{Overall Printing/Firing Capability}

The within print lot variability of as-fired resistance is shown in Figures A-3 through A-6 for $0.025,0.050$, and 0.100 -inch resistors. The data presented in these figures is a composite of both parallel and perpendicular orientations. The 3 sigma limits were typically $+/-30 \%$ except for the 1 meg-ohm composition, which was $+/-40 \%$.

Resistor Series Comparisons for Untrimmed Resistances

Figure B-1 illustrates relative resistances (as a percent from nominal) for Du Pont 2000 series resistor compositions versus Du Pont 1400 series resistor compositions.

Du Pont 1400 is currently used in thick film production on aluminum oxide substrate material. Du Pont 2000 is used in LTCC production at Honeywell Federal Manufacturing \& Technologies. Du Pont 2000 series printed on alumina can be seen to be comparable to the 1400 series in terms of percent from nominal for untrimmed resistances. Du Pont 2000 series resistor compositions printed on alumina yielded fired values typically within $20 \%$ of Du Pont 1400 series printed on alumina except for 100-ohm (Du Pont 2021) and 1 meg-ohm (Du Pont 2061) which increased approximately $65-70$ percent in value.

Furnace sensitivity was found to be less with Du Pont 2000 (average resistance spread in three furnaces of 5\% for all resistor compositions) than the Du Pont 1400 (average resistance spread in three furnaces of $7 \%$ for all resistor compositions).

\section{Determination of Resistor Trimming Operating Envelope}

The resistors on twenty-four (24) samples printed with 2011 paste and covered with 5415D glaze were laser trimmed. Twenty-six (26) samples printed with 2011 resistor paste and not covered with glaze were laser trimmed. The resistors on eighteen (18) samples from each paste (2021 through 2051 ) and covered with 5415D glaze were laser trimmed. The same number of samples not covered with glaze were laser trimmed. Twenty-four samples printed with 2061 resistor paste and glaze, and twenty-four (24) samples printed with 2061 resistor paste, but no glaze were laser trimmed.

They were trimmed using various combinations of pulse rate (Qrate), bite size, and power, as shown in Tables 1 and 2. Two resistors were cut using each combination. The 0.025 -inch resistor was cut completely in half, and the 0.05 -inch resistor was cut to raise its value 1.4 times its 
original value. The 0.1 -inch resistor was left untrimmed to be used for reference. The trimming was accomplished on a General Scanning model W670 laser trim system.

Table 1

\begin{tabular}{|c|c|c|c|c|c|c|c|}
\hline \multicolumn{8}{|c|}{ EVALUATED LASER PARAMETERS (5415D GLAZE) } \\
\hline Power (mW) & \multicolumn{4}{|c|}{ Qrate } & \multicolumn{3}{|c|}{ LEGEND } \\
\hline 800 & WXYZ & WXYZ & $W X Y Z$ & $W X Y Z$ & \multirow{2}{*}{$\begin{array}{c}2011 \\
W=2 \mathrm{KHz}\end{array}$} & \multirow[t]{2}{*}{$2021-2051$} & \multirow{2}{*}{$\begin{array}{l}2061 \\
V=2 K H Z\end{array}$} \\
\hline 700 & WWXYZ & WXYZ & WWX YZ & WWX Y Z & & & \\
\hline 600 & WWXYZ & WWX Y Z & WWX Y Z & VWX Y Z & $x=3 \mathrm{KHz}$ & $X=3 K \mathrm{KHz}$ & $x=3 \mathrm{KHz}$ \\
\hline 500 & WWXYZ & WWX Y Z & WWX Y Z & VWX Y Z & $\mathrm{Y}=4 \mathrm{KHz}$ & $\mathrm{Y}=4 \mathrm{KHz}$ & $Y=4 \mathrm{KHz}$ \\
\hline 400 & WWXYZ & WWX YZ & WWX Y Z & VWX Y Z & $\mathrm{Z}=5 \mathrm{KHz}$ & $\mathrm{Z}=5 \mathrm{KHz}$ & $\mathrm{Z}=5 \mathrm{KHz}$ \\
\hline 300 & $W W \times Y Z$ & WWX Y Z & WWX Y Z & WWX Y Z & & & \\
\hline 200 & $V$ & $V$ & $V$ & $V$ & & & \\
\hline & 0.062 & 0.122 & 0.183 & 0.244 & Bite Size ( & & \\
\hline
\end{tabular}

Table 2

\begin{tabular}{|c|c|c|c|c|c|c|c|}
\hline \multicolumn{8}{|c|}{ EVALUATED LASER PARAMETERS (NO GLAZE) } \\
\hline Power (mW) & \multicolumn{4}{|c|}{ Qrate } & \multicolumn{3}{|c|}{ LEGEND } \\
\hline 800 & WXYZ & WWX YZ & $V W \times Y Z$ & WWX Y Z & 2011 & $2021-2051$ & 2061 \\
\hline 700 & WWXYZ & WXYZ & WWX Y Z & WWX Y Z & $\mathrm{W}=2 \mathrm{KHz}$ & & $\mathrm{V}=2 \mathrm{KHZ}$ \\
\hline$\overline{600}$ & WWXYZ & WWX YZ & WWX YZ & VWX Y Z & $x=3 \mathrm{KHz}$ & $\mathrm{X}=3 \mathrm{KHz}$ & $x=3 \mathrm{KHz}$ \\
\hline 500 & WWY Y & WW Y Z & WWX Y Z & VWX Y Z & $\mathrm{Y}=4 \mathrm{KHz}$ & $\mathrm{Y}=4 \mathrm{KHz}$ & $Y=4 \mathrm{KHz}$ \\
\hline 400 & WWX Y & WXYZ & $V W X Y Z$ & WWX Y Z & $\mathrm{Z}=5 \mathrm{KHz}$ & $\mathrm{Z}=5 \mathrm{KHz}$ & $\mathrm{Z}=5 \mathrm{KHz}$ \\
\hline 300 & WXY Y & WWXYZ & VWX Y Z & WWX Y Z & \multirow{4}{*}{\multicolumn{3}{|c|}{ Bite Size (mils) }} \\
\hline 200 & W & W & W & $W$ & & & \\
\hline 100 & W & W & W & W & & & \\
\hline & 0.062 & 0.122 & 0.183 & 0.244 & & & \\
\hline
\end{tabular}

The acceptable operating range of the laser was determined from these samples. The laser trims were evaluated using visual criteria, isolation resistance, and stability. Stability was determined by the tests described later in this report.

Resistor Performance Trimmed at the Operating Point

Selection of Operating Point

The selection of the operating points was determined from the operating envelopes shown in the first four figures each in Appendices I through $\mathrm{N}$.

Resistor Stability

Eighteen (18) samples from each paste decade, both glaze covered and not covered, were laser trimmed at the selected operating point. Resistor number 1 on each sample, a 25-mil wide resistor, was cut in half to obtain a more statistically accurate estimate of the isolation resistance at the operating point. The remaining 25-mil wide resistors and the 50-mil wide resistors on the samples were laser trimmed to increase their value 1.4 times their original value. A standard "L" trim was used. Tables 3 and 4 list the laser 
parameters used to trim the samples.

Table 3

\begin{tabular}{|c|c|c|c|}
\hline \multicolumn{4}{|c|}{ LASER OPERATING POINTS (5415D GLAZE) } \\
\hline \hline PASTE & QRATE (KHz) & EITE SIZE (mils) & POWER (mw) \\
\hline 2011 & 2 & 0.122 & 600 \\
\hline 2021 & 3 & 0.122 & 600 \\
\hline 2031 & 3 & 0.122 & 600 \\
\hline 2041 & 3 & 0.122 & 600 \\
\hline 2051 & 3 & 0.122 & 600 \\
\hline 2061 & 2 & 0.122 & 500 \\
\hline
\end{tabular}

Table 4

\begin{tabular}{|c|c|c|c|}
\hline \multicolumn{4}{|c|}{ LASER OPERATING POINTS (NO GLAZE) } \\
\hline \hline PASTE & QRATE (KHz) & BITE SIZE (mils) & POWER (mw) \\
\hline 2011 & 2 & 0.122 & 600 \\
\hline 2021 & 3 & 0.122 & 600 \\
\hline 2031 & 3 & 0.122 & 600 \\
\hline 2041 & 3 & 0.122 & 600 \\
\hline 2051 & 3 & 0.122 & 600 \\
\hline 2061 & 2 & 0.183 & 600 \\
\hline
\end{tabular}

The samples were tested as described later in this report. Resistor stability results for each test are shown in Appendices I through $\mathrm{N}$. The data shown in Tables 5 and 6 is the change in resistance after all tests for the 25-mil and 50 mil wide resistors.

Table 5

\begin{tabular}{|c|c|c|c|c|c|c|}
\hline \multicolumn{7}{|c|}{ STAEILITY FOR RESISTORS TRIMMED AT THE OPERATING POINT (5415D GLAZE) } \\
\hline \multirow[t]{4}{*}{ Paste } & \multicolumn{6}{|c|}{ Resistor Width (mils) } \\
\hline & \multicolumn{3}{|c|}{25} & \multicolumn{3}{|c|}{50} \\
\hline & \multicolumn{6}{|c|}{$\%$ Change In Resistance After All Tests } \\
\hline & Average & Low & High & Average & Low & High \\
\hline 2011 & 0.525 & 0.342 & 0.777 & 0.394 & 0.250 & 0.618 \\
\hline 2021 & 0.140 & 0.037 & 0.373 & 0.094 & 0.017 & 0.162 \\
\hline 2031 & 0.101 & -0.040 & 0.200 & 0.083 & -0.013 & 0.159 \\
\hline 2041 & 0.124 & -0.106 & 0.289 & 0.068 & -0.063 & 0.284 \\
\hline 2051 & 0.103 & -0.098 & 0.275 & 0.075 & -0.057 & 0.177 \\
\hline 2061 & 0.111 & -0.437 & 0.506 & 0.219 & -0.161 & 0.610 \\
\hline
\end{tabular}

Table 6 


\begin{tabular}{|c|c|c|c|c|c|c|}
\hline \multicolumn{7}{|c|}{ STABILITY FOR RESISTORS TRIMMED AT THE OPERATING POINT (NO GLAZE) } \\
\hline \multirow[t]{4}{*}{ Paste } & \multicolumn{6}{|c|}{ Resistor Width (mils) } \\
\hline & \multicolumn{3}{|c|}{25} & \multicolumn{3}{|c|}{50} \\
\hline & \multicolumn{6}{|c|}{$\%$ Change In Resistance After All Tests } \\
\hline & Average & Low & High & Average & Low & High \\
\hline 2011 & 0.568 & 0.436 & 0.756 & 0.526 & 0.414 & 0.926 \\
\hline 2021 & 0.151 & 0.015 & 0.332 & 0.122 & 0.031 & 0.229 \\
\hline 2031 & 0.115 & -0.040 & 0.328 & 0.086 & -0.032 & 0.278 \\
\hline 2041 & 0.140 & -0.028 & 0.394 & 0.124 & -0.060 & 0.236 \\
\hline 2051 & -0.053 & -0.452 & 1.039 & -0.049 & -0.325 & 0.194 \\
\hline 2061 & 0.105 & -0.165 & 0.429 & 0.339 & -0.097 & 0.965 \\
\hline
\end{tabular}

\section{Resistor Tolerance}

The recommended resistor tolerance was derived from the data generated from this evaluation. Three factors were used to arrive at these recommendations: how close to the target value the laser trim system was able to trim the resistors, the percent change in resistance after all tests, and the average percent change in resistance of the samples after all tests. To normalize the distribution, the average percent change in resistance was subtracted from the percent change in resistance for each sample. The results are shown in the figures in Appendices I through $\mathrm{N}$ and Tables 7 and 8.

Table 7

\begin{tabular}{|c|c|c|}
\hline \multicolumn{3}{|c|}{ RECOMMENDED TOLERANCE (5415D GLAZE) } \\
\hline \hline \multirow{2}{*}{ Paste } & \multicolumn{2}{|c|}{ Resist or Width (mils) } \\
\hline & 25 & 50 \\
\cline { 2 - 3 } & \multicolumn{2}{|c|}{ TOLERANCE $(+/-\%)$} \\
\hline 2011 & 1.6 & 1.2 \\
\hline 2021 & 1.2 & 1.0 \\
\hline 2031 & 1.2 & 1.0 \\
\hline 2041 & 1.2 & 1.0 \\
\hline 2051 & 1.0 & 1.0 \\
\hline 2061 & 2.0 & 2.0 \\
\hline
\end{tabular}

Table 8

\begin{tabular}{|c|c|c|}
\hline \multicolumn{2}{|c|}{ RECOMMENDED TOLERANCE (NO GLAZE) } \\
\hline \hline \multirow{2}{*}{ Paste } & \multicolumn{2}{|c|}{ Resist or Width (mils) } \\
\hline & 25 & 50 \\
\cline { 2 - 3 } & \multicolumn{2}{|c|}{ TOLERANCE $(+/-\%)$} \\
\hline 2011 & 1.5 & 1.5 \\
\hline 2021 & 1.2 & 1.0 \\
\hline 2031 & 1.0 & 1.0 \\
\hline 2041 & 1.2 & 1.0 \\
\hline 2051 & 2.0 & 1.0 \\
\hline 2061 & 2.0 & 2.0 \\
\hline
\end{tabular}


The recommended resistor tolerance was derived by multiplying the distribution shown in the figures by approximately four. This factor is recommended by Quality Engineering to account for uncertainties.

\section{Temperature Coefficient of Resistance (TCR)}

One sample from each paste decade was selected for TCR testing. A 50-mil trimmed resistor on each sample was selected. The results shown in Table 9 are for unglazed samples. The results shown in Table 10 are for samples covered with the 5415D glaze. The test is described in a later section in this report.

Table 9

\begin{tabular}{|c|c|c|c|c|c|}
\hline \multicolumn{6}{|c|}{ UNGLAZED } \\
\hline \multirow[t]{2}{*}{ PASTE } & \multicolumn{3}{|c|}{ RESISTANCE (Ohms) @ TEMPERA TURE } & \multicolumn{2}{|c|}{$\mathrm{TCR}\left(\mathrm{ppm} /{ }^{\circ} \mathrm{C}\right)$} \\
\hline & "R@25" & 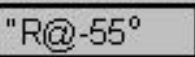 & "R@125" & TCR $@-55^{\circ}$ & TCR $@ 125^{\circ}$ \\
\hline Ohms & 34.853 & 34.913 & 34.926 & -21.519 & 20.945 \\
\hline 2021 K Ohms & 480.360 & 485.517 & 478.237 & -134.196 & -44.196 \\
\hline 2031 K Ohms & 3.758 & 3.744 & 3.778 & 46.567 & 53.220 \\
\hline 2041 K Ohms & 42.200 & 42.425 & 42.228 & -66.647 & 6.635 \\
\hline 2051 KOhms & 278.123 & 279.724 & 278.485 & -71.956 & 13.016 \\
\hline 2061 M Ohms & 4.365 & 4.4 & 4.367 & -100.229 & 4.582 \\
\hline Specific ation ${ }^{*}$ & & & & $>-75$ & $<50$ \\
\hline
\end{tabular}

\section{*Du Pont}

It can be seen in the table above that the hot TCR performance of the 2031 and the cold TCR performance of 2021 and 2061 samples does not correspond to the performance listed by Du Pont on their technical data sheet. ${ }^{2}$

Table 10

\begin{tabular}{|c|c|c|c|c|c|}
\hline \multicolumn{6}{|c|}{ GLAZED } \\
\hline \multirow[t]{2}{*}{ PASTE } & \multicolumn{3}{|c|}{ RESISTANCE (Ohms) @ TEMPERA TURE } & \multicolumn{2}{|c|}{$\mathrm{TCR}\left(\mathrm{ppm} /{ }^{\circ} \mathrm{C}\right)$} \\
\hline & "R@25" & 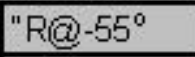 & "R@125 & TCR $@-55^{\circ}$ & TCR $@ 125^{\circ}$ \\
\hline Ohms & 36.670 & 36.836 & 36.781 & -56.586 & 30.270 \\
\hline 2021 K Ohms & 435.740 & 440.127 & 433.877 & -125.840 & -42.763 \\
\hline 2031 K Ohms & 3.645 & 3.629 & 3.670 & 56.013 & 68.587 \\
\hline 2041 K Ohms & 29.256 & 29.318 & 29.378 & -26.348 & 41.701 \\
\hline 2051 KOhms & 252.910 & 253.877 & 253.900 & -47.777 & 39.144 \\
\hline 2061 M Ohms & 4.487 & 4.521 & 4.488 & -93.789 & 2.229 \\
\hline Specification ${ }^{*}$ & & & & $>-75$ & $<50$ \\
\hline
\end{tabular}

\section{*Du Pont}

As was the case with the unglazed sample, it can bee seen that the hot TCR performance of the 2031 and the cold TCR performance of 2021 and 2061 samples does not correspond to the performance listed by Du Pont on their technical data sheet. ${ }^{2}$ 
The resistor values on all samples, trimmed and untrimmed, were measured on a General Scanning W670 laser trim system within a few seconds of having been laser trimmed. This measurement will hereafter be referred to as $\mathrm{T} \varnothing$.

The samples were subjected to the following tests.

\section{4-Hour Drift}

The samples were re-measured again approximately 24 hours later, and the change in resistance was calculated. This was done to determine the ability to repeatably measure them and to obtain some measure of their off-the-shelf stability. In past studies of other resistor pastes, the largest change in resistance typically occurred during the first 24 hours.

\section{Temperature Shock}

Each sample was then subjected to a solder pot shock test. This test involved placing each test sample individually on molten solder heated to approximately $268^{\circ} \mathrm{C}$ for

15 seconds. The sample was removed and placed on a stainless steel tabletop at approximately $25^{\circ} \mathrm{C}$ and allowed to cool. All of the resistors were re-measured, and the change in resistance compared to $\mathrm{T} \varnothing$ was calculated.

\section{Temperature Cycle}

The test samples were then subjected to a temperature cycle test. The test apparatus consisted of two interconnected test chambers. One chamber was set to $-50^{\circ} \mathrm{C}$ while the other was set to $125^{\circ} \mathrm{C}$. A cycle consisted of moving the test samples from one chamber to the other and then back. The approximate transport time was five seconds. The samples were held at each temperature extreme a minimum of 15 minutes. Upon completion of this test, the resistors were again measured, and the change from $\mathrm{T} \varnothing$ was calculated.

\section{Life Test}

The samples were subjected to the 1000-hour aging test. The samples were placed in an oven heated to $150^{\circ} \mathrm{C}$. At intervals of 200,600 , and 1000 hours the samples were removed from the oven and allowed to cool to room temperature. The resistors were measured, and the change compared to $\mathrm{T} \varnothing$ was calculated.

The results of each of the tests are shown in the graphs in the appendices at the end of this report. The results are arranged by paste decade in Appendices I through $\mathrm{N}$.

\section{Temperature Coefficient of Resistance}

The TCR test involved measuring the resistors at $25^{\circ} \mathrm{C}$. The samples were then cooled to $-55^{\circ} \mathrm{C}$ and allowed to stabilize at that temperature for approximately 30 minutes. The resistors were measured at this temperature. The samples were then heated to $125^{\circ} \mathrm{C}$ and allowed to stabilize at this temperature for approximately 30 minutes. The resistors were measured while at this temperature. The following formulas were used. 
hot $\operatorname{TCR}\left(\mathrm{ppm} /{ }^{o} \mathrm{C}\right)=\frac{R_{125^{\circ}}-R_{25}}{R_{25}} \times 10,000$

cold $\operatorname{TCR}\left(p p m /{ }^{o} \mathrm{C}\right)=\frac{\left(R-55^{\circ}\right)-R_{25^{\circ}}}{R_{25}} \times(-12,500)$.

These temperatures were used so that results could be correlated to Du Pont's test procedures and published results. $^{2-3}$

\section{Resistor Trim Requirements}

Two main requirements were used when considering the ability of a combination of laser parameters to make an acceptable trim. They were visual requirements and isolation resistance.

Visual (Viewed at 30X Magnification)

- Laser kerf free of obvious debris.

- Laser kerf free of bridges (continuous laser kerf).

- No continuous grooving of the substrate material in the kerf.

- The width of reflowed resistor material on either side of the kerf shall be less than the kerf width.

\section{Isolation Resistance}

Isolation resistance is the value of the resistor that has been cut completely in half. Depending upon the combination of laser parameters selected and the resistor material, the value of the isolation resistance will range from the design value of the resistor to some greater value (typically greater than 32 meg-ohms).

As the combination of laser parameters is adjusted to cause increasing energy to be applied to the resistor, the value of the isolation resistance increases from a minimum to some larger value. Increasing laser energy cuts deeper into the resistor. At some value of laser energy, the resistor material is removed completely from the laser kerf, and there is a several orders of magnitude increase in resistance. This is the minimum laser energy considered sufficient to trim resistors.

\section{Application of Requirements}

The lower end of the operating envelope is determined by the combination of laser parameters that result in the minimum energy necessary to produce an isolated trim and meet the visual requirements for kerf cleanliness.

The upper end of the operating envelope is determined by the combination of laser parameters that result in the maximum energy that can produce laser trims that meet all the visual requirements and isolation resistance.

The operating envelopes are shown in the first four figures in each appendix. The envelope is based on meeting all visual requirements and isolation resistance greater than $32 \mathrm{meg}$-ohms. Also shown in these 
figures is the change in resistance (stability) after all tests for all combinations of laser parameters evaluated

Resistivity Specific Data and Observations

10-Ohm (Du Pont 2011)

Refer to Appendices A, B, and C for untrimmed resistor data and Appendix I for trimmed resistor data.

- Average untrimmed resistance was centered $22 \%$ above nominal for 50-mil geometries when fired using the 850-degree C - 30-minute profile. Average normalized resistance was centered $9 \%$ above nominal.

- Composite print lot variability (+/- 3 sigma for all geometries and orientations) ranged from $-20 \%$ to $+54 \%$ from nominal.

- Firing sensitivity tests yielded untrimmed resistances as follows: $40 \%$ above nominal for 825-degree $\mathrm{C}$ firing, $19 \%$ above nominal for 850 -degree $\mathrm{C}$ firing, and $25 \%$ above nominal for 875-degree $\mathrm{C}$ firing.

- Sensitivity to encapsulation was found to be nonexistent with a $-3 \%$ to $+3 \%$ shift in untrimmed resistances for all resistor geometries.

- Thickness sensitivity indicated a +/- 20\% shift in resistances between a dried thickness of 19 microns and 23 or 16 microns.

- The target wet print thickness for Du Pont 2011 is 28 microns yielding a dried thickness of 19 microns.

- Resistance sensitivity to substrate material when comparing Du Pont 951 LTCC and $\mathrm{AlO}_{2}$ indicated a $15 \%$ increase for resistors printed on alumina substrates.

- Resistances were affected by resistor geometry as follows: 25-mil resistors were approximately nominal value; 50- and 100-mil resistors were $18 \%$ and $39 \%$ above nominal, respectively.

- Resistances were affected by orientation as follows: resistors parallel to squeegee travel were 5-10\% lower than resistors perpendicular to squeegee travel.

- Furnace sensitivity tests indicated a 5-10\% spread in untrimmed resistances between parts fired at 850 degrees $\mathrm{C}$ in the three production thick film furnaces.

- Resistance comparison between the 10-ohm Du Pont 1400 (1610) series resistor composition printed on alumina and the 10-ohm Du Pont 2000 (2011) series resistor composition printed on alumina demonstrated Du Pont 2011 averaged 18.7\% above nominal compared to Du Pont 1610 which averaged 6\% above nominal. Furnace sensitivity comparisons for Du Pont 1610 and 2011 showed 2-8\% spread between furnaces for each material.

- There is a larger operating envelope for unglazed; however, the envelope at $2 \mathrm{kHz}$ is similar for both glazed and unglazed.

- The same operating point was selected to trim glazed and unglazed resistors because the operating envelopes were similar.

- Glazed samples trimmed at the operating point were slightly more stable through the tests.

- A resistor tolerance of $\pm 1.6 \%$ is possible for 25 -mil wide resistors and $\pm 1.2 \%$ is possible for 50 -mil wide resistors for glazed samples. A resistor tolerance of $\pm 1.5 \%$ is possible for 25 -mil wide resistors and \pm

$1.5 \%$ is possible for 50 -mil wide resistors for unglazed samples. Highest yield would be with resistors wider than 25 mils. 
This conclusion is based on the data in Figures I-17 through I-20. The data shown is the distribution of the percent from target value each resistor was after trimming and after all tests. The average of the percent from target value was subtracted from each value to normalize the distribution. The tolerance recommendation is obtained by multiplying the distribution by 4 , i.e., $4 X \approx \pm 0.25 \%= \pm 1 \%$ for the 50 mil wide resistors. This guidance is provided by the Quality Division and is used to account for uncertainties and improve confidence in the recommendations.

- TCR performance is within the range published by Du Pont.

\section{0-Ohm (Du Pont 2021)}

Refer to Appendices A, B, and D for untrimmed resistor data and Appendix J for trimmed resistor data.

- Average untrimmed resistance was centered 57\% above nominal for 50-mil geometries when fired using the 850-degree C - 30-minute profile. Average normalized resistance was centered 57\% above nominal.

- Composite print lot variability (+/- 3 sigma for all geometries and orientations) ranged from $+4 \%$ to $+105 \%$ from nominal.

- Firing sensitivity tests yielded untrimmed resistances as follows: $57 \%$ above nominal for 825-degree $\mathrm{C}$ firing, $57 \%$ above nominal for 850-degree $\mathrm{C}$ firing, and $63 \%$ above nominal for 875-degree $\mathrm{C}$ firing.

- Sensitivity to encapsulation was found to be nonexistent with a $+5 \%$ shift in untrimmed resistances for all resistor geometries.

- Thickness sensitivity indicated a +/- 25\% shift in resistances between a dried thickness of 19 microns and 23 or 16 microns.

- The target wet print thickness for Du Pont 2021 is 28 microns yielding a dried thickness of 19 microns.

- Resistance sensitivity to substrate material when comparing Du Pont 951 LTCC and $\mathrm{AlO}_{2}$ indicated an $86 \%$ increase for resistors printed on alumina substrates.

- Resistances were affected by resistor geometry as follows: 25 -mil resistors were $30 \%$ above nominal value; 50 - and 100-mil resistors were $60 \%$ and $75 \%$ above nominal, respectively.

- Resistances were affected by orientation as follows: resistors parallel to squeegee travel were 9-15\% lower than resistors perpendicular to squeegee travel.

- Furnace sensitivity tests indicated a 3-5\% spread in untrimmed resistances between parts fired at 850 degrees $\mathrm{C}$ in the three production thick film furnaces.

- Resistance comparison between the 100-ohm Du Pont 1400 (1421) series resistor composition printed on alumina and the 100-ohm Du Pont 2000 (2021) series resistor composition printed on alumina demonstrated Du Pont 2021 averaged 54\% above nominal compared to Du Pont 1421 which averaged 23\% below nominal. Furnace sensitivity comparisons for Du Pont 1421 and 2021 showed 5-10\% spread between furnaces for each material.

- There is a larger operating envelope for unglazed samples.

- The same operating point was selected for both.

- Glazed and unglazed samples trimmed at the operating point responded to stability testing in a similar manner. Both were stable, with the 25-mil wide resistors slightly less stable than the 50-mil wide resistors.

- A resistor tolerance of $\pm 1.2 \%$ is possible for 25 -mil wide resistors and \pm

$1.0 \%$ is possible for 50 -mil wide resistors for glazed and unglazed samples. Highest yield would be with resistors wider than 25 mils. 
This conclusion is based on the data in Figures J-15 through J-18. The data shown is the distribution of the percent from target value each resistor was after trimming and after all tests. The average of the percent from target value was subtracted from each value to normalize the distribution. The tolerance recommendation is obtained by multiplying the distribution by 4 , i.e., $4 X \approx \pm 0.25 \%= \pm 1 \%$ for the 50-mil wide resistors. This guidance is provided by the Quality Division and is used to account for uncertainties and improve confidence in the recommendations.

- TCR performance, glazed and unglazed, is within the specification published by Du Pont at the hot temperature. TCR performance at the cold temperature, for glazed and unglazed, is not within the value published by Du Pont.

1K-Ohm (Du Pont 2031)

Refer to Appendices A, B, and E for untrimmed resistor data and Appendix K for trimmed resistor data.

$\bullet$

- Average untrimmed resistance was centered $27 \%$ above nominal for 50-mil geometries when fired using the 850-degree C - 30-minute profile. Average normalized resistance was centered 19\% above nominal.

- Composite print lot variability (+/- 3 sigma for all geometries and orientations) ranged from nominal to $+51 \%$ from nominal.

- Firing sensitivity tests yielded untrimmed resistances as follows: $18 \%$ above nominal for 825-degree $\mathrm{C}$ firing, $27 \%$ above nominal for 850 -degree $\mathrm{C}$ firing, and $34 \%$ above nominal for 875-degree $\mathrm{C}$ firing.

- Sensitivity to encapsulation was found to be nonexistent with a $+1 \%$ shift in untrimmed resistances for all resistor geometries.

- Thickness sensitivity indicated a +/- 15\% shift in resistances between a dried thickness of 19 microns and 23 or 16 microns.

- The target wet print thickness for Du Pont 2031 is 28 microns yielding a dried thickness of 19 microns.

- Resistance sensitivity to substrate material when comparing Du Pont 951 LTCC and $\mathrm{AlO}_{2}$ indicated a $35 \%$ increase for resistors printed on alumina substrates.

- Resistances were affected by resistor geometry as follows: 25-mil resistors were $10 \%$ above nominal value; 50- and 100-mil resistors were $30 \%$ and $38 \%$ above nominal, respectively.

- Resistances were affected by orientation as follows: resistors parallel to squeegee travel were $2-5 \%$ lower than resistors perpendicular to squeegee travel.

- Furnace sensitivity tests indicated a 4-5\% spread in untrimmed resistances between parts fired at 850 degrees $\mathrm{C}$ in the three production thick film furnaces.

- Resistance comparison between the 1K-ohm Du Pont 1400 (1431) series resistor composition printed on alumina and the $1 \mathrm{~K}$-ohm Du Pont 2000 (2031) series resistor composition printed on alumina Du Pont 2031 averaged 27\% above nominal compared to Du Pont 1431 which averaged 5\% above nominal. Furnace sensitivity comparisons for Du Pont 1431 and 2031 showed 5\% spread between furnaces for each material.

- There is a larger operating envelope for unglazed samples.

- The same operating point was selected for both.

- Glazed and unglazed samples trimmed at the operating point responded to stability testing in a similar manner; however, glazed samples were slightly more stable. The 50-mil wide resistors on 
both glazed and unglazed samples were more stable than the 25-mil wide resistors.

- A resistor tolerance of $\pm 1.2 \%$ is possible for 25 -mil wide resistors and $\pm 1.0 \%$ is possible for 50-mil wide resistors for glazed samples. A tolerance of \pm

$1.0 \%$ is possible for both 25 - and 50-mil wide resistors on unglazed samples. Highest yield would be with resistors wider than 25 mils.

This conclusion is based on the data in Figures K-15 through K-18. The data shown is the distribution of the percent from target value each resistor was after trimming and after all tests. The average of the percent from target value was subtracted from each value to normalize the distribution. The tolerance recommendation is obtained by multiplying the distribution by 4 , i.e., $4 X \approx \pm 0.25 \%= \pm 1 \%$ for the 50 -mil wide resistors. This guidance is provided by the Quality Division and is used to account for uncertainties and improve confidence in the recommendations.

- TCR performance, glazed and unglazed, was not within the specification published by Du Pont at the hot temperature. TCR performance at the cold temperature, for glazed and unglazed, is within the value published by Du Pont.

10K-Ohm (Du Pont 2041)

Refer to Appendices A, B, and F for untrimmed resistor data and Appendix L for trimmed resistor data.

- Average untrimmed resistance was centered $11 \%$ above nominal for 50-mil geometries when fired using the 850-degree C - 30-minute profile. Average normalized resistance was centered $3 \%$ above nominal.

- Composite print lot variability (+/- 3 sigma for all geometries and orientations) ranged from $23 \%$ below nominal to $20 \%$ above nominal.

- Firing sensitivity tests yielded untrimmed resistances as follows: $40 \%$ above nominal for 825-degree $\mathrm{C}$ firing, $11 \%$ above nominal for 850-degree $\mathrm{C}$ firing, and $9 \%$ below nominal for 875-degree $\mathrm{C}$ firing.

- Sensitivity to encapsulation was found to be nonexistent with a $-2 \%$ shift in untrimmed resistances for all resistor geometries.

- Thickness sensitivity indicated a +/- 7\% shift in resistances between a dried thickness of 19 microns and 23 or 16 microns.

- The target wet print thickness for Du Pont 2041 is 29 microns yielding a dried thickness of 19 microns.

- Resistance sensitivity to substrate material when comparing Du Pont 951 LTCC and $\mathrm{AlO}_{2}$ indicated a $26 \%$ increase for resistors printed on alumina substrates.

- Resistances were affected by resistor geometry as follows: 25-mil resistors were 4\% below nominal value; 50- and 100-mil resistors were $7 \%$ and $12 \%$ above nominal, respectively.

- Resistances were affected by orientation as follows: resistors parallel to squeegee travel were 2-3\% lower than resistors perpendicular to squeegee travel.

- Furnace sensitivity tests indicated a 6-9\% spread in untrimmed resistances between parts fired at 850 degrees $\mathrm{C}$ in the three production thick film furnaces.

- Resistance comparison between the 10K-ohm Du Pont 1400 (1441) series resistor composition printed on alumina and the 10K-ohm Du Pont 2000 (2041) series resistor composition printed on alumina demonstrated Du Pont 2041 averaged 6\% above nominal compared to Du Pont 1441 which averaged 13\% above nominal. Furnace sensitivity comparisons for Du Pont 1441 and 2041 
showed 4-7\% spread between furnaces for each material.

- There is a larger operating envelope for unglazed samples.

- The same operating point was selected for both.

- Glazed and unglazed samples trimmed at the operating point responded to stability testing in a similar manner; however, glazed samples were slightly more stable. The 50-mil wide resistors on both glazed and unglazed samples were more stable than the 25 -mil wide resistors.

- A resistor tolerance of $\pm 1.2 \%$ is possible for 25 -mil wide resistors and \pm

$1.0 \%$ is possible for 50-mil wide resistors for glazed and unglazed samples. Highest yield would be with resistors wider than 25 mils.

This conclusion is based on the data in Figures L-15 through L-18. The data shown is the distribution of the percent from target value each resistor was after trimming and after all tests. The average of the percent from target value was subtracted from each value to normalize the distribution. The tolerance recommendation is obtained by multiplying the distribution by 4 , i.e., $4 X \approx \pm 0.25 \%= \pm 1 \%$ for the 50-mil wide resistors. This guidance is provided by the Quality Division and is used to account for uncertainties and improve confidence in the recommendations.

- TCR performance, glazed and unglazed, is within the specification published by Du Pont at the hot and cold temperatures.

100K-Ohm (Du Pont 2051)

Refer to Appendices A, B, and $\mathrm{G}$ for untrimmed resistor data and Appendix $\mathrm{M}$ for trimmed resistor data.

- Average untrimmed resistance was centered $8 \%$ above nominal for 50-mil geometries when fired using the 850-degree C - 30-minute profile. Average normalized resistance was centered $8 \%$ above nominal.

- Composite print lot variability (+/- 3 sigma for all geometries and orientations) ranged from $41 \%$ below nominal to $8 \%$ above nominal.

- Firing sensitivity tests yielded untrimmed resistances as follows: $11 \%$ below nominal for 825-degree $\mathrm{C}$ firing, $10 \%$ below nominal for 850-degree $\mathrm{C}$ firing, and 875-degree $\mathrm{C}$ firing.

- Sensitivity to encapsulation was found to be nonexistent with a $-2 \%$ shift in untrimmed resistances for all resistor geometries.

- Thickness sensitivity indicated a +/- 12\% shift in resistances between a dried thickness of 19 microns and 23 or 16 microns.

- The target wet print thickness for Du Pont 2051 is 28 microns yielding a dried thickness of 19 microns.

- Resistance sensitivity to substrate material when comparing Du Pont 951 LTCC and $\mathrm{AlO}_{2}$ indicated an $80 \%$ decrease for resistors printed on alumina substrates.

- Resistances were affected by resistor geometry as follows: 25- mil resistors were $20 \%$ below nominal value; 50 - and 100-mil resistors were $6 \%$ below and $12 \%$ above nominal, respectively.

- Resistances were affected by orientation as follows: resistors parallel to squeegee travel were $5-10 \%$ lower than resistors perpendicular to squeegee travel.

- Furnace sensitivity tests indicated a 1-2\% spread in untrimmed resistances between parts fired at 850 degrees $\mathrm{C}$ in the three production thick film furnaces.

- Resistance comparison between the 100K-ohm Du Pont 1400 (1451) series resistor composition printed on alumina and the 100K-ohm Du Pont 2000 (2051) series resistor composition printed on alumina demonstrated Du Pont 2051 averaged 9\% below nominal compared to Du Pont 1451 which averaged 23\% above nominal. Furnace sensitivity comparisons for Du Pont 1451 and 2051 
showed $1-7 \%$ spread between furnaces for each material.

- The operating envelope for the glazed samples is extremely small compared to the envelope for the unglazed samples.

- The same operating point was selected for both.

- Glazed samples, trimmed at the operating point, were more stable than the unglazed samples. The 50-mil wide resistors on both glazed and unglazed samples were more stable than the 25-mil wide resistors.

- A resistor tolerance of $\pm 1.0 \%$ is possible for 25 -mil wide and for 50-mil wide resistors for glazed samples. A resistor tolerance of $\pm 2.0 \%$ is possible with unglazed, 25-mil wide resistors, and a tolerance of \pm

- $1.0 \%$ is possible for the 50-mil wide unglazed resistors. For both glazed and unglazed samples the highest yield would be with resistors wider than 25 mils.

This conclusion is based on the data in Figures M-15 through M-18. The data shown is the distribution of the percent from target value each resistor was after trimming and after all tests. The average of the percent from target value was subtracted from each value to normalize the distribution. The tolerance recommendation is obtained by multiplying the distribution by 4 , i.e., $4 X \approx \pm 0.25 \%= \pm 1 \%$ for the 50-mil wide resistors. This guidance is provided by the Quality Division and is used to account for uncertainties and improve confidence in the recommendations.

- TCR performance, glazed and unglazed, is within the specification published by Du Pont at the hot and cold temperatures.

1Meg-Ohm (Du Pont 2061)

Refer to Appendices A, B, and $\mathrm{H}$ for untrimmed resistor data and Appendix $\mathrm{N}$ for trimmed resistor data.

- Average untrimmed resistance was centered $45 \%$ above nominal for 50-mil geometries when fired using the 850-degree C - 30-minute profile. Average normalized resistance was centered $45 \%$ above nominal.

- Composite print lot variability (+/- 3 sigma for all geometries and orientations) ranged from $7 \%$ above nominal to $89 \%$ above nominal.

- Firing sensitivity tests yielded untrimmed resistances as follows: $152 \%$ above nominal for 825-degree $\mathrm{C}$ firing, 52\% above nominal for 850-degree $\mathrm{C}$ firing, and $74 \%$ above nominal for 875-degree $\mathrm{C}$ firing.

- Sensitivity to encapsulation was found to be nonexistent with a $+9 \%$ shift in untrimmed resistances for all resistor geometries.

- Thickness sensitivity indicated a +/- 24\% shift in resistances between a dried thickness of 19 microns and 23 or 16 microns.

- The target wet print thickness for Du Pont 2061 is 32 microns yielding a dried thickness of 19 microns.

- Resistance sensitivity to substrate material when comparing Du Pont 951 LTCC and $\mathrm{AlO}_{2}$ indicated an $80 \%$ increase for resistors printed on alumina substrates.

- Resistances were affected by resistor geometry as follows: 25 -mil resistors were $25 \%$ above nominal value; 50 - and 100-mil resistors were $50 \%$ below and $63 \%$ above nominal, respectively.

- Resistances were affected by orientation as follows: resistors parallel to squeegee travel were $2-5 \%$ lower than resistors perpendicular to squeegee travel. 
- Furnace sensitivity tests indicated a 3-5\% spread in untrimmed resistances between parts fired at 850 degrees $\mathrm{C}$ in the three production thick film furnaces.

- Resistance comparison between the $1 \mathrm{meg}$-ohm Du Pont 1400 (1461) series resistor composition printed on alumina and the 1meg-ohm Du Pont 2000 (2061) series resistor composition printed on alumina demonstrated Du Pont 2061 averaged 46\% above nominal compared to Du Pont 1451 which averaged $20 \%$ above nominal. Furnace sensitivity comparisons for Du Pont 1461 showed 2-12\% spread between furnaces compared to a 3-5\% spread for Du Pont 2061.

- The operating envelope for the glazed and unglazed samples is similar.

- The same operating point was selected to trim glazed and unglazed resistors because the operating envelopes were similar.

- Glazed samples, trimmed at the operating point, were slightly more stable than the unglazed samples. The 50-mil wide resistors on both glazed and unglazed samples were more stable than the 25-mil wide resistors.

- A resistor tolerance of \pm

$2.0 \%$ is possible for 25-mil wide and for 50-mil wide resistors for glazed and unglazed samples For both glazed and unglazed samples the highest yield would be with resistors wider than 25 mils.

This conclusion is based on the data in Figures N-17 through N-20. The data shown is the distribution of the percent from target value each resistor was after trimming and after all tests. The average of the percent from target value was subtracted from each value to normalize the distribution. The tolerance recommendation is obtained by multiplying the distribution by 4 , i.e., $4 X \approx \pm 0.25 \%= \pm 1 \%$ for the 50-mil wide resistors. This guidance is provided by the Quality Division and is used to account for uncertainties and improve confidence in the recommendations.

- Cold TCR performance, glazed and unglazed, is not within the value published by Du Pont.

Accomplishments

This evaluation has established the following:

- Target print thicknesses and sintering process parameters consistent with the manufacturer's recommendations and compatible with Honeywell manufacturing processes for the six (6) Du Pont 2000 series resistor compositions.

- Thick film resistor physical design requirements for applications utilizing Du Pont 2000 series resistor compositions printed on alumina substrate material.

- Resistor encapsulation is not required to improve resistor stability; however, it may be used as a mechanical protectant.

- Characterization of laser trimmed resistor performance using Du Pont 2011 through 2061 resistor pastes printed on $96 \%$ alumina using Du Pont 4596 platinum/gold conductors.

- Resistor stability, for laser trimmed resistors, defined for each resistor paste.

- Definition of resistor stability allowed recommended resistor tolerances to be calculated for each paste.

- Definition of TCR performance.

The results of this evaluation indicate Du Pont 2000 series resistors can be used to fabricate integral thick film resistors applied to alumina substrates with similar functional characteristics to existing production thick film production technology. Specific recommendations for implementation of Du Pont 
2000 series resistors printed on alumina are as follows:

- Standard thick film resistor design criteria per DG10172 should be employed for resistors fabricated from Du Pont 2000 series resistors.

- To allow the tightest resistor tolerance, greatest stability, and highest yield, the minimum resistor dimension should be greater than 25 mils.

- Tight control of the printed thickness of resistors fabricated using 2011 must be exercised to allow high yields at resistor trimming.

- Use of Du Pont 2000 series resistor paste is a carcinogen-free alternative to the use of Du Pont 1400 series resistor paste on $96 \%$ alumina substrates using

Du Pont 4596 platinum/gold conductors.

The benefits of developing this capability are as follows:

- Ultimate elimination of existing carcinogenic resistor production materials, specifically Du Pont 1400 series resistor compositions and Du Pont 9137 Encapsulant Composition.

- Potentially higher production yields and reduced equipment setup times resulting from less process sensitivity of resistor fabrication materials.

- Simplification of material control and production operations by using one common resistor material for both thick film and LTCC resistor fabrication.

- Developed an alternative capability for production thick film resistor fabrication at FM\&T before product availability becomes an issue as a result of low volume sales of the Du Pont 1400 series resistors by Du Pont.

Future Work

Future work to be done to maintain state-of-the-art thick film capability will include:

- Establishment of weekly resistor process monitors for Du Pont 2000 series resistor compositions similar to the process monitors used to verify process consistency with Du Pont 1400 series resistor compositions.

- Verification of resistor stability of Du Pont 2000 series resistors by monitoring the long-term resistance variations will also be established.

Future work to be done to maintain state-of-the-art LTCC capability will include:

- Evaluation of thick film resistors buried within the monolithic substrate structure of LTCC products.

- Evaluation of Du Pont 2000 series resistors for use as post-fired thick film resistors for LTCC materials not in use presently at FM\&T.

Future work to be done to develop additional capabilities will include evaluating the compatibility of Du Pont 2000 series resistors with:

- Different thick film processes and materials not in use at FM\&T.

- Applications involving different product configurations using both new and existing materials.

- Applications employing mixed technologies such as thin film and thick film or thin film and LTCC. 


\section{References}

1R. Draudt, H. Sawhill, Post Fired 2000 Series Resistor Evaluation on 951 Green Tape, SSR:E145, Du Pont Electronic Materials Division, Ceramic Circuit Materials and Technologies Department, May 9, 1995.

2Resistor Test Method G1.5.5, E. I. Du Pont De Nemours \& Co. (Inc.), Photo Products Department, Electronic Materials Division, Wilmington, De., 19898.

3Birox ${ }^{\circledR}$ 2000-Series Resistors Technical Data Sheet, Du Pont Electronics, Wilmington, De., $10 / 94$.

APPENDIX A

SUMMARY DATA FOR UNTRIMMED DU PONT 2000 RESISTOR SERIES PRINTED ON ALUMINA 


\section{UNTRIMMED SHEET RESISTANCE - DUPONT 2000 SERIES}

Firing Sensiti vity - Printed on Alu mina (Encapsul $\mathbf{A}$ ed)

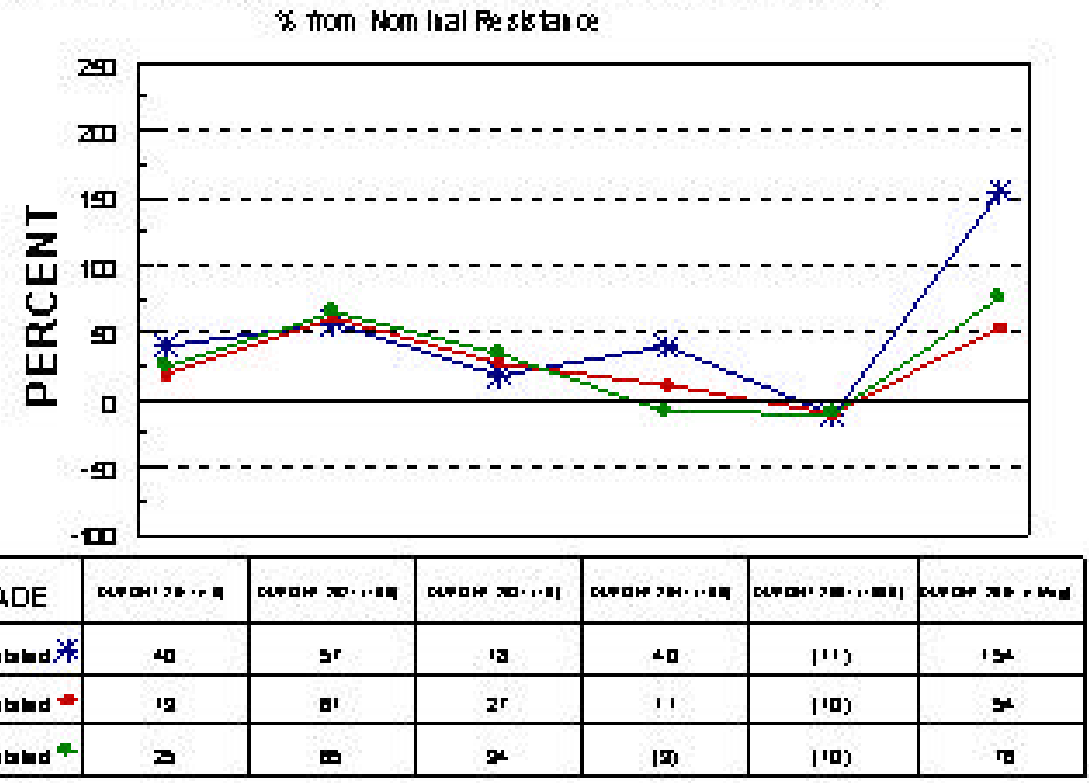

iele h parnifess is romind teel resstora

Dats is sa mil Geore ites

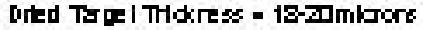

Figure A-1

\section{NORMALIZED SHEET RESISTANCE - DUPONT 2000 SERIES}

Firing Sensitivit y - Printed on Alu mina (Encapsulated)

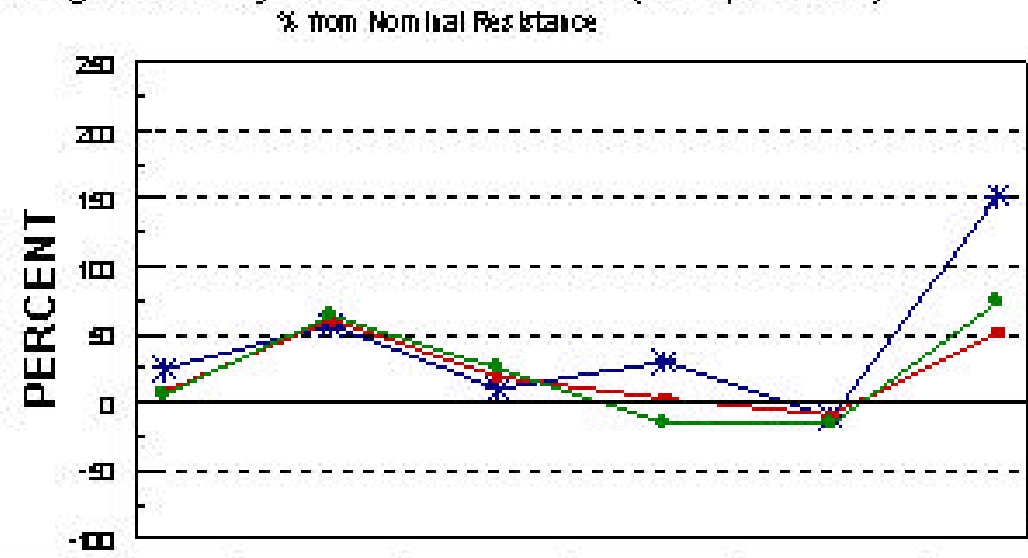

\begin{tabular}{|c|c|c|c|c|c|c|}
\hline RESIS TOR DECADE & $\operatorname{cenan} 3 x \cdot \pi$ & 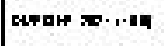 & 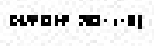 & 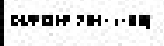 & 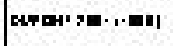 & and an and \\
\hline 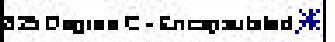 & $\mathbf{z}$ & ar & שי & $\mathbf{m}$ & ניין & 120 \\
\hline 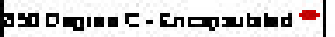 & $\mathbf{a}$ & I & 19 & a & |घ) & 20 \\
\hline I & - & $\mathbf{0}$ & $\mathbf{D}$ & (3) & (18) & $\mathbf{n}$ \\
\hline
\end{tabular}

vilu h parniteds is romind teel retstrax oxt is samiliceore its

Orted Tor

Figure A-2 


\section{UNTRIMMED SHEET RESISTANCE - DUPONT 2000 SERIES}

Composite Print Lot Variability (Encapsulated - 25 mil Geometries)

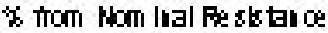

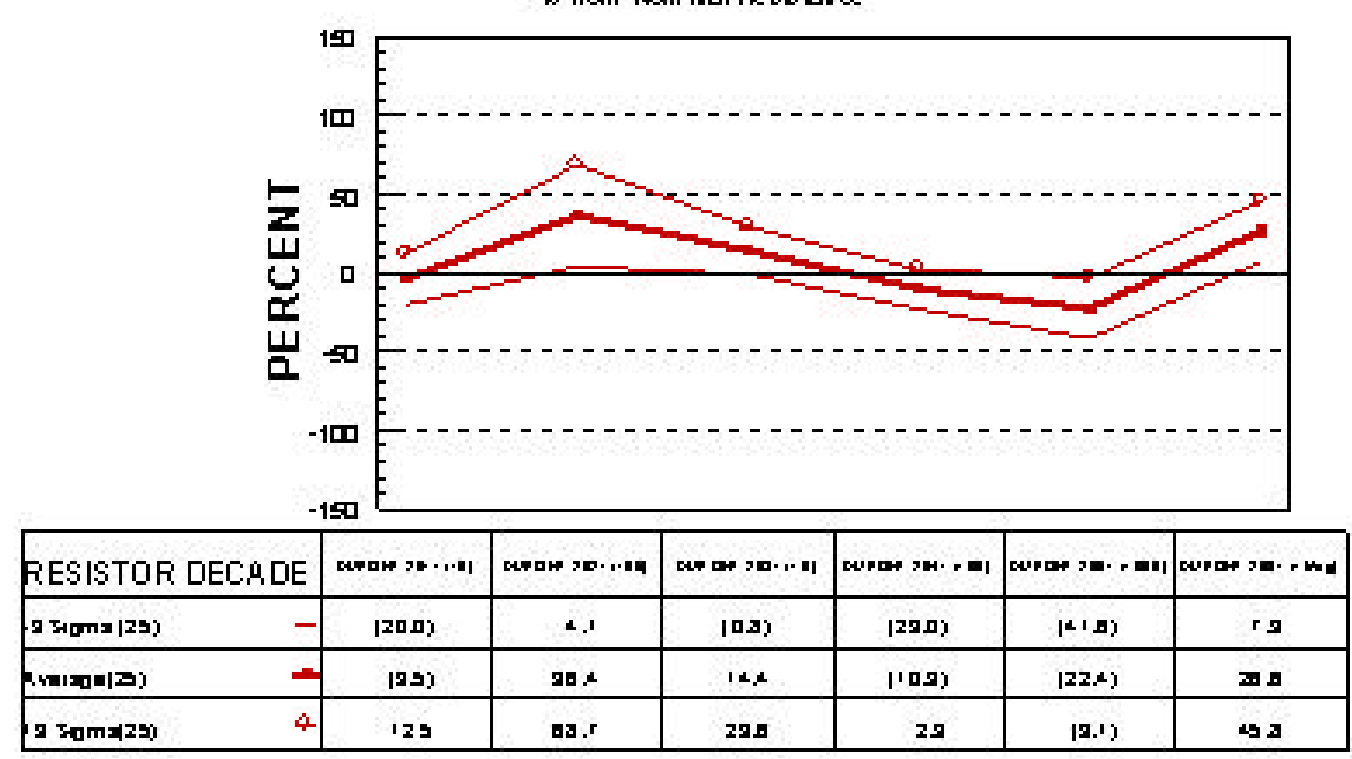

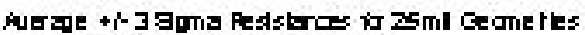

Find alago bedres - TuMruts

Firr Inct化

\section{UNTRIMMED SHEET RESISTANCE - DUPONT 2000 SERIES}

\section{Composite Print Lot Variability (Encapsulated - 50 mil Geometries)}

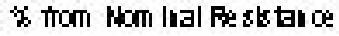

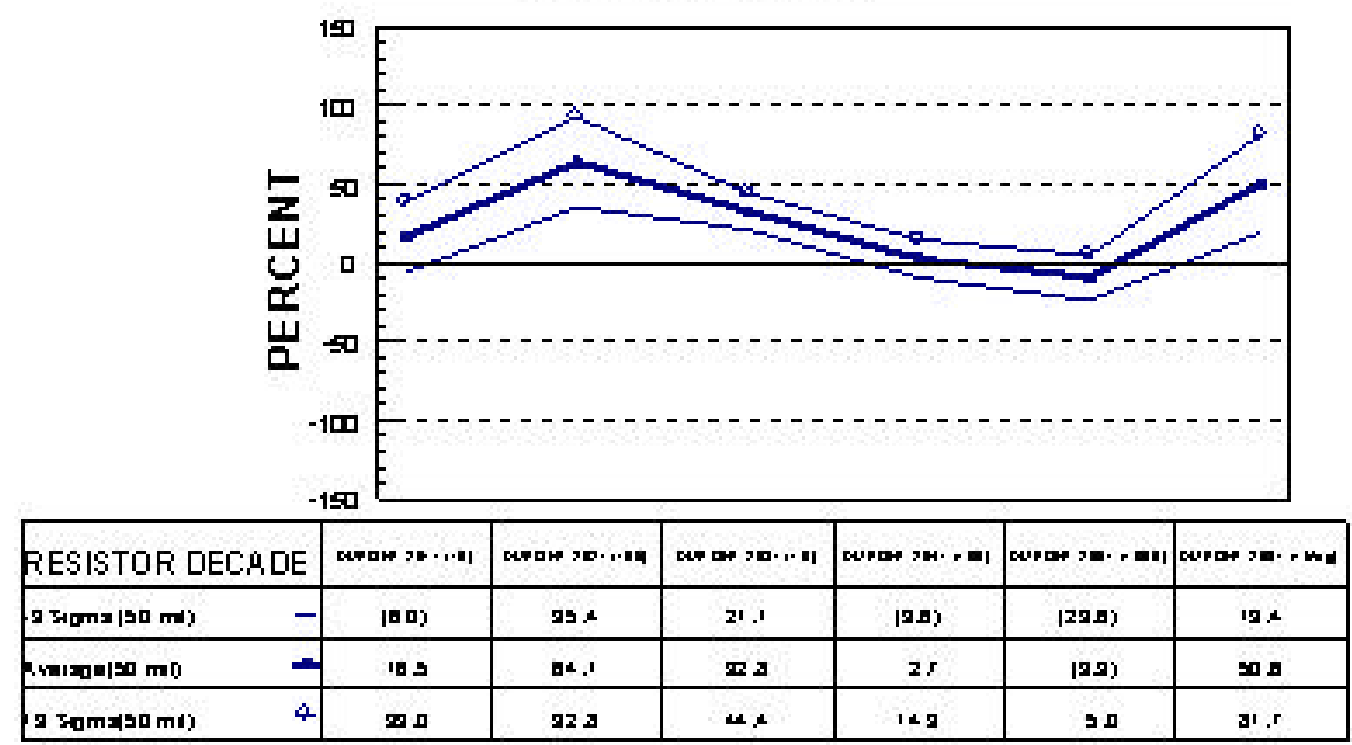

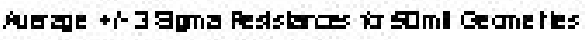

Find alag Dep ars c - TMMruts

Find Inct化

Figure A-4 


\section{UNTRIMMED SHEET RESISTANCE - DUPONT 2000 SERIES}

Composite Print Lot Variability (Encapsulated - 100 mil Geometries)

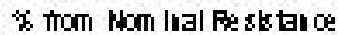

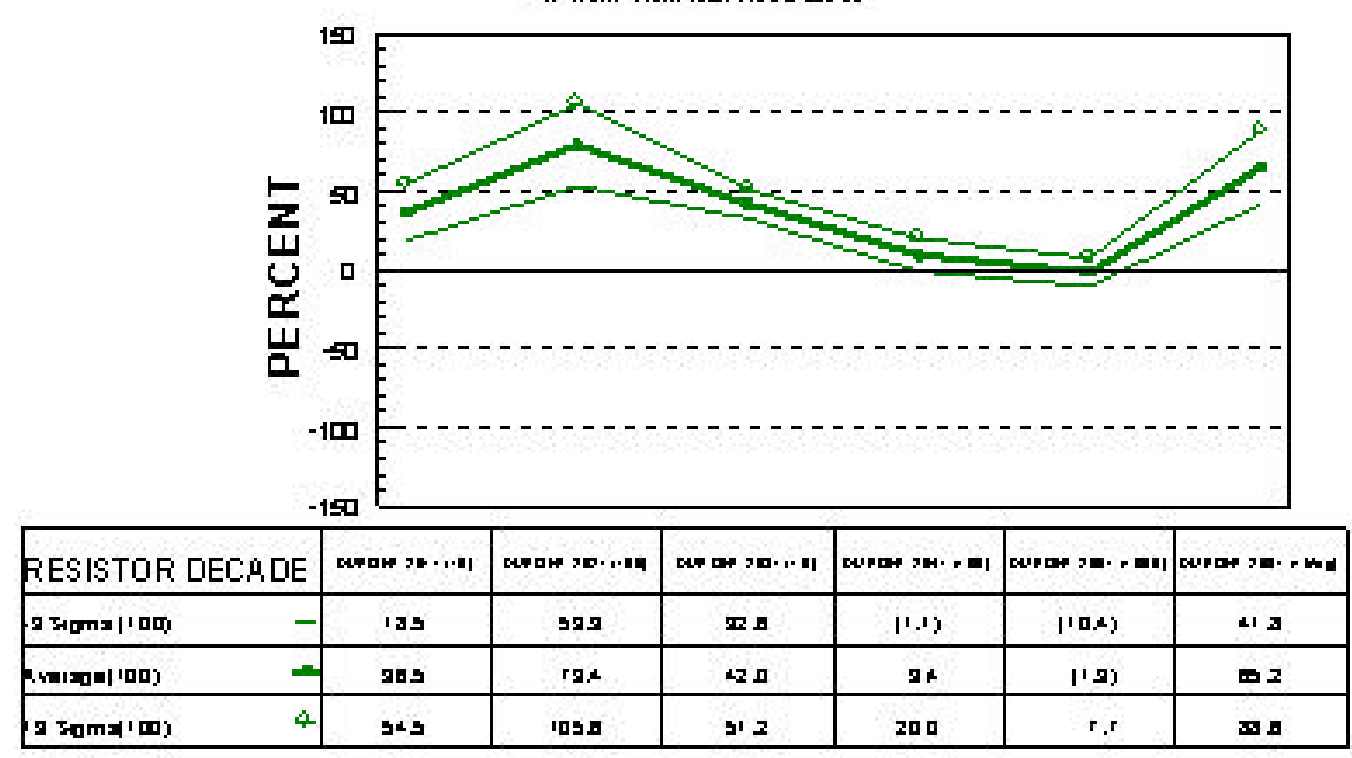

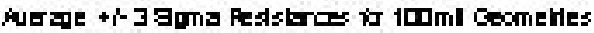

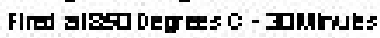

Firre Inct化

\section{UNTRIMMED SHEET RESISTANCE - DUPONT 2000 SERIES}

\section{Composite Print Lot Variability (Encapsulated)}

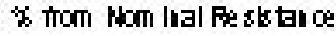

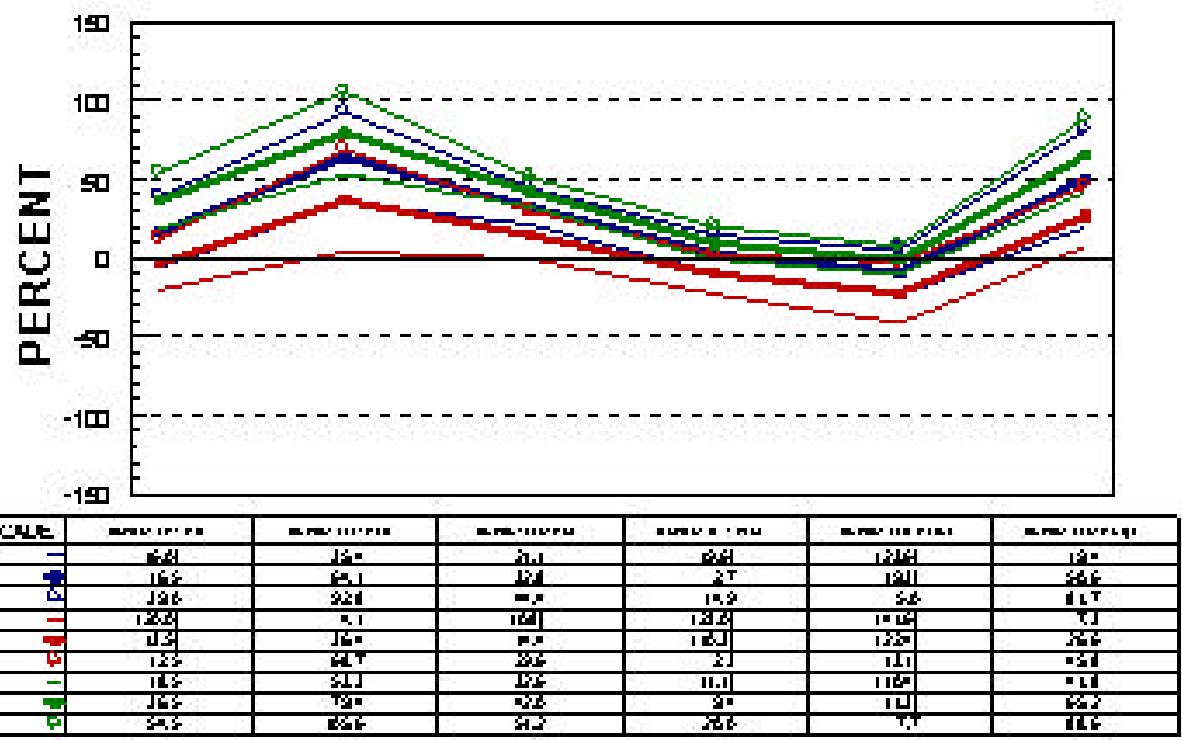

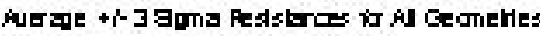

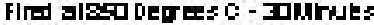

Find Inct化

Figure A-6 


\section{UNTRIMMED SHEET RESISTANCE - DUPONT 2000 SERIES}

Substate Comparison - LTC C vs Alumina

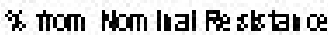

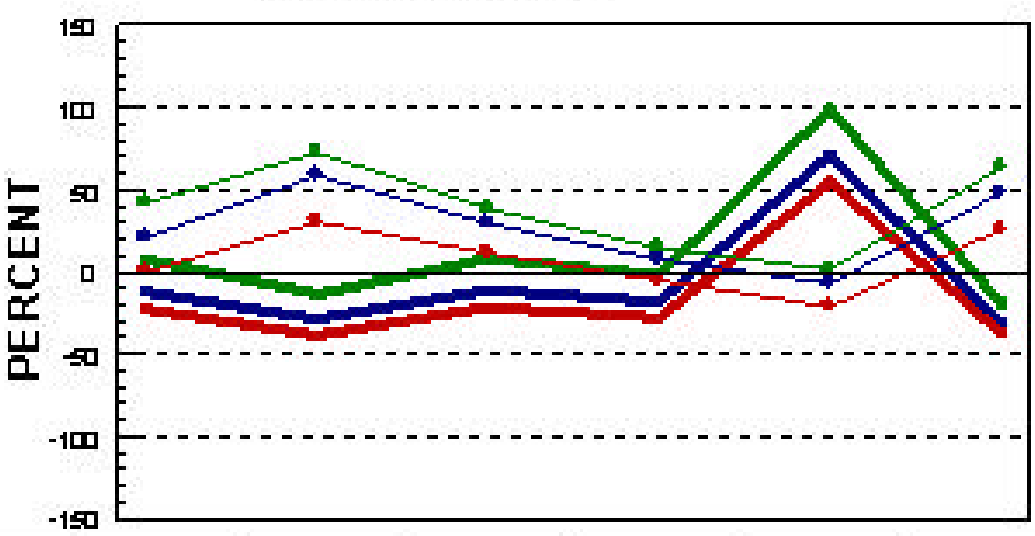

\begin{tabular}{|c|c|c|c|c|c|c|}
\hline RESISTOR DECADE & ומי... & 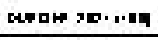 & ום... & 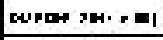 & | In & 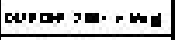 \\
\hline 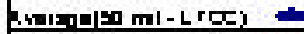 & {$[2.03$} & $\mid 230)$ & 第 & (19 & ris & 翟 \\
\hline (. & |223) & 进 $n$ & $\mid 21,0)$ & $12 r, r)$ & 325 & ars 3 \\
\hline (n) & $r_{3}$ & 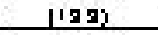 & a.1 & (1'B) & 23 & 1] \\
\hline 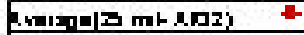 & a) & mo & $11, r$ & 13.13 & 210 & as \\
\hline AnI & 210 & s. & 포 & $\mathrm{rg}$ & $(\mathbf{r g})$ & 40 \\
\hline 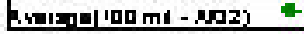 & 220 & $2 \mathrm{z}$ & 国 & $14, r$ & 13 & 四 \\
\hline
\end{tabular}

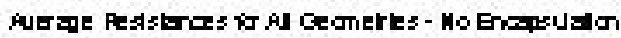

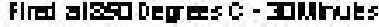

Figure A-7

\section{ENCAPSULATION SENSITIVTY - DUPONT 2000 SERIES \\ Resistors Printed on Alumina - 25 mil Geometries \\ x tom Nomilal Restrtice}

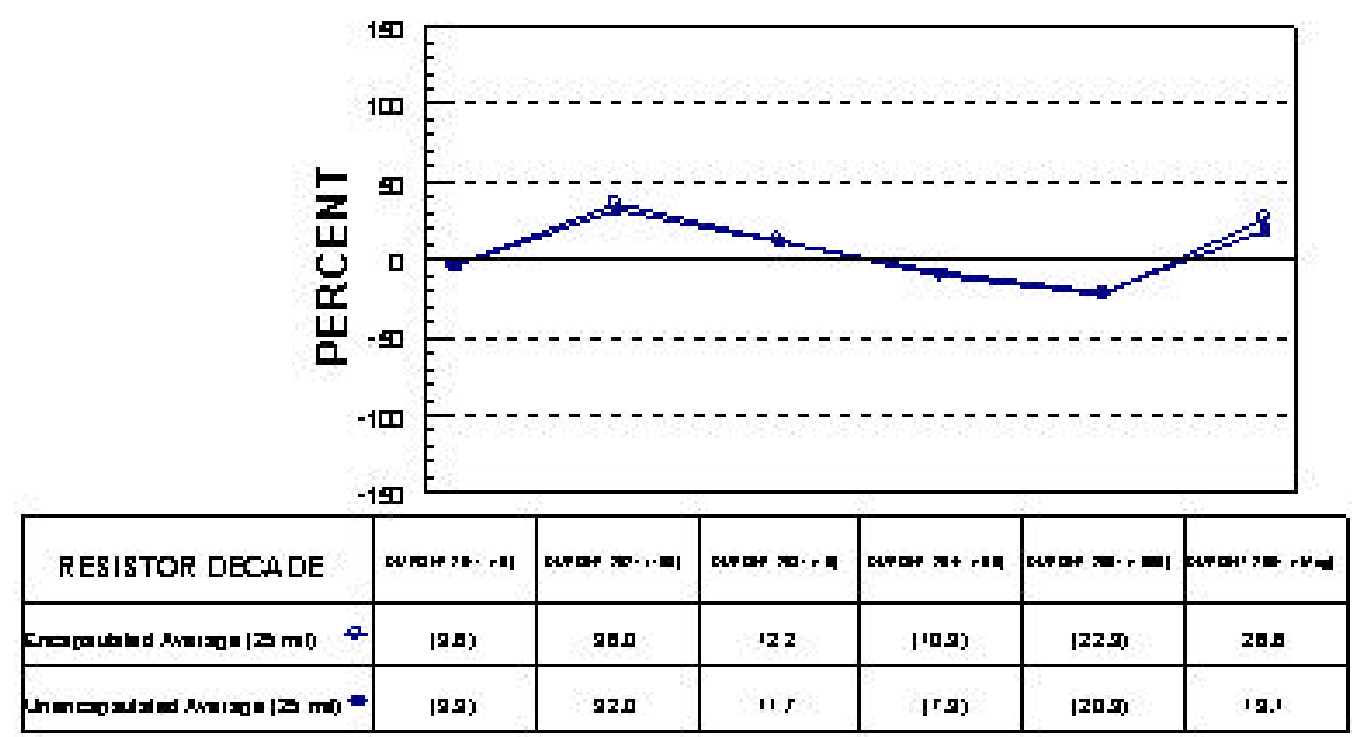

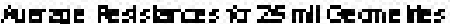

Find alaxg 0edresc - Touruts

Empes ted in cesties

Figure A-8 


\section{ENCAPSULATION SENSITIVITY - DUPONT 2000 SERIES \\ Resistors Printed on Alumina - $\mathbf{5 0}$ mil Geometries \\ x tom Nomilal Res stance}

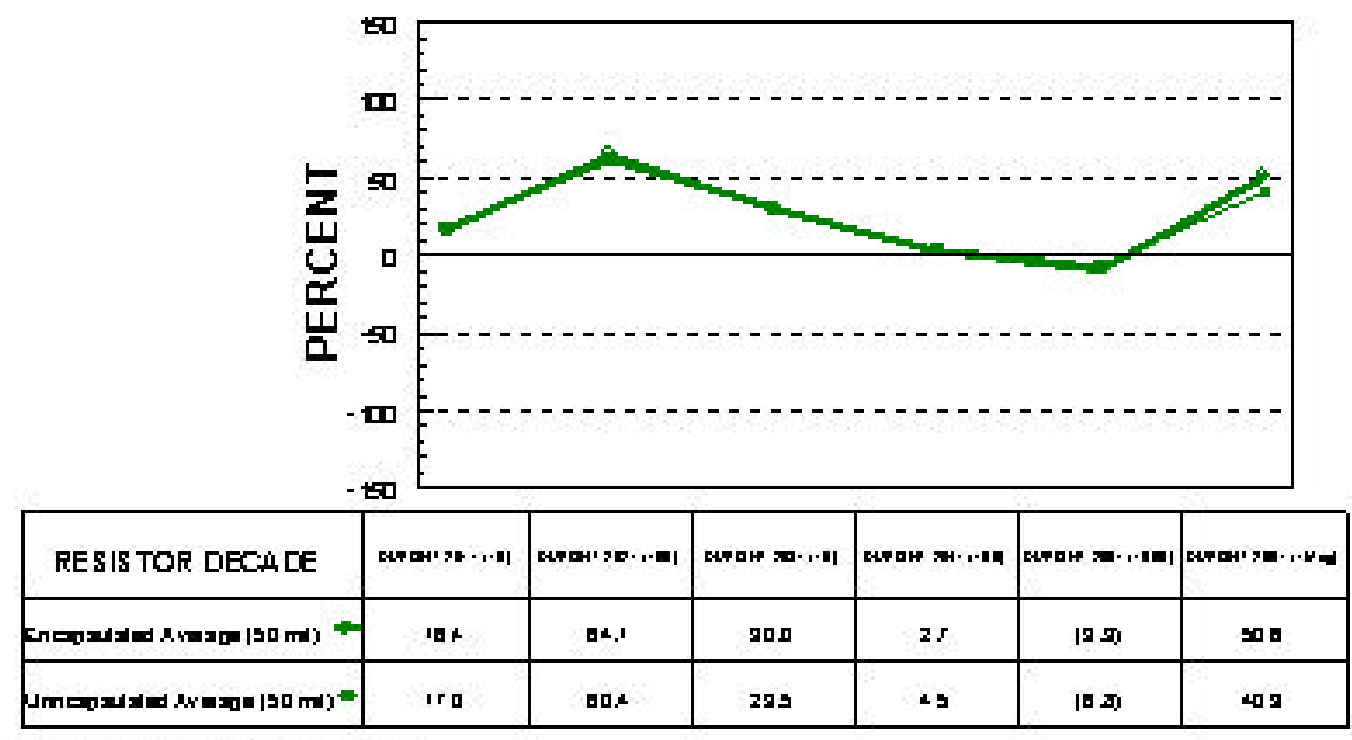

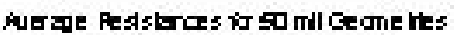

Find alaso oed ars c - IMuruts

Emples ted In CEA 16r

Figure A-9

\section{ENCAPSULATION SENSITIVTY - DUPONT 2000 SERIES}

\section{Resistors Printed on Alumina - 100 mil Geometries}

s tom Nomilıal Reststice

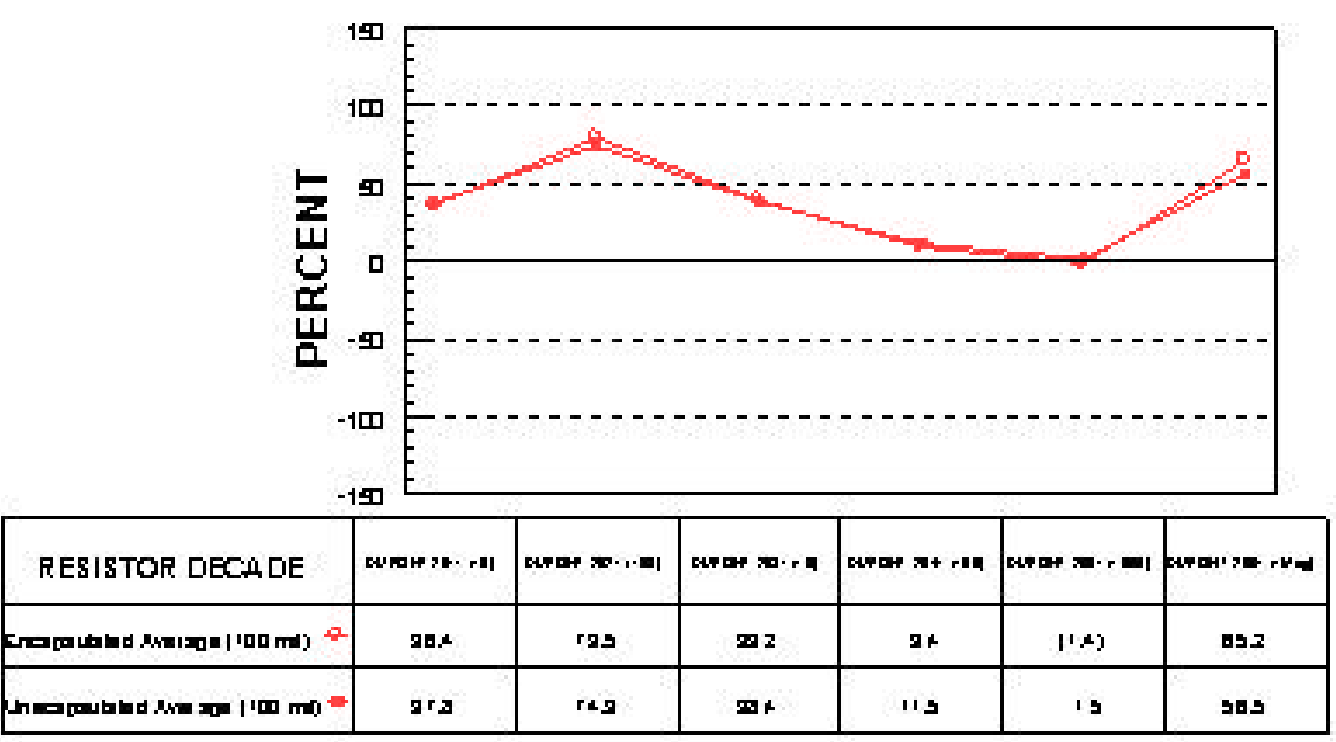

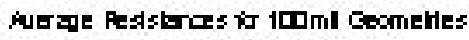

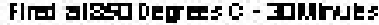

Emples ted in CEA 16

Figure A-10 


\section{RESISTOR GEOMETRY \& ORIENTATION AFFECTS}

\section{DuPont 2000 Series Printed on Alumina}

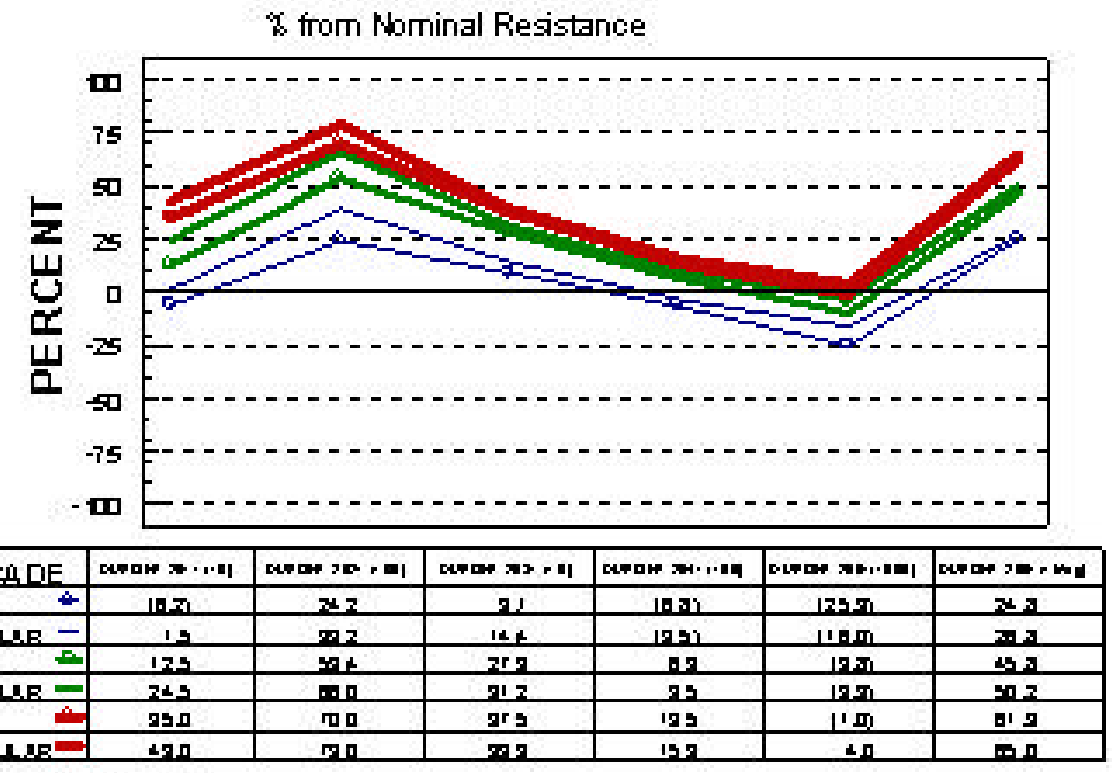

smpes were flred alagdeg. C \& Uralxer Orierblon Ret b bestsa Ler h Wireda OHerbbonls Reble beqeege Trad

\section{RESISTOR GEOMETRY \& ORIENTATION AFFECTS}

\section{DuPont 2000 Series Printed on Alumina - 25 mil Geometries}

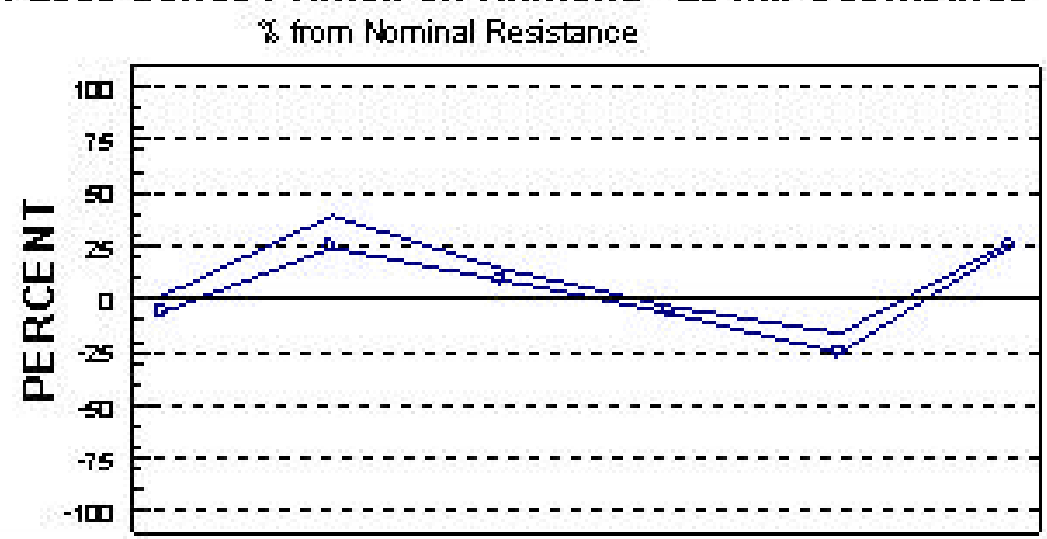

\begin{tabular}{|c|c|c|c|c|c|c|}
\hline RESISTOR DECALDE & $\sin a x+\cdots$ & 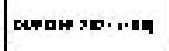 & 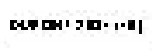 & ound & 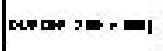 & 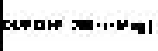 \\
\hline$\triangle$ MIL PARALLEL & 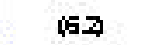 & $24 z$ & S.1 & 658 & 63 & $2+8$ \\
\hline 5 MIL P EREA O KU LAR - & 15 & 포 & 14.4 & 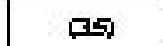 & (150) & 西 8 \\
\hline
\end{tabular}

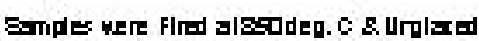
Orierbion Rets b Restsi Ler h Wireda orterbbonls Reble bepregre Trad 


\section{RESISTOR GEOMETRY \& ORIENTATION AFFECTS}

\section{DuPont 2000 Series Printed on Alumina - $\mathbf{5 0}$ mil Geometries}

* from Nominal Resistance

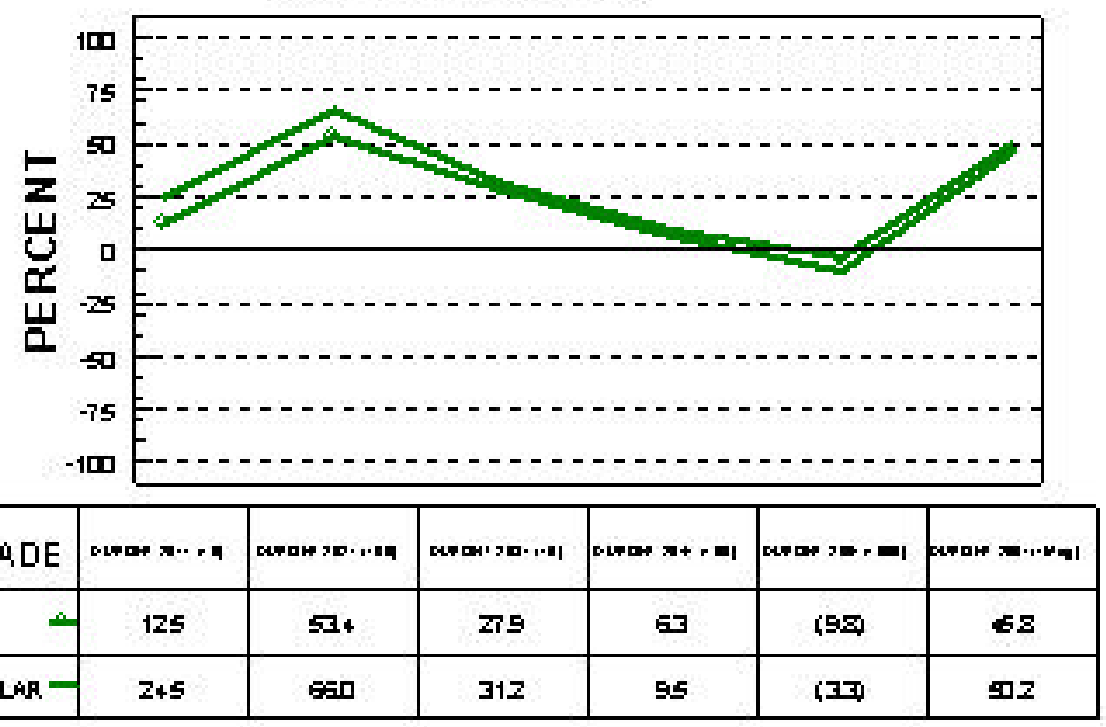

Emples were Flred alagded.c \& Urilar

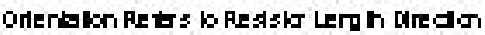
Orierblonis Reble bepregee Trad

\section{RESISTOR GEOMETRY \& ORIENTATION AFFECTS}

\section{DuPont 2000 Series Printed on Alumina - $\mathbf{1 0 0}$ mil Geometries}

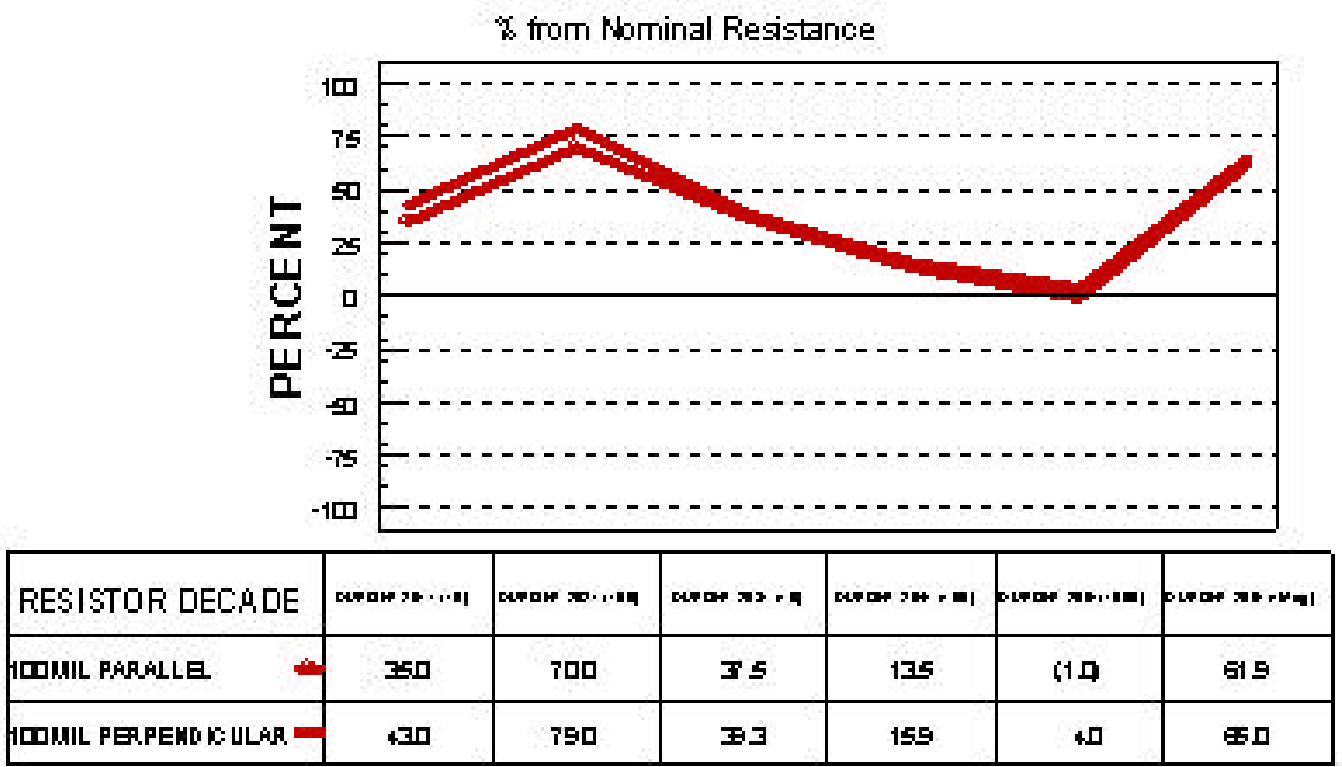

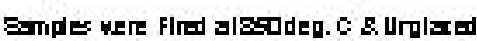

Onterblon Retes b Ressig Lerd Wireda

orterbibnis Reble beperege Trad

Figure A-14 


\section{RESISTOR GEOMETRY \& ORIENTATION AFFECTS}

\section{DuPont 2000 Series Printed on Alumina}

$\approx$ fom Target Dried Thickness

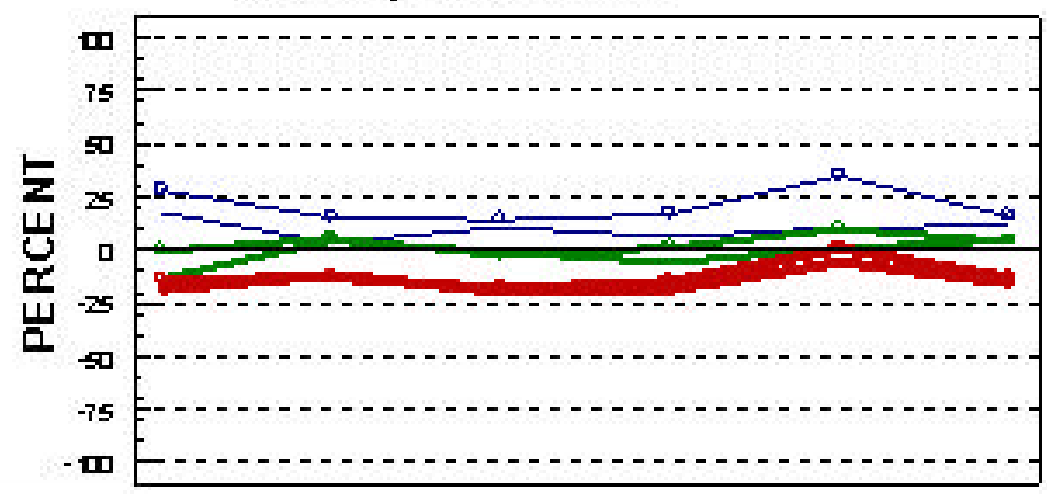

\begin{tabular}{|c|c|c|c|c|c|c|}
\hline RESISTOR DECAD DE & 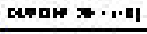 & and & netan & 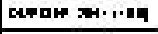 & 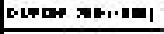 & 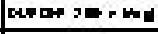 \\
\hline 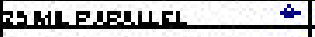 & 259 & 122 & 142 & $1 \mathrm{r}, \mathrm{I}$ & 220 & 128 \\
\hline 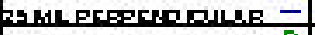 & irg & n.r. & 110 & .2. & $10 x$ & 11. \\
\hline 20MLENESHCL & $10=2$ & 3.5 & 1281 & 19 & 100 & 42 \\
\hline 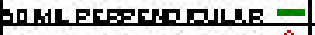 & لماصل & 4 & 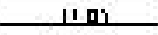 & $1 \mathrm{as}$. & 10 & $\alpha, r$ \\
\hline IOU MLPNRMLEI A & 14 제 & $128)$ & (1י 2 & $\mid \alpha, n$ & a.r & 篮 \\
\hline 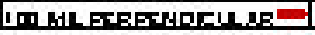 & الغهل & 11102 & 14ar & 113010 & 12.31 & 119. \\
\hline
\end{tabular}

Torgel dited Horess is 19miarere

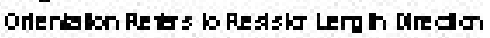

Orierblonis Reble bepregee Trad

\section{RESISTOR GEOMETRY \& ORIENTATION AFFECTS}

\section{DuPont 2000 Series Printed on Alumina - 25 mil Geometries}

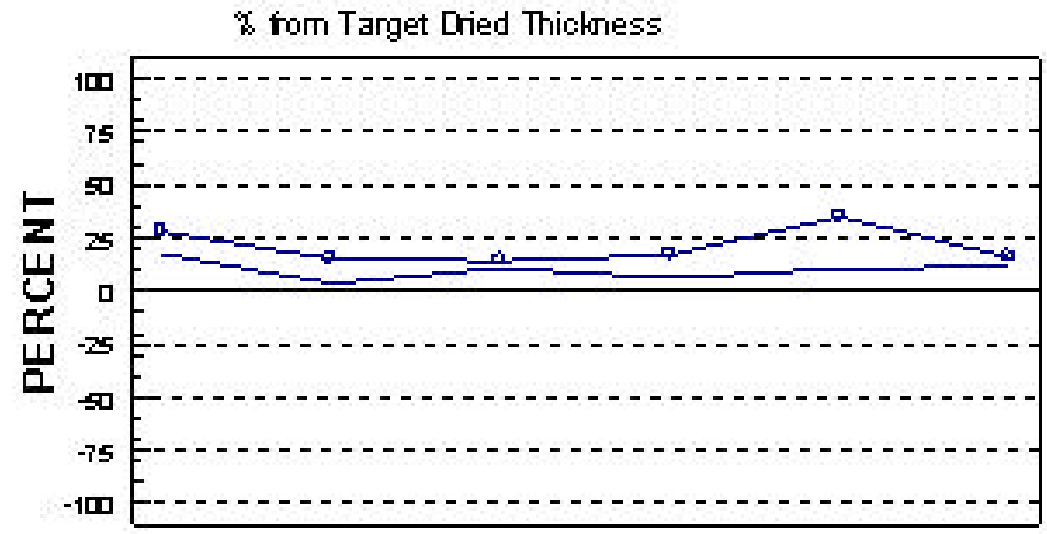

\begin{tabular}{|c|c|c|c|c|c|c|}
\hline RESISTOR DECADDE & owan $x \cdots+4$ & 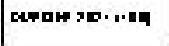 & | & butan $x+r|r|$ & 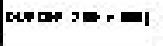 & | \\
\hline EMIL PAPULLLEL & 279 & $15 z$ & $14 z$ & 17.1 & 五 & 68 \\
\hline Б MIL P ERPEONULAR - & 176 & 37 & 110 & 63 & $\mathrm{Q} 8$ & 11.5 \\
\hline
\end{tabular}

Tagel dited Noress is 19milaore

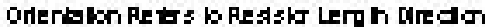

Orterblonis Reble bepreege Trabd

Figure A-16 


\section{RESISTOR GEOMETRY \& ORIENTATION AFFECTS}

\section{DuPont 2000 Series Printed on Alumina - 50 mil Geometries}

* fom Target Dried Thickness

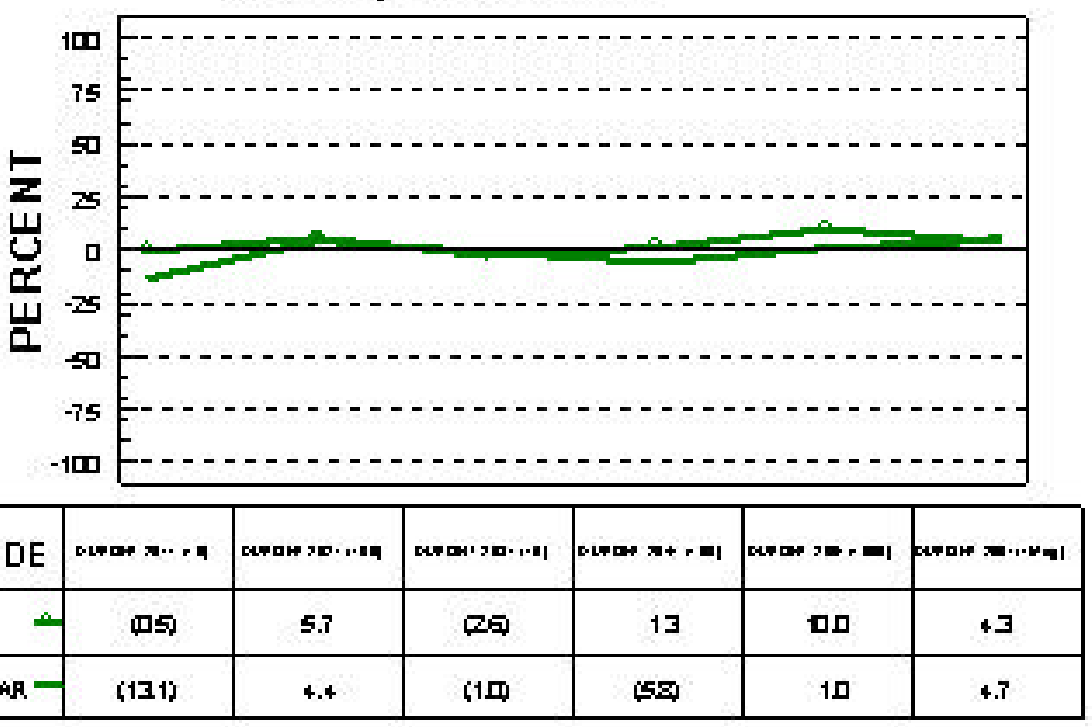

Tamel dited Horess is 19miacore

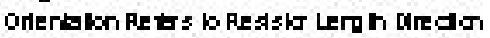

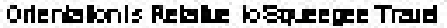

\section{RESISTOR GEOMETRY \& ORIENTATION AFFECTS}

\section{DuPont 2000 Series Printed on Alumina - 100 mil Geometries}

* fom Target Dried Thickness

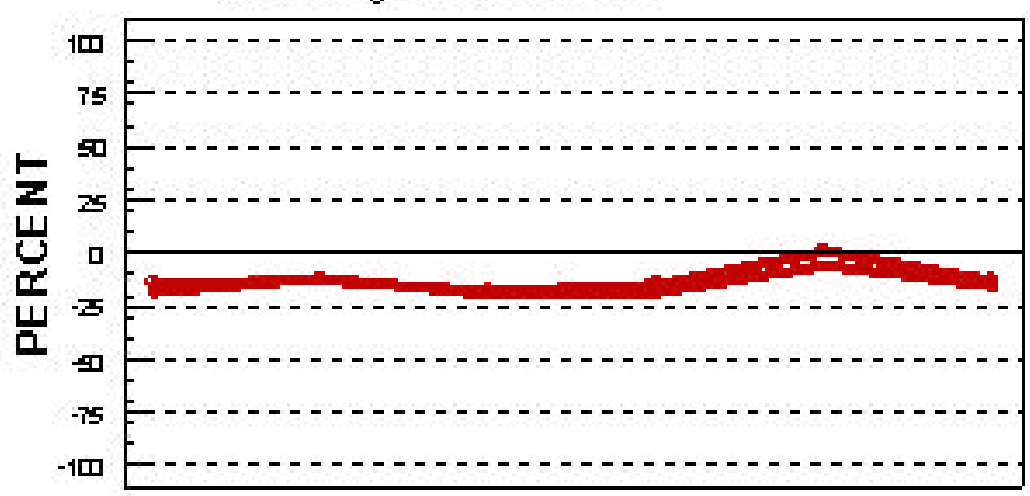

\begin{tabular}{|c|c|c|c|c|c|c|}
\hline RESISTOR DECADE & 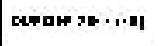 & 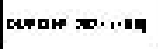 & $\cos x+\pi$ & 1 & 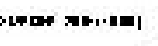 & 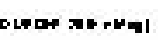 \\
\hline IسMIL PAPALLE & (147) & (12ब & $6 \pi 9$ & $(14.7)$ & $\mathrm{ar}$ & (स्) \\
\hline IDMIL PERPENO $\mathrm{C}$ ULAR & $(184)$ & (11日) & (⿻) & (124) & 59 & 63 \\
\hline
\end{tabular}

Tagel dited Noress is 19milaore

Orierbion Rets b Restsk Ler h Wredd

orterbbonls Reble bepregre Trad

Figure A-18 


\section{THICKNESS RELATIONSHIP - DUPONT 2000 SERIES}

\section{Wet, Dried \& Fired Thicknesses}

Printed on Alumina

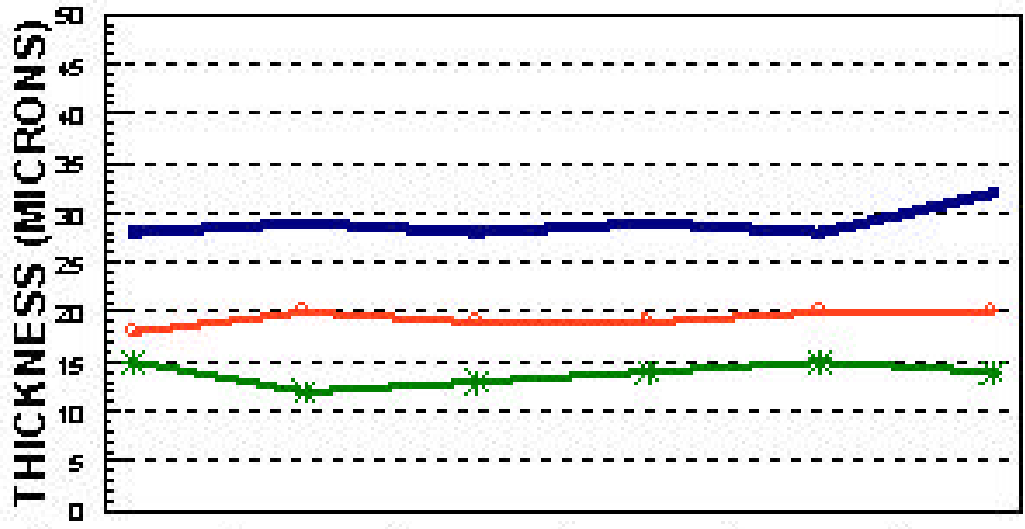

\begin{tabular}{|c|c|c|c|c|c|c|}
\hline RE SIST OR DECÁDE & 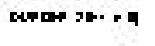 & cupare so.,.19 & curae vern & | & | & | \\
\hline MET TH NKMEES & $z$ & 조 & 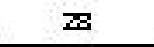 & 조 & $\boldsymbol{B}$ & Iz \\
\hline DRIED THCKES & 18 & ד & 19 & 19 & ד] & ד \\
\hline F IRED TH CKNEE & 15 & 12 & 13 & 14 & ts & 14 \\
\hline
\end{tabular}

Drted Tro

Figure A-19

APPENDIX B

COMPARATIVE DATA FOR UNTRIMMED DU PONT 1400/2000 SERIES RESISTORS PRINTED

ON ALUMINA 
UHTRIMWED SHEE T RESISTANCE COMPARISON - PRODUCTION WATERIALS DuFont 1400/2000 Serie I Be Ilitor Componl tonI

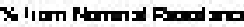

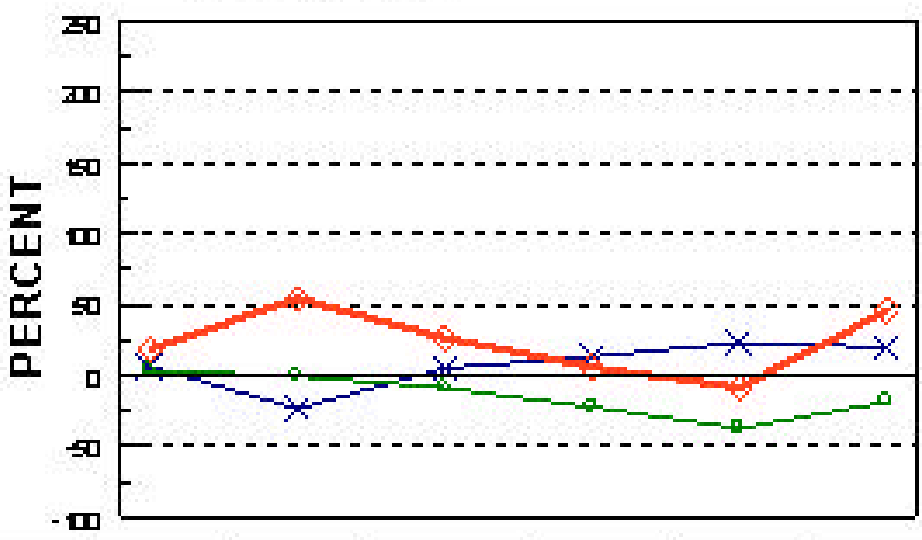

\begin{tabular}{|c|c|c|c|c|c|c|}
\hline RESISTOR DECADE & $100 \mathrm{HA}$ & шони & $1 \mathrm{Ko} \mathrm{HM}$ & 10кони & 1⿴囗十оном & 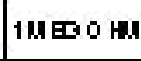 \\
\hline 1400 Series (Alumina) & 6.0 & $(23,3)$ & 50 & 13.0 & 23.2 & 200 \\
\hline 2000 Series (Alumina) & 18.7 & 54.3 & 26.6 & 5.8 & (8.6) & 45.7 \\
\hline 2000 Series (LTCC) & 3.7 & $(0.6)$ & (8.8) & $(22.2)$ & $(37.6)$ & $(18.6)$ \\
\hline
\end{tabular}

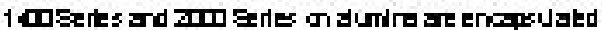

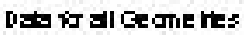

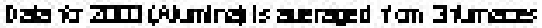

Figure B-1

\section{UNTRIMMED SHEET RESISTANCE COMPARISON - FURNACES}

DuP ont 1400 Series Resist or Compositions

क tom Moming R.eststrax

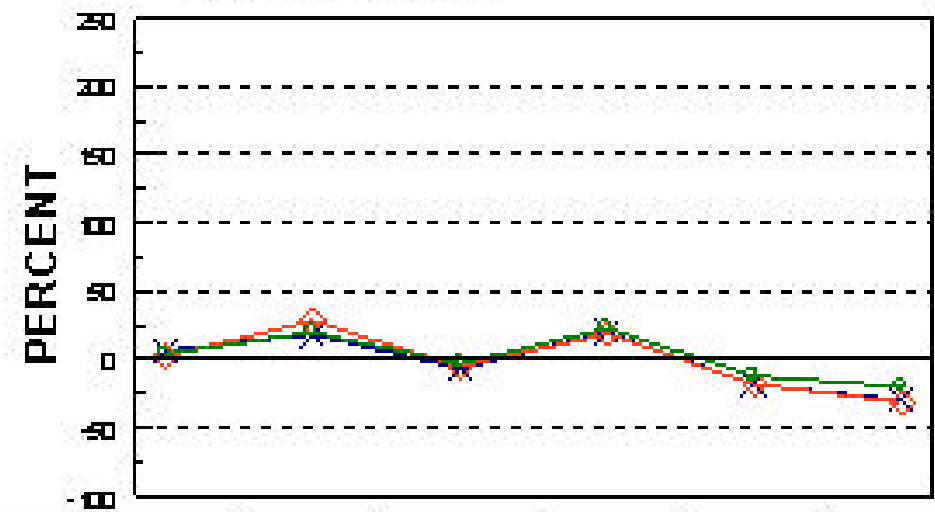

\begin{tabular}{|c|c|c|c|c|c|c|}
\hline RESISTOR DECADE & $100 \mathrm{HM}$ & шонм & $1 \mathrm{KO} \mathrm{HM}$ & 10 10 нМ & 1⿴кони & $1 M E 0 \mathrm{HM}$ \\
\hline 1400 Series - CEA4164 & 6.7 & 18.5 & $(6.4)$ & 19.8 & $(18.2)$ & $(29.6)$ \\
\hline 1400 Series - CE94165 & 2.4 & 283 & (5.0) & 18.8 & $(17.8)$ & 131.4 \\
\hline 1400 Series - CE94168 & 42 & 19.9 & $(2.8)$ & 22.8 & $(11.7)$ & $(19.8)$ \\
\hline
\end{tabular}

1 Cosertes ondumina are ercopsuatd

ots is s0 mil Georre its

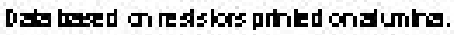

Figure B-2 
UNTRIMMED SHEET RESISTANCE COMPARISON - FURNACES

DuPant 2000 Series Resistor Compositions

s tom Momind R.ets tona

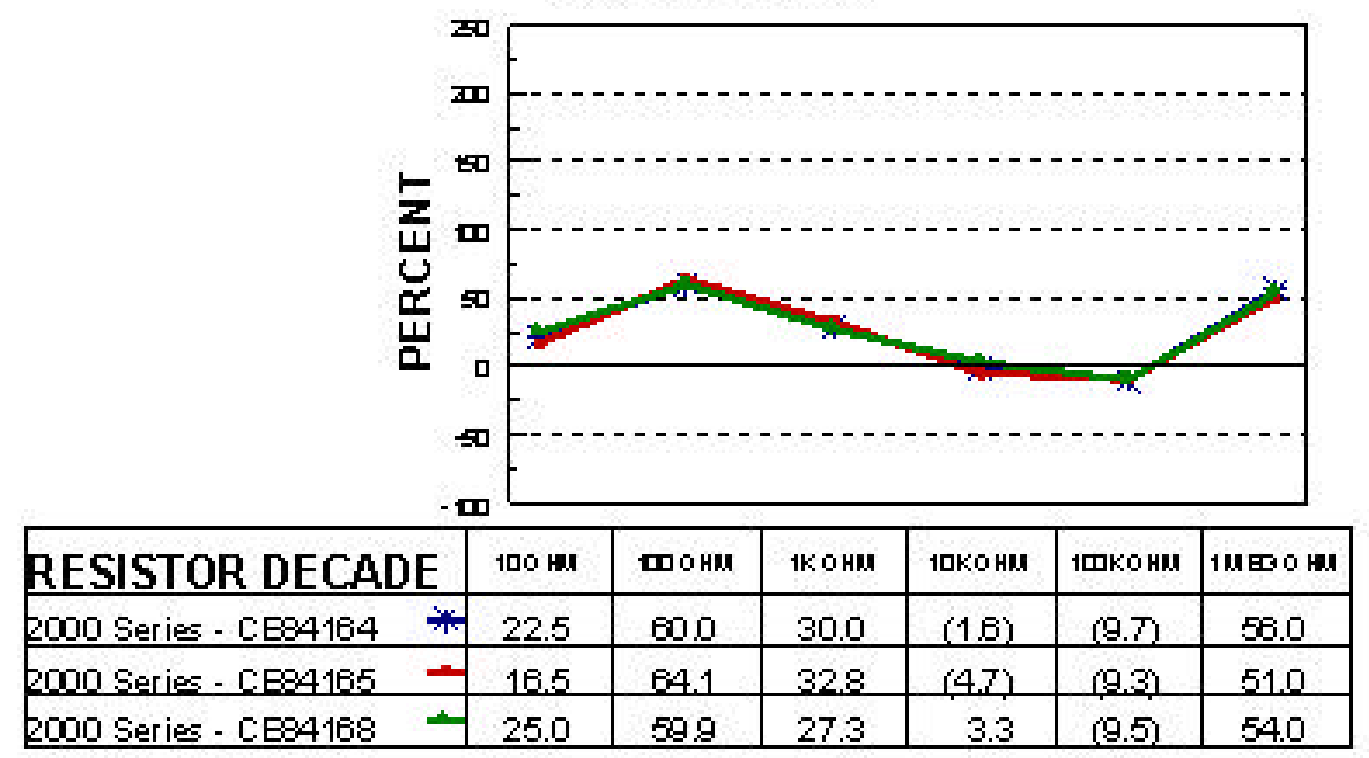

allestes ondumina are eropsustd

oxt is sa mil Geore ites

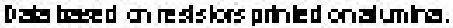

Figure B-3

\section{UNTRIMHED SHEET RESIST ANCE COMPARISON - FURNACE CE 84164}

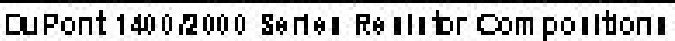

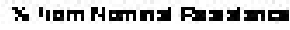

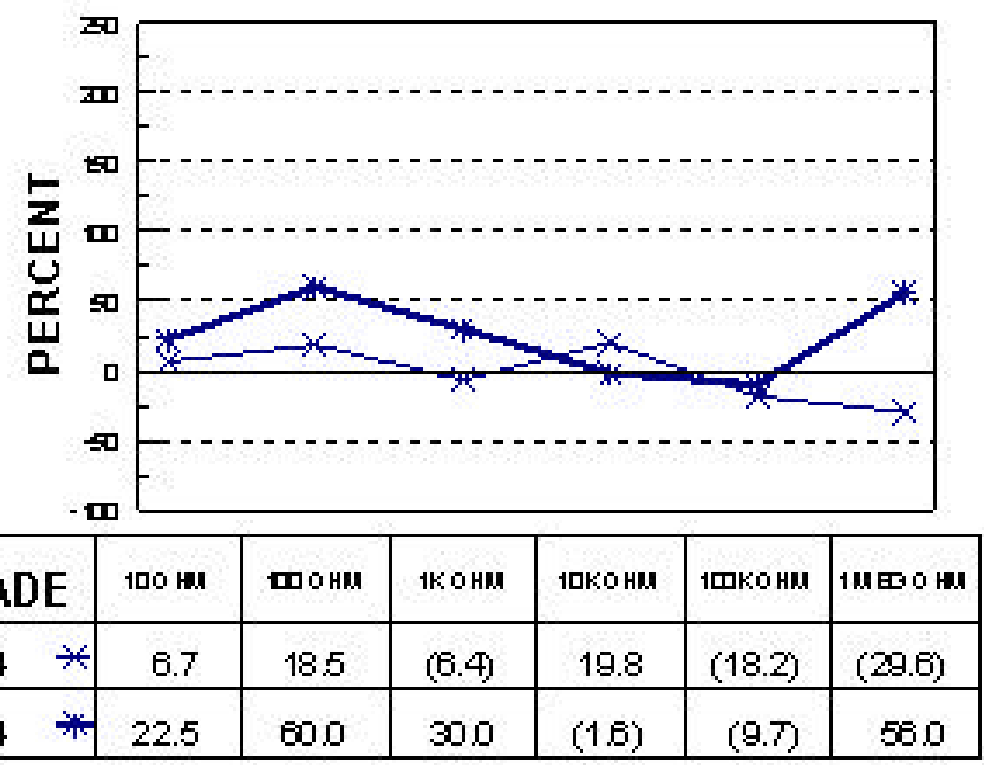

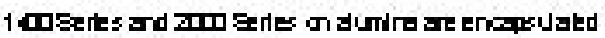

ots is sum meorre thes

ots tored an restskrs phited onaluming.

Figure B-4 
UNTRIMHED SHEET RESISTANCE COMPARISON - FURNACE CE 84165

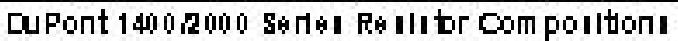

X iam Mamnal Famsilmo

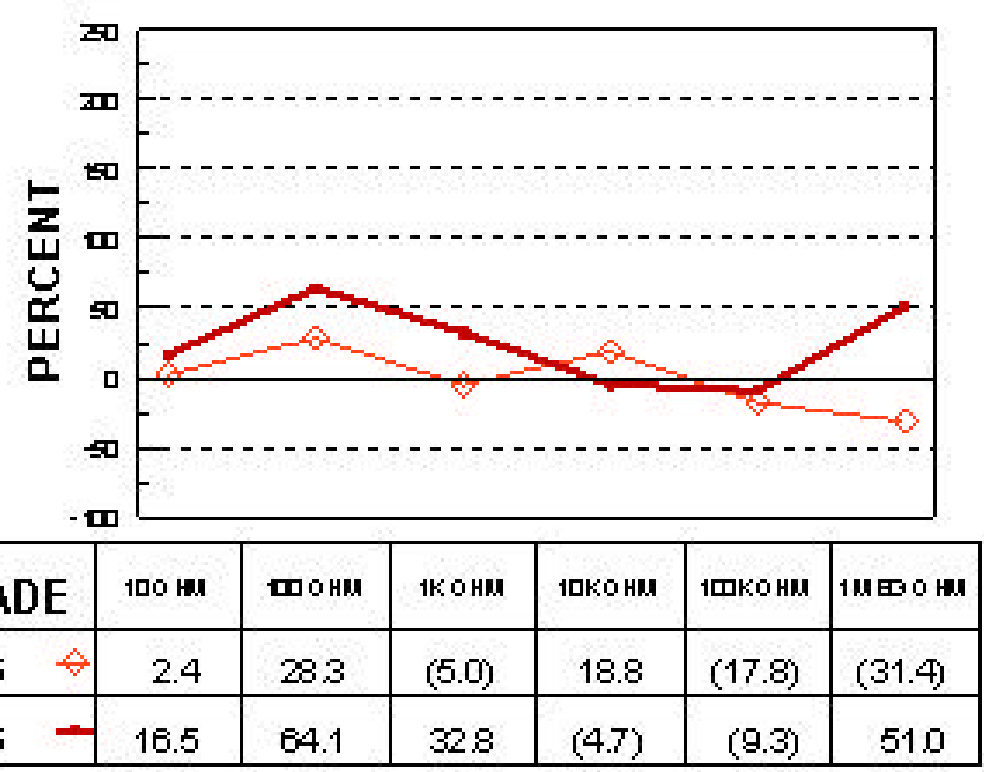

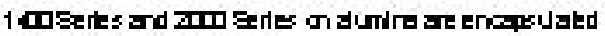
Dats is sa mil Geore ites

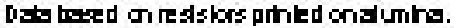

\section{UNTRIMHAED SHEET RESIST ANCE COMPARISON - FURNACE CE84168}

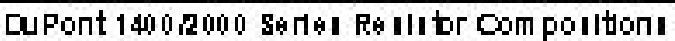

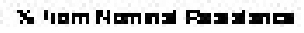

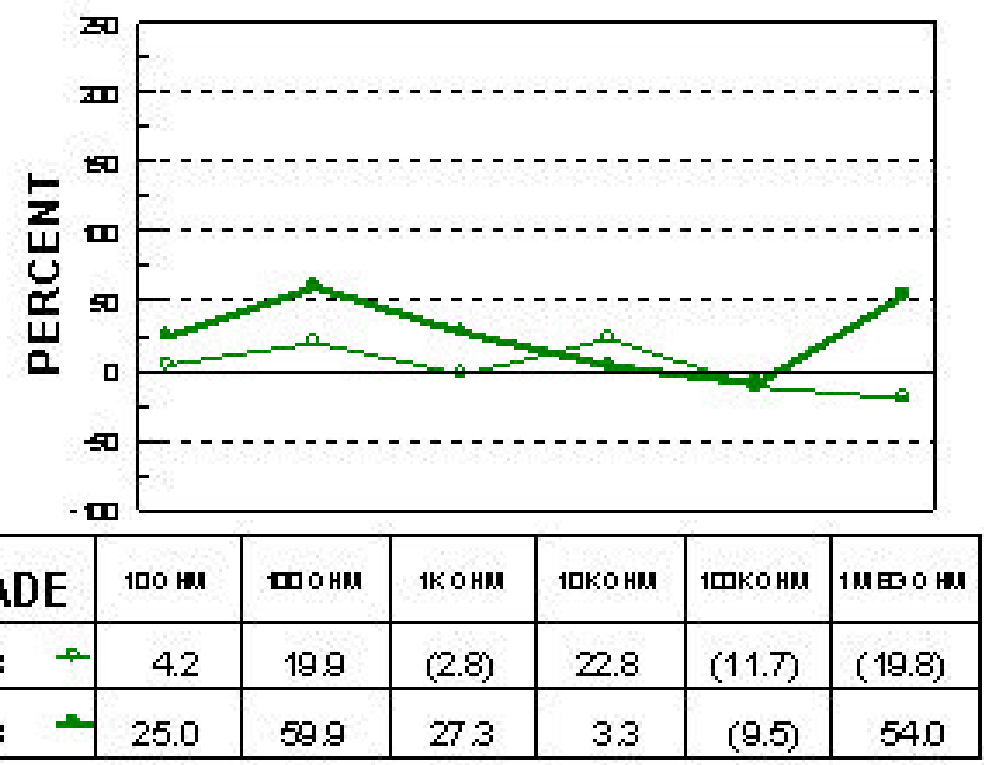

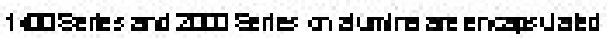

ots is sum meorre thes

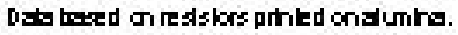

Figure B-6 
APPENDIX C

DU PONT 2011 RESISTOR PRINTING DATA

(10 Ohm)

\section{FIRING PROFILE SENSITIVTY DUPONT 2011(10 OHMS PER SQUARE)}

Actual Values - Printed on Alumina

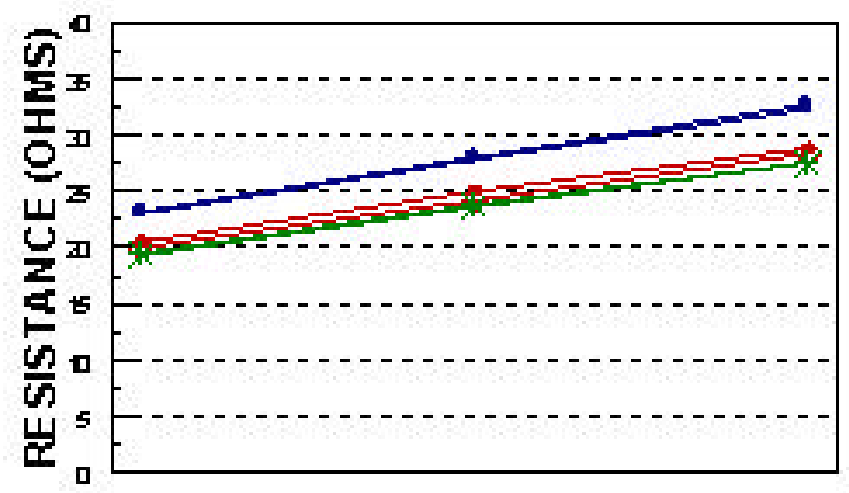

\begin{tabular}{|c|c|c|c|}
\hline RES IS TOR GEOMETRY & $\boldsymbol{m}$ & $=n$ & $\cdot=m i$ \\
\hline 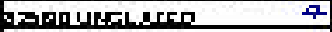 & 200 & 253 & 929 \\
\hline gapogherg & 292 & 2301 & $92, r$ \\
\hline 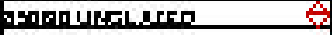 & 200 & 242 & 2302 \\
\hline 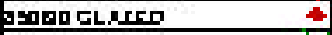 & 205 & 230 & 230 \\
\hline 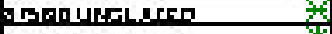 & 192 & 29. & ב ב \\
\hline Spongleren & 192 & 201 & $2 \mathrm{rg}$ \\
\hline
\end{tabular}

Momind avired reststanc is Dotorms.

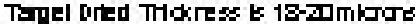

Emples fredincE $E$ 1 19

Figure C-1 


\section{FIRING PROFILE SENSITIVITY}

DUPONT 2011(10 OHMS PER SQUARE)

Percent fr om Nominal Values - P rinted on Alumina

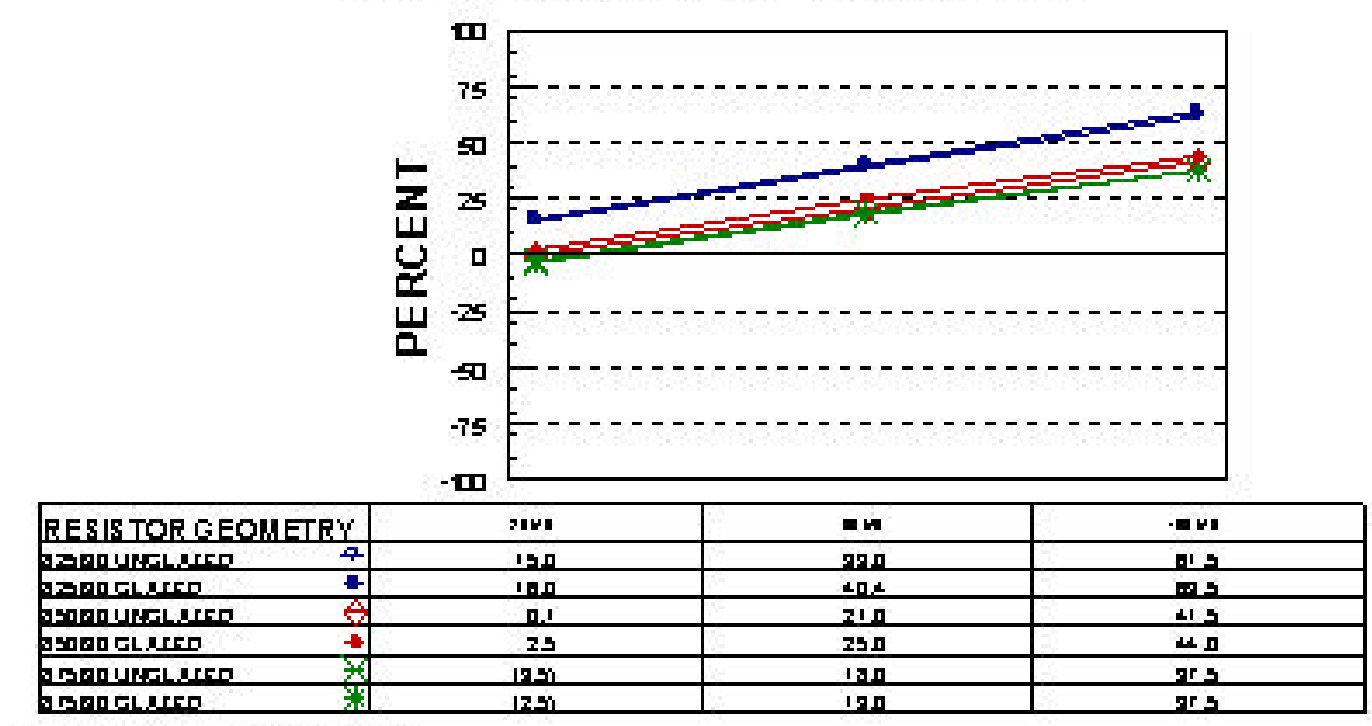

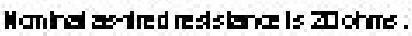

Tarpel brted THdkress b 18-70milars

Emples fred Inc Eat 1 (

Figure C-2

FURNACE SENSITIMTY

DUPONT 2011(10 OHMS PER SQUARE)

Actual Values - Printed on Alumina

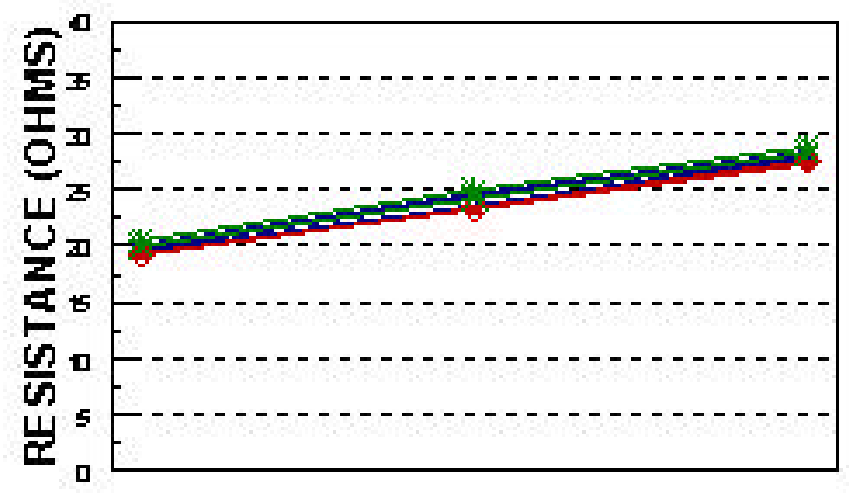

\begin{tabular}{|c|c|c|c|}
\hline RES ISTOR GEOMETRY & $\boldsymbol{x} \mathbf{n}$ & $=\mathbf{m}$ & . mul \\
\hline 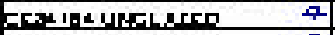 & 192 & 79. & $2 r a$ \\
\hline 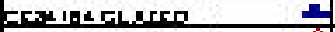 & 192 & 242 & 232 \\
\hline 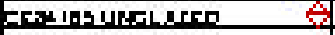 & 192 & 274 & $2 r 8$ \\
\hline 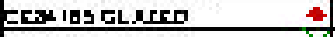 & 192 & 293 & $2 \mathrm{rg}$ \\
\hline 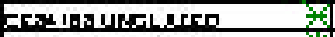 & 200 & 242 & 232 \\
\hline 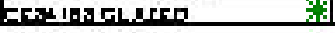 & בחב & $28 \pi$ & 231 \\
\hline
\end{tabular}

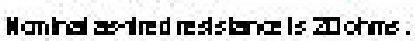

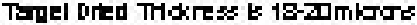

semples fied wi hagraprote

Figure C-3 


\section{FURNACE SENSITIVITY}

\section{DUPONT 2011(10 OHMS PER SQUARE)}

Percent fr om Nominal Values - P rinted on Alumina

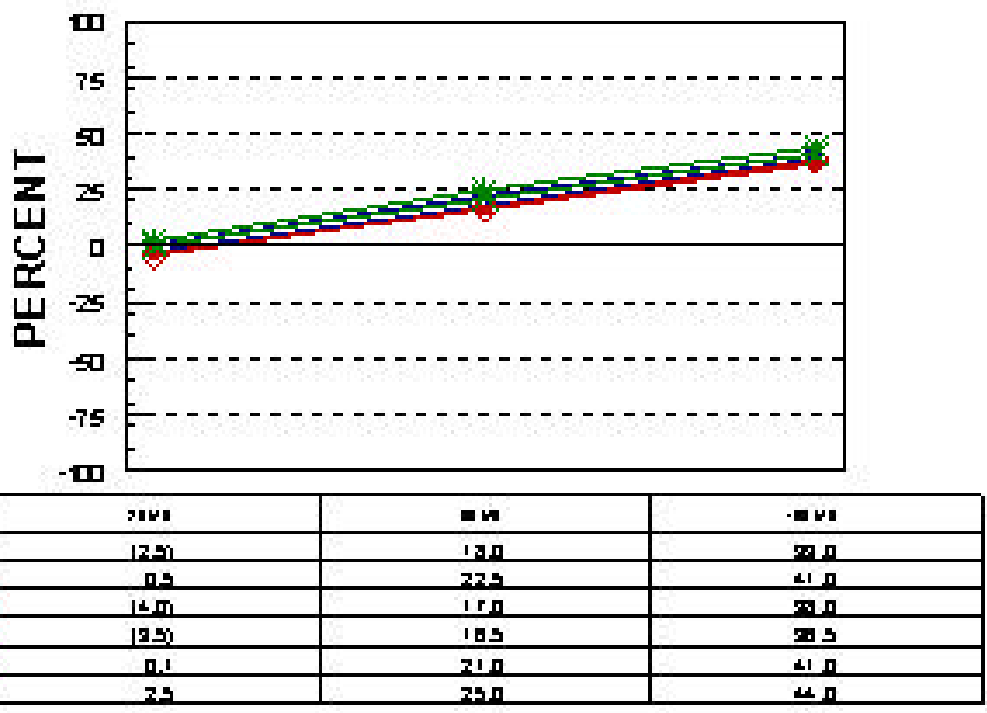

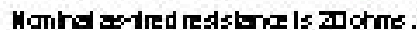

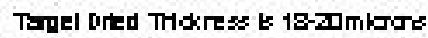

Emples fird withagroprote

\section{NORMALIZED SHEET RESISTANCE DUPONT 2011(10 OHAS PER SQUARE) \\ Actual Values - Printed on Alumina}

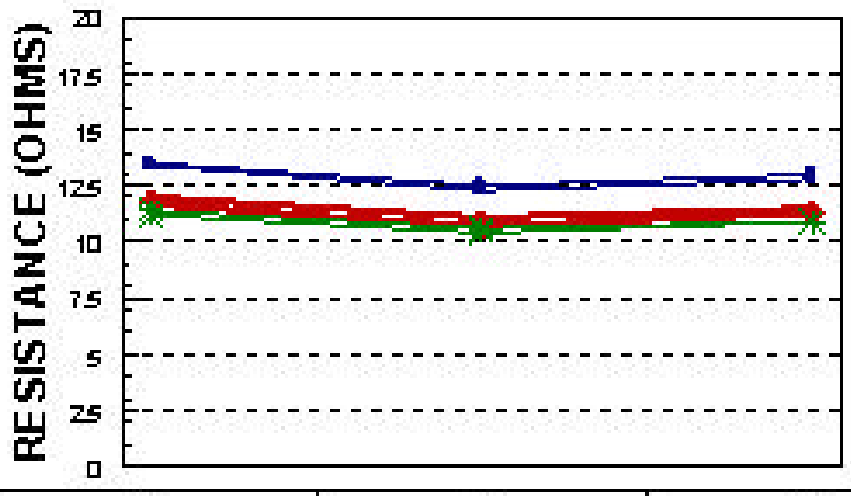

\begin{tabular}{|c|c|c|c|}
\hline RES ISTOR GEOMETRY & ומני & $m$ & m \\
\hline 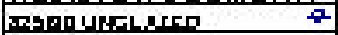 & 194 & 129 & 123 \\
\hline maporgharso & 123 & 122 & 100 \\
\hline 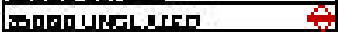 & $11, \mathrm{r}$ & 10,5 & 112 \\
\hline 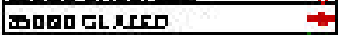 & 120 & 11,1 & 115 \\
\hline ArgODURFLERE & 112 & 10.4 & 102 \\
\hline grspo Gueren & 11. & 109 & 109 \\
\hline
\end{tabular}

Momind nomsird rest teras b 10 dms.

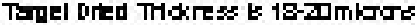

Emples fred InC ER1 1 (T

Figure C-5 


\section{NORMALIZED SHEET RESISTANCE}

DUPONT 2011(10 OHMS PER SQUARE)

Percent from Nomin al Normalized Resiztance - Printed on Alumina

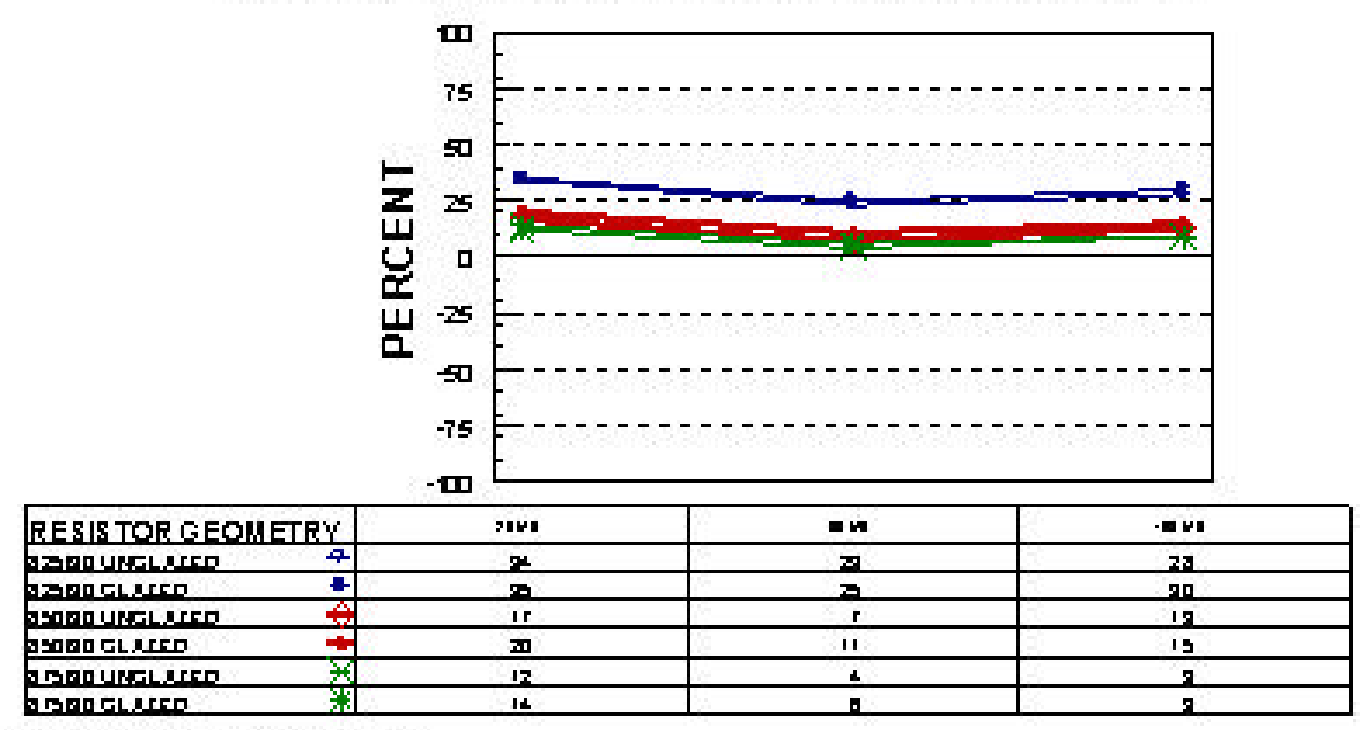

Moming nomsind rest tanc b 10 drms.

Tarpel brted THdkress b 18-70milars

Emples fred Inc Estit

\section{NORMALIZED SHEET RESISTANCE DUPONT 2011(10 OHMS PER SQUARE) \\ Actual Values - Printed on Alumina}

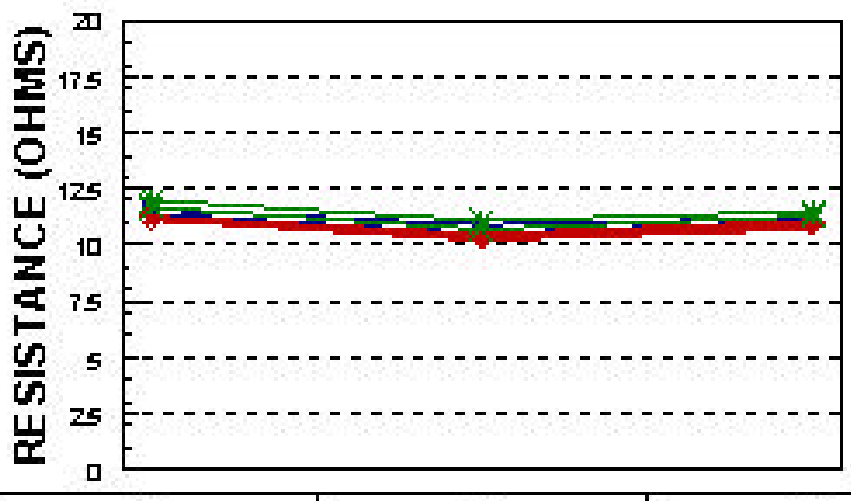

\begin{tabular}{|c|c|c|c|}
\hline RESISTORGEOMETRY & ועוני & $=\mathbf{n}$ & שv \\
\hline 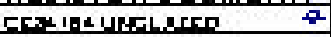 & $11 \leqslant$ & 20 & 111 \\
\hline 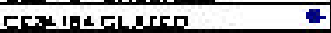 & 118 & 109 & 112 \\
\hline 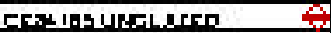 & 112 & $10 x$ & 110 \\
\hline 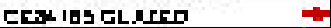 & $\| 2$ & פם & I \\
\hline 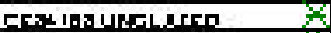 & $11, r$ & $10, r$ & 112 \\
\hline 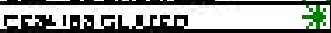 & $12 \pi$ & 11,1 & 113 \\
\hline
\end{tabular}

Maming namelird rest tans b $10 \mathrm{dm}$.

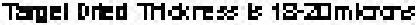

Emples fred wi hagroprote

Figure C-7 


\section{NORMALIZED SHEET RESISTANCE}

DUPONT 2011(10 OHMS PER SQUARE)

Percent from Nomin al Normalized Resiztance - Printed on Alumina

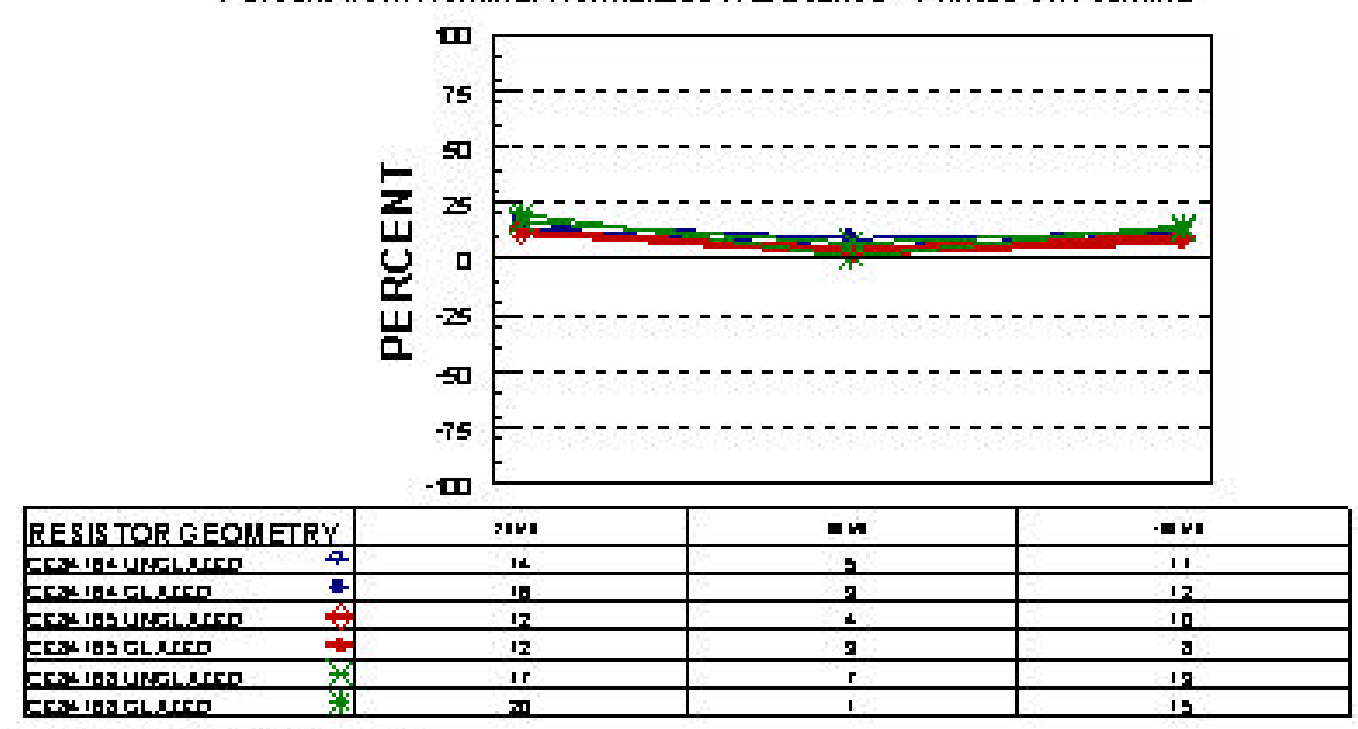

Momind nomsind rest tans b $10 \mathrm{dms}$.

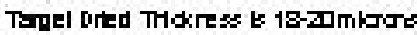

Emples fred Inc Estit

\section{THICKNESS \& RESISITIVITY COMPARISON DUPONT 2011(10 OHMS PER SQUARE) \\ Actual Values - Printed on Alumina}

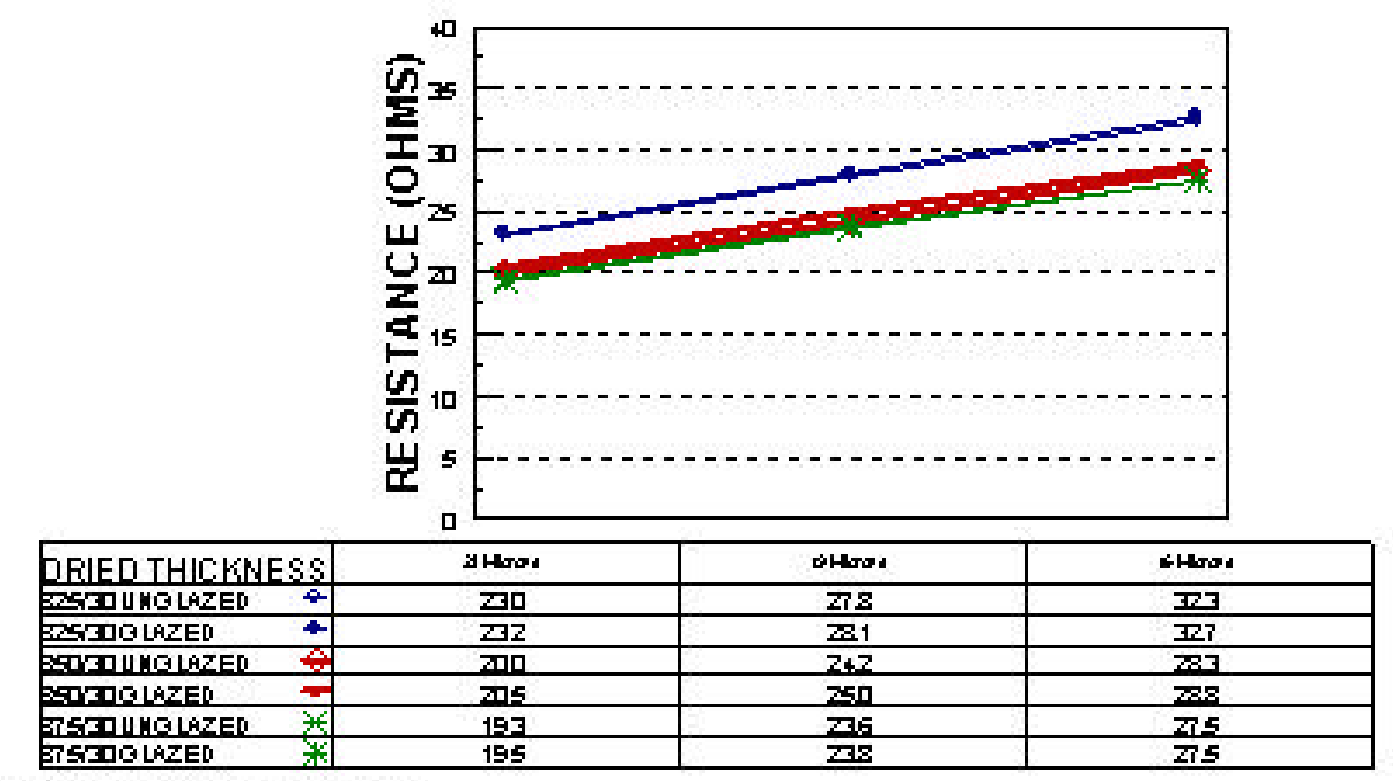

Tapel orted THdkres b 18-7mmars

Figure C-9 


\section{THICKNESS \& RESISITIVITY COMPARISON}

\section{DUPONT 2011(10 OHMS PER SQUARE)}

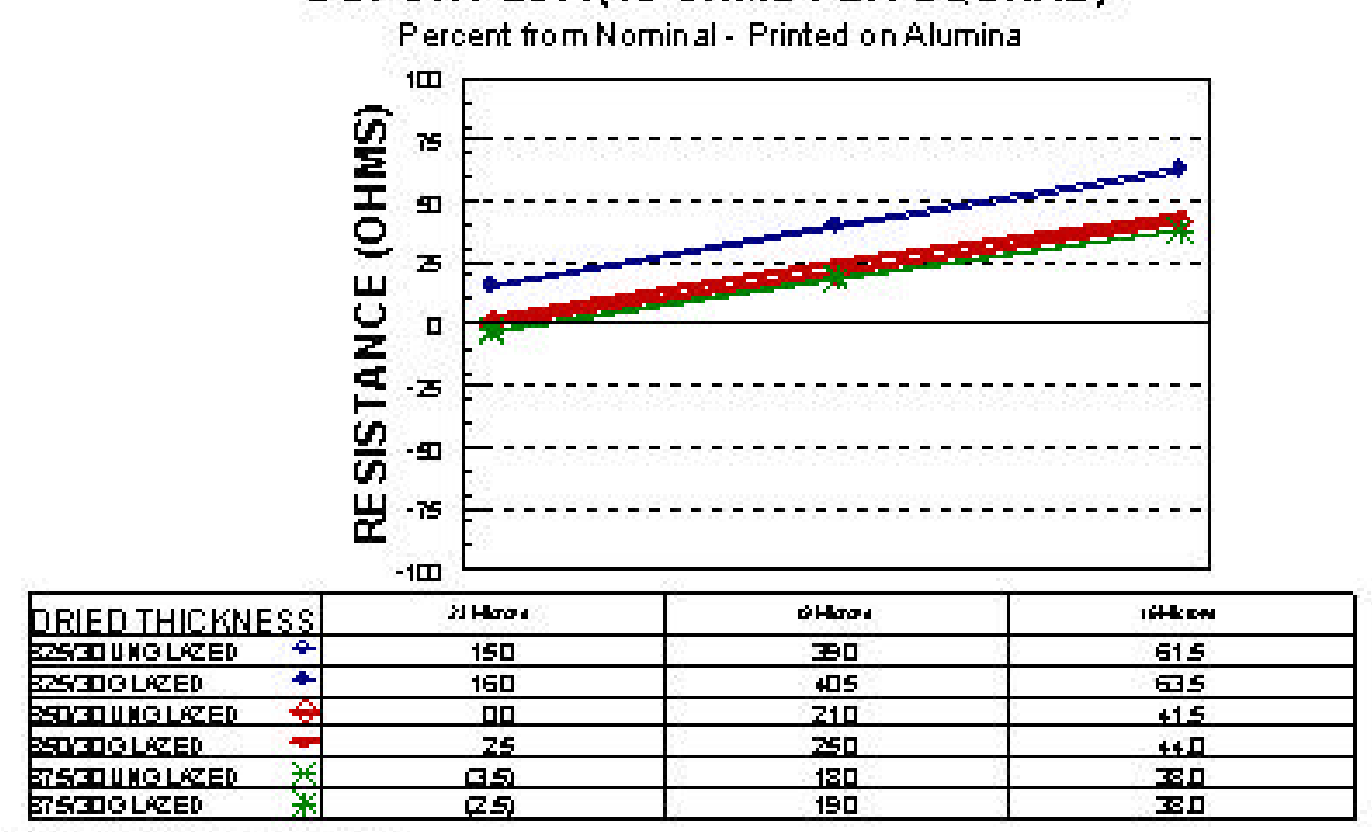

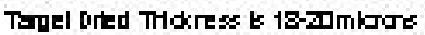

Figure C-10

\section{THICKNESS RELATIONSHIP \\ DUPONT 2011(10 OHMS PER SQUARE)}

Printed on Alumina

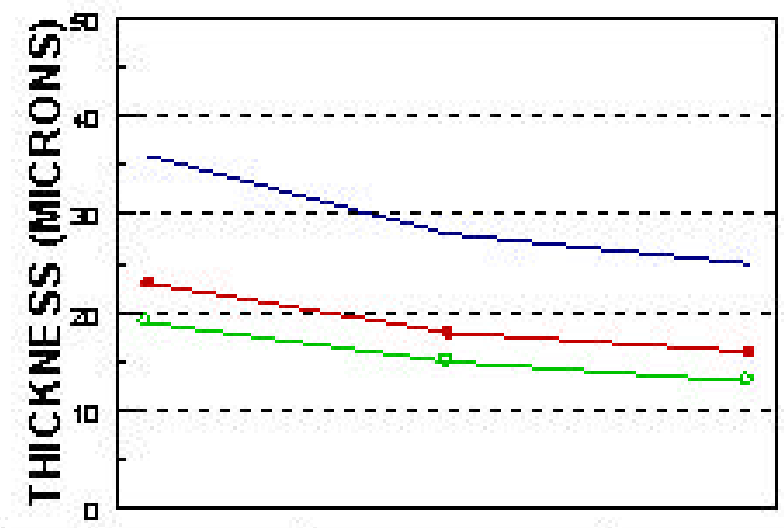

\begin{tabular}{|c|c|c|c|}
\hline GEOHETRY & $25 \mathrm{MIL}$ & s刀 MIL & 1⿴囗十ा 씨 \\
\hline WE THCKNESS - & 36 & 28 & 25 \\
\hline DRIFD THICKNESS - & 23 & 18 & 16 \\
\hline EIRED THICKNESS - & 19 & 15 & 13 \\
\hline
\end{tabular}

Tagel orted Thdoress b 18-20migros

Figure C-11 


\section{APPENDIX D}

DU PONT 2021 RESISTOR PRINTING DATA

$$
\text { (100 Ohm) }
$$

\section{FIRING PROFILE SENSITIMTY DUPONT 2021(100 OHMS PER SQUARE)}

Actual Values - Printed on Alumina

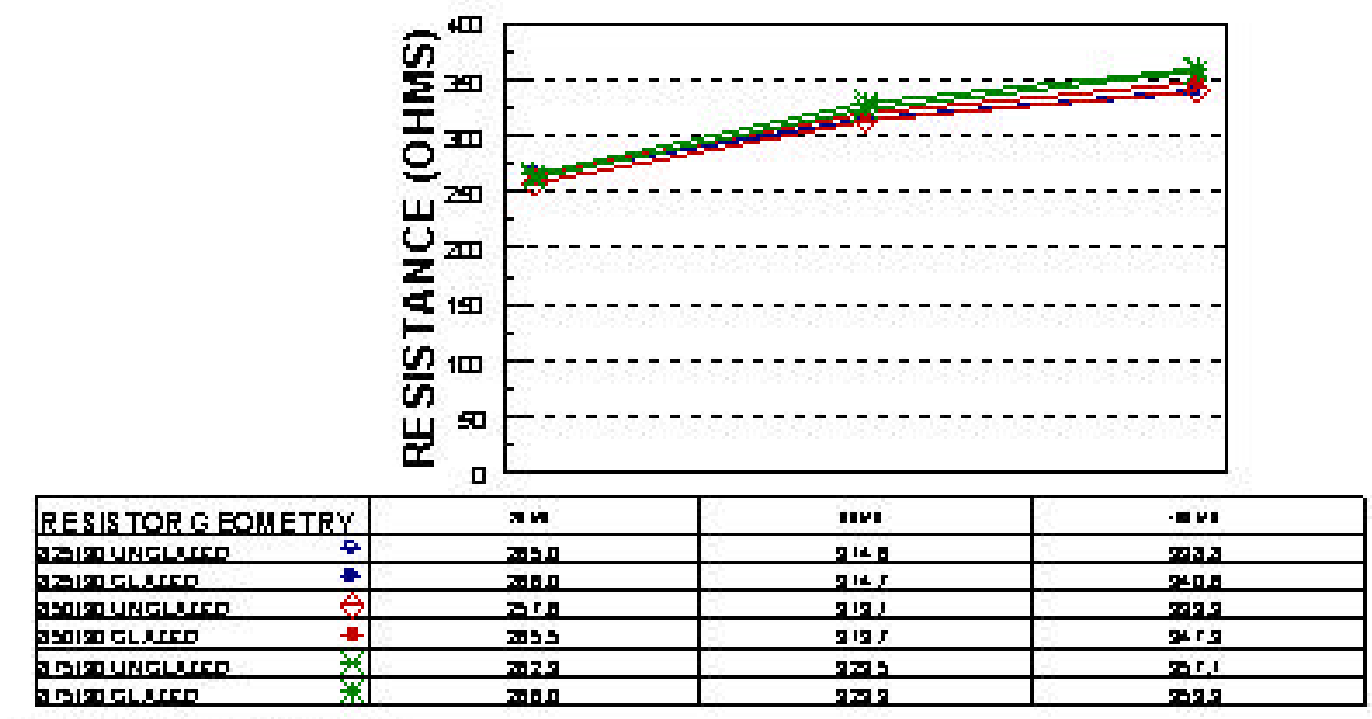

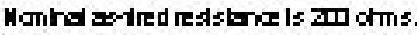

Tagel orted THdkres b 18-0]misus

Emple fredinc Est 19

Figure D-1 


\section{FIRING PROFILE SENSITIVTY \\ DUPONT 2021(100 OHMS PER SQUARE)}

Percent fr om Nominal Values - P rinted on Alumina

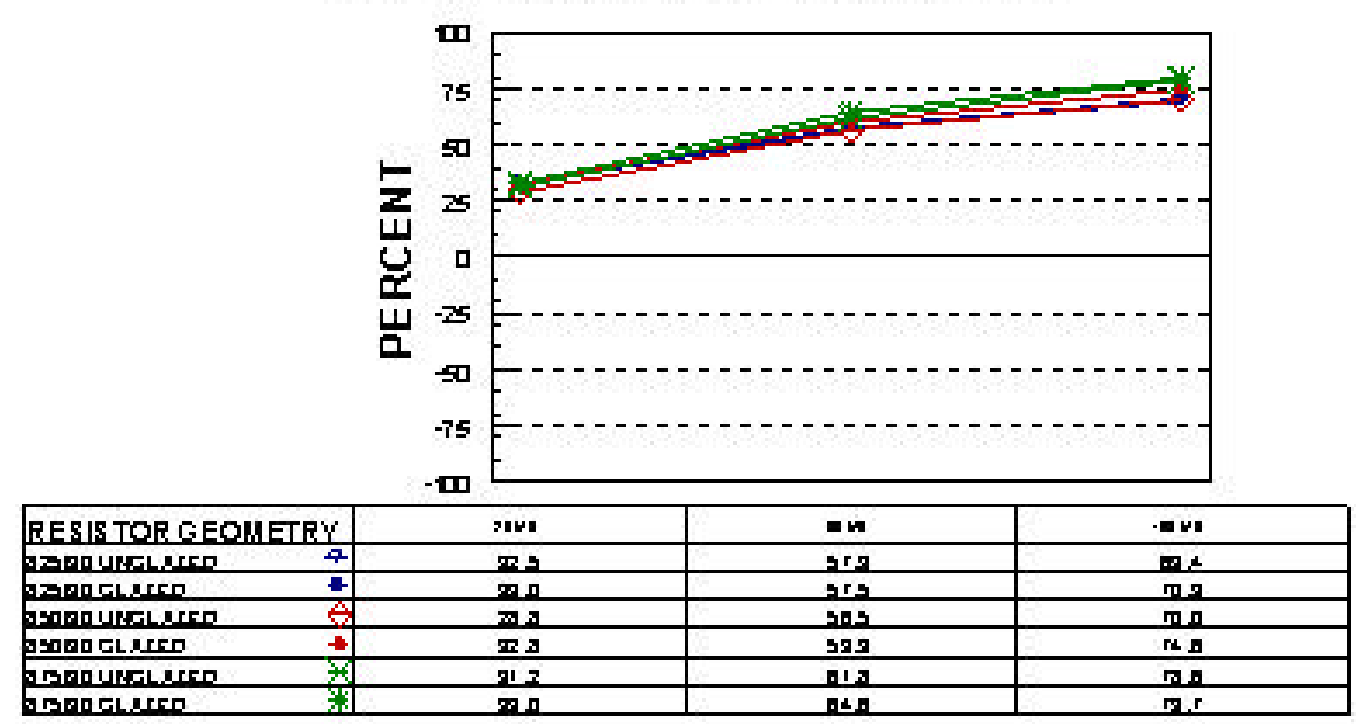

Monind ayired resstora is an orms.

Tarpel brted THdkress b 18-70milars

Emples fred Inc Eat 1 (T

\section{FURNACE SENSITIVTYY} DUPONT 2021(100 OHAS PER SQUARE)

Actual Values - Printed on Alumina

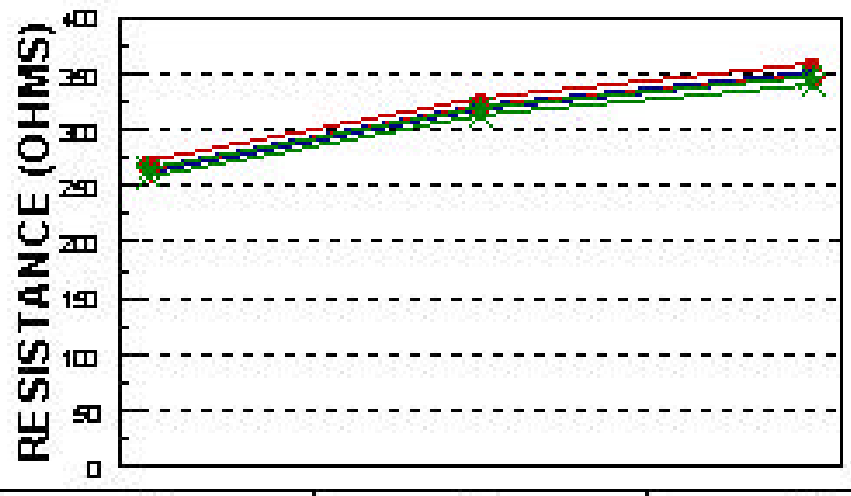

\begin{tabular}{|c|c|c|c|}
\hline RESISTOR G EOMETRY & $\boldsymbol{x} \boldsymbol{n}$ & uni & m w \\
\hline 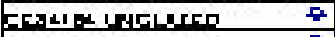 & mn & gतn & $=0$ \\
\hline 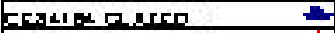 & man & nखा & 298 \\
\hline 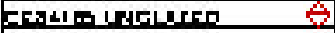 & nn & 9210 & 2010 \\
\hline 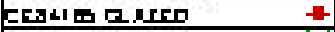 & $2 \mathrm{r} 2 \mathrm{~s}$ & $2 \times 2$ & 20 \\
\hline 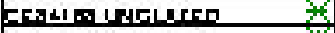 & $=\pi$ & ספופ & 200 \\
\hline 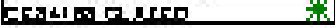 & בה & gur & $2 \mathrm{rg}$ \\
\hline
\end{tabular}

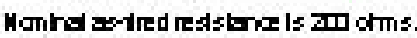

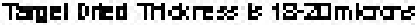
amples fred wi hagugnote 


\section{FURNACE SENSITIVITY}

\section{DUPONT 2021(100 OHAS PER SQUARE)}

Percent fr om Nominal Values - P rinted on Alumina

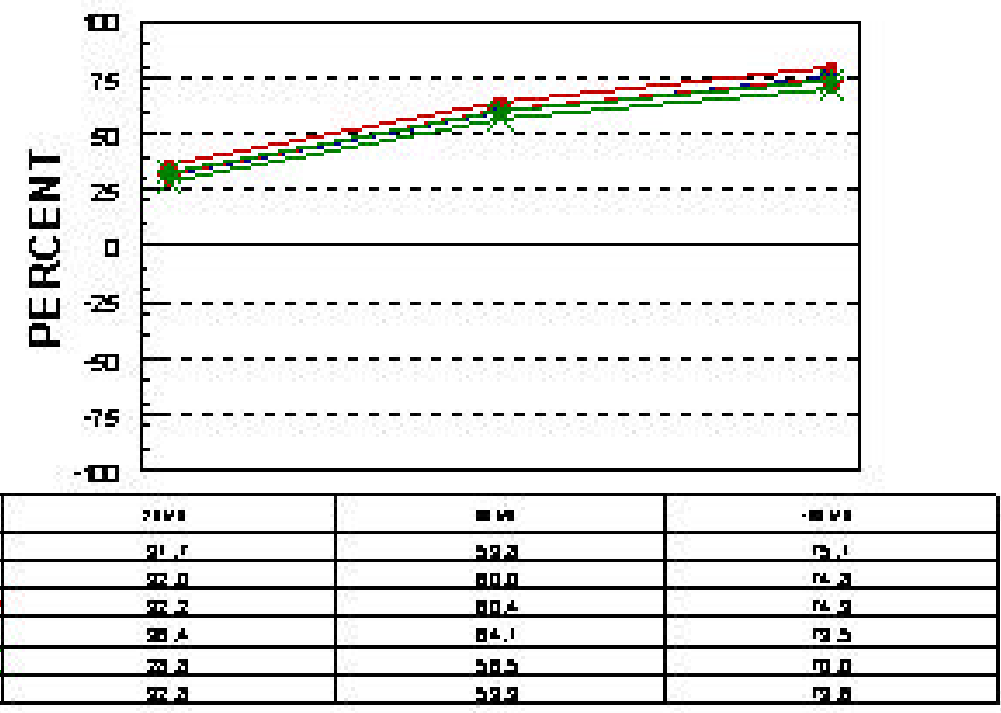

Momind asyred reststarc is an orms.

Taplel orted Thdoress b 18-30miages

Emples fird withagroprote

\section{NORMALIZED SHEET RESISTANCE DUPONT 2021(100 OHMS PER SQUARE)}

Actual Values - Printed on Alumina

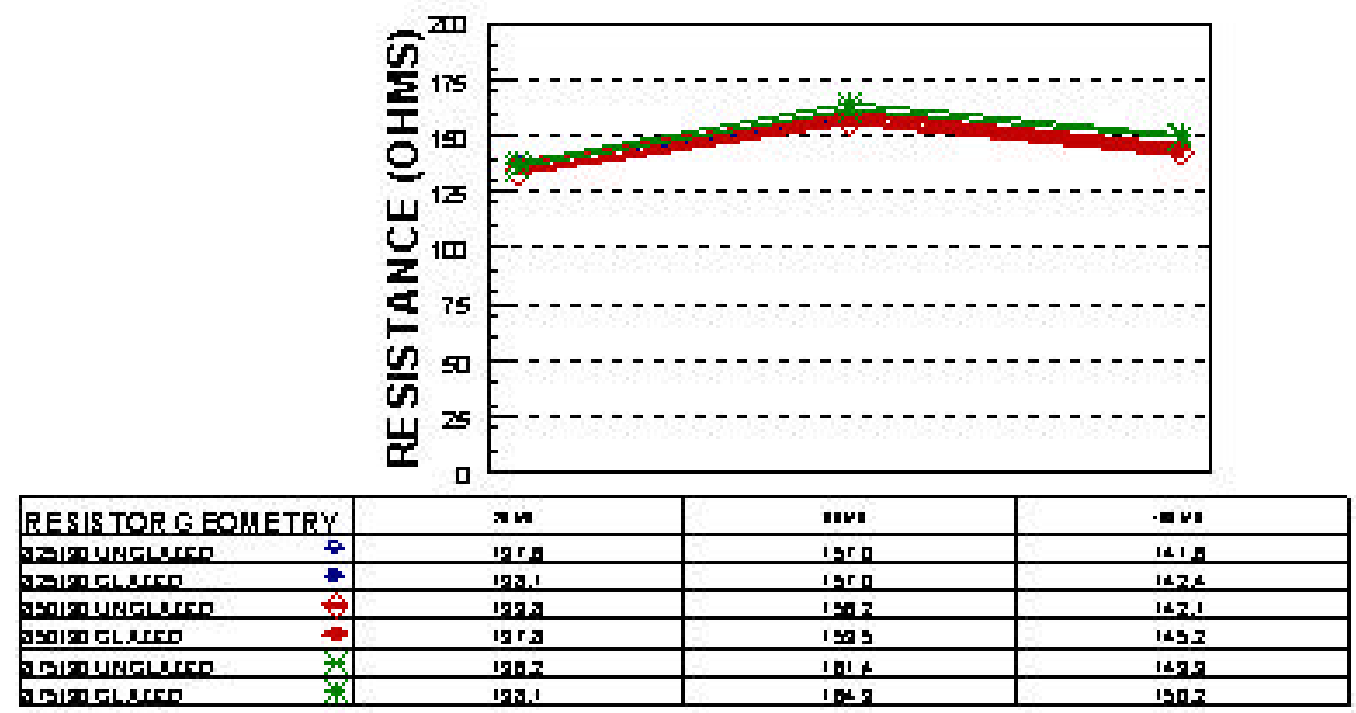

Manind nomelred rest tanc to 1 motms.

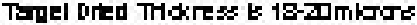

Emples fred InC ER 1 (I

Figure D-5 


\section{NORMALIZED SHEET RESISTANCE}

DUPONT 2021(100 OHMS PER SQUARE)

Percent from Nomin al Normalized Resiztance - Printed on Alumina

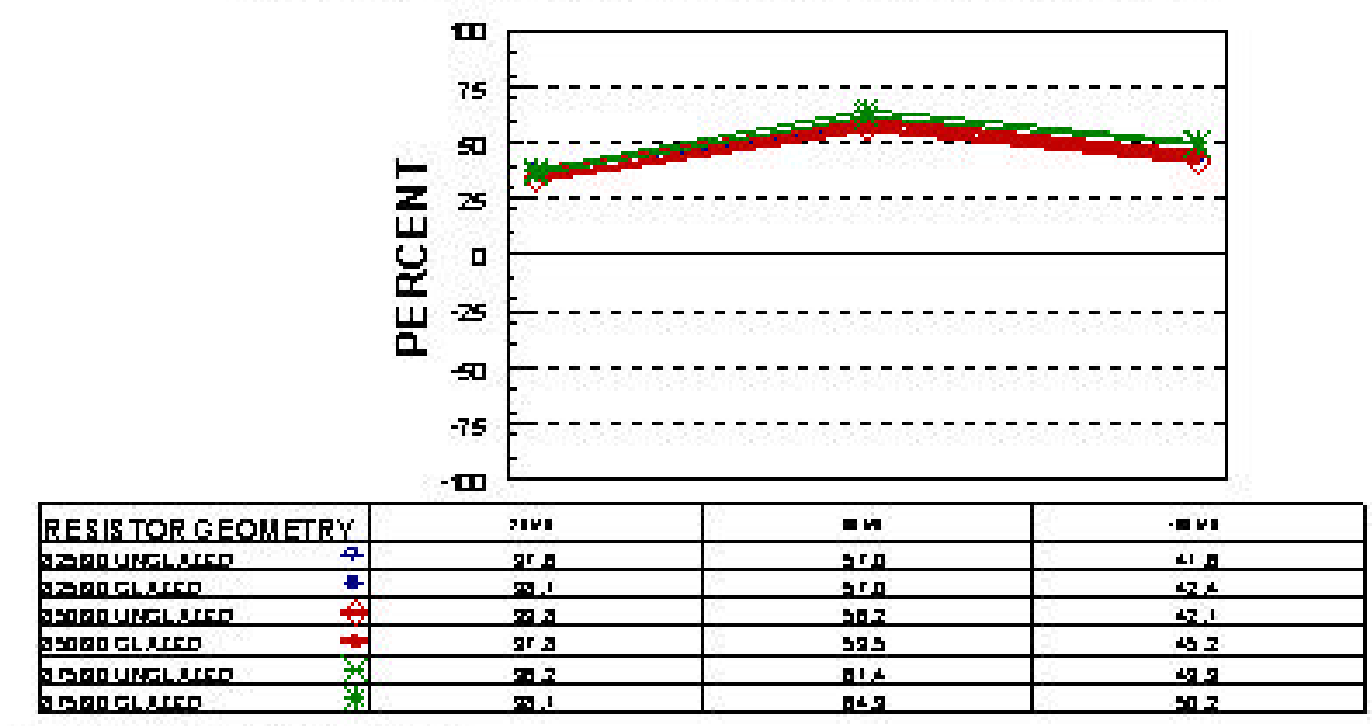

Moming namsind rest tanc b 1 morms.

Tarpel brted THdkress b 18-70milars

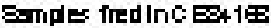

\section{NORMALIZED SHEET RESISTANCE DUPONT 2021(100 OHMS PER SQUARE)}

Actual Values - Printed on Alumina

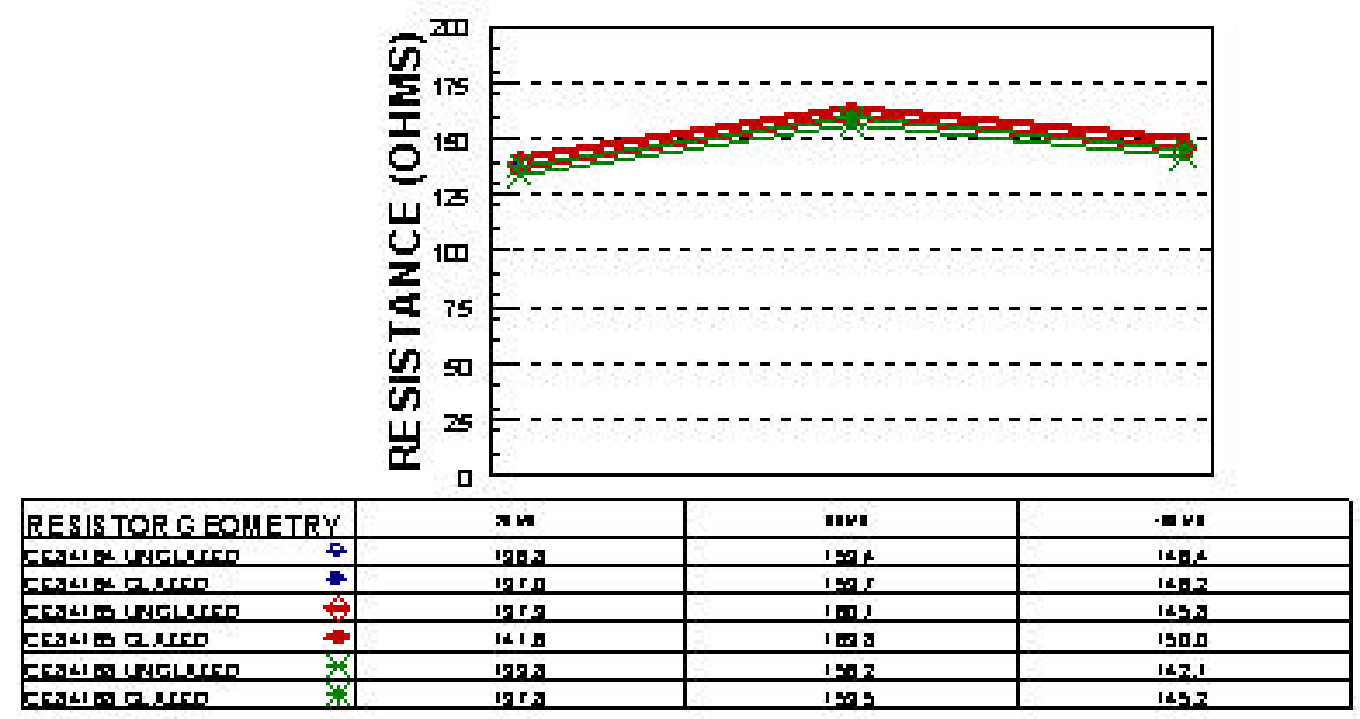

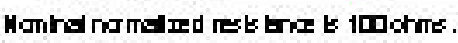

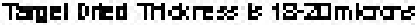

smples fred wi hagroprote

Figure D-7 


\section{NORMALIZED SHEET RESISTANCE}

DUPONT 2021(100 OHMS PER SQUARE)

Percent from Nomin al Normalized Resiztance - Printed on Alumina

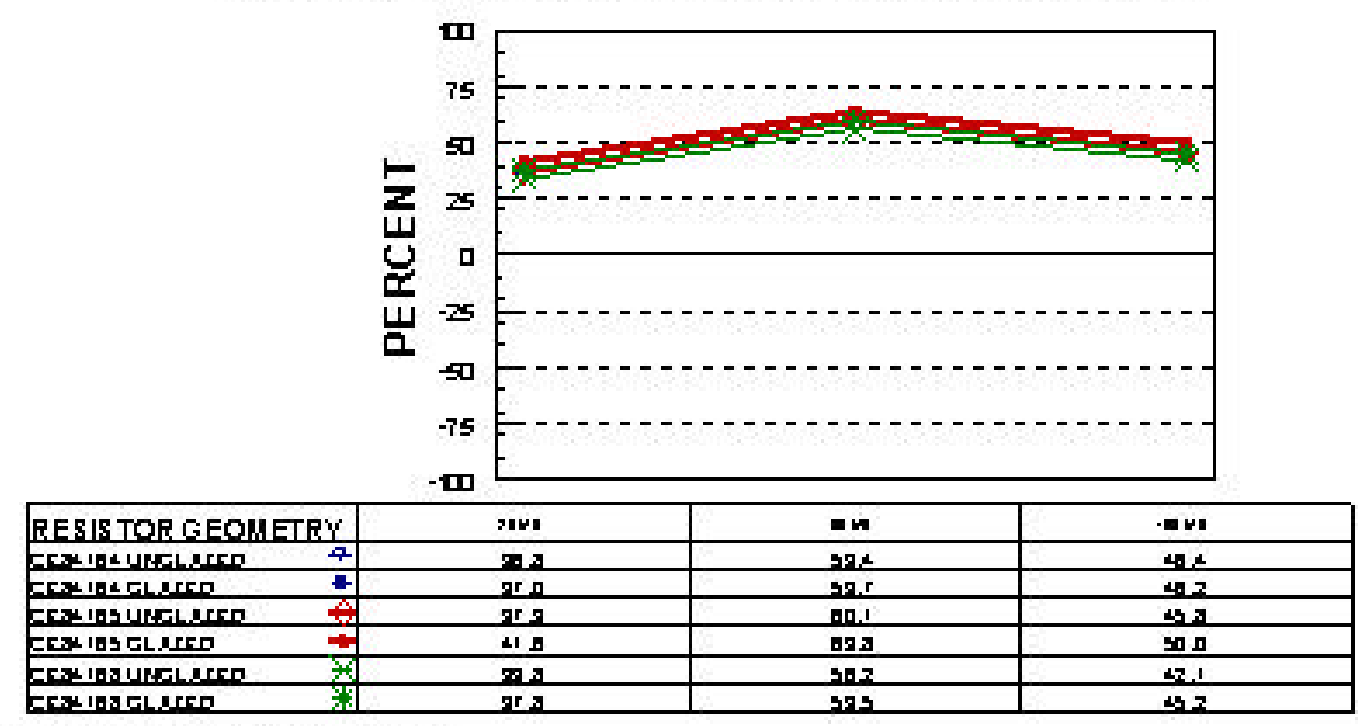

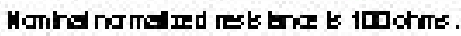

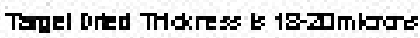

Emple fredinc EAt 1 (T

\section{THICKNESS \& RESISITIVITY COMPARISON DUPONT 2021(100 OHMS PER SQUARE)}

Actual Values - Printed on Alumina

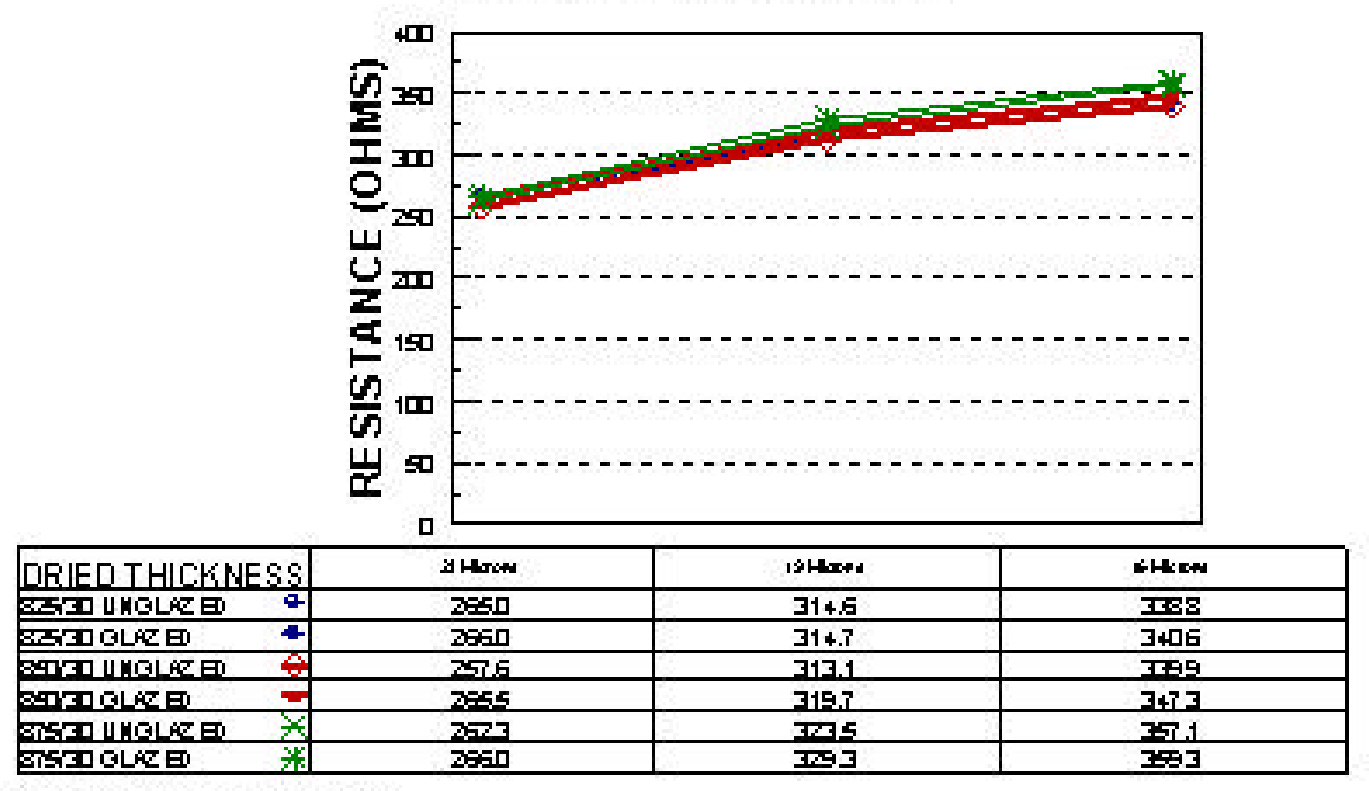

Tagel orted THdkres b 18-0]miars

Figure D-9 


\section{THICKNESS \& RESISITIVITY COMPARISON}

\section{DUPONT 2021(100 OHASS PER SQUARE)}

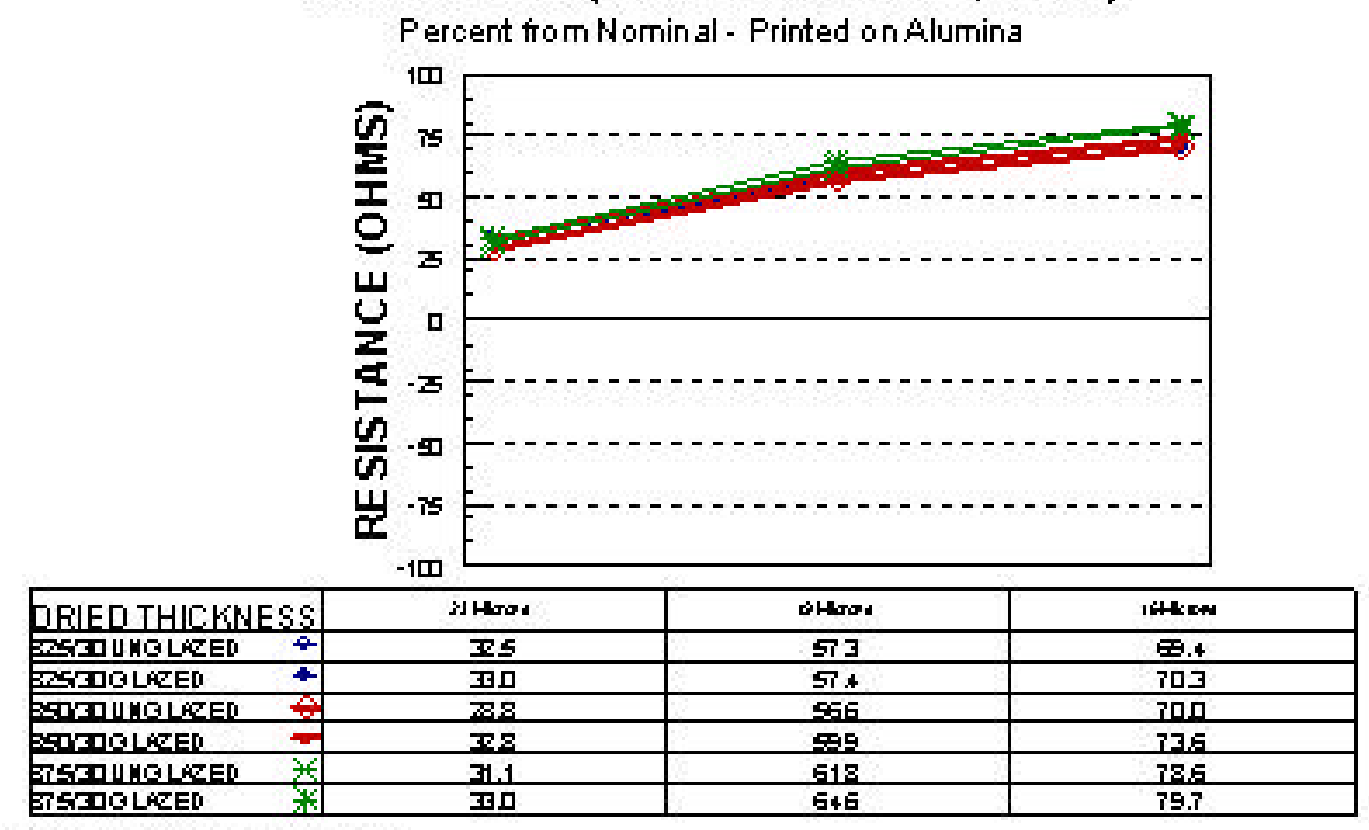

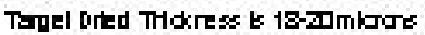

Figure D-10

\section{THICKNESS RELATIONSHIP DUPONT 2021(100 OHMS PER SQUARE)}

Printed on Alumina

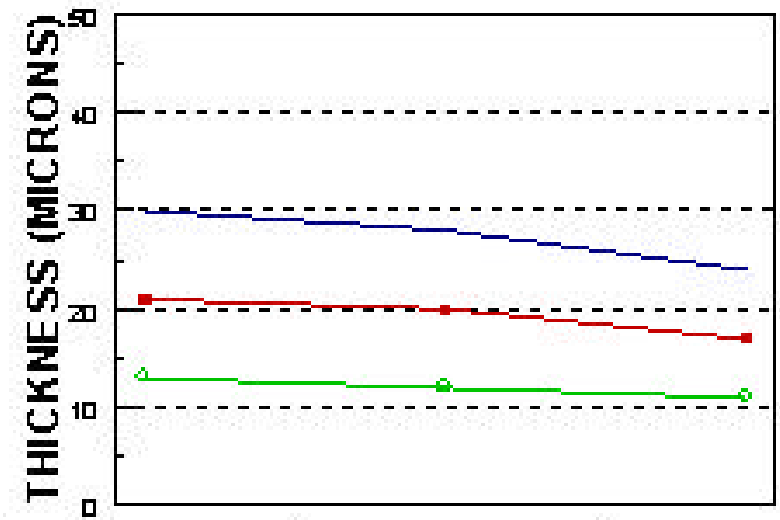

\begin{tabular}{|c|c|c|c|}
\hline GEOMETRY & 25 MIL & s MIL & 1 m MIL \\
\hline MET THICKNESS & 30 & 28 & 24 \\
\hline DRIFD THICKNESS - & 21 & 20 & 17 \\
\hline EIRED THICKNESS & 13 & 12 & 11 \\
\hline
\end{tabular}

Tapel orted Thdoress b 18-DImigas

Figure D-11 
APPENDIX E

DU PONT 2031 RESISTOR PRINTING DATA

$(1 \mathrm{~K} \mathrm{Ohm})$

\section{FIRING PROFILE SENSITIVTYY DUPONT 2031(1000 OHMS PER SQUARE)}

Actual Values - Printed on Alumina

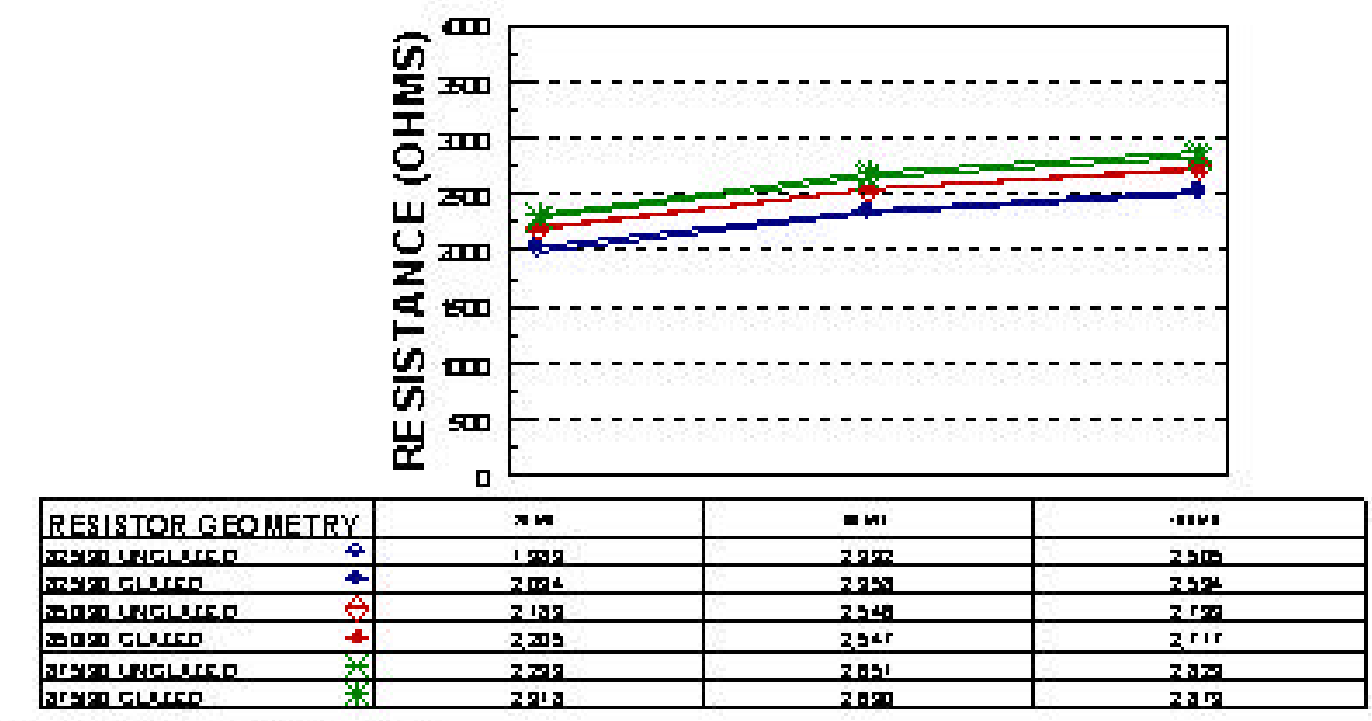

Momind av-1red retstanx is alm dms.

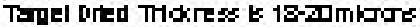

Emples fred inc Est 1 (T

Figure E-1 


\section{FIRING PROFILE SENSITIVTTY \\ DUPONT 2031(1000 OHMS PER SQUARE)}

Percent fr om Nominal Values - P rinted on Alumina

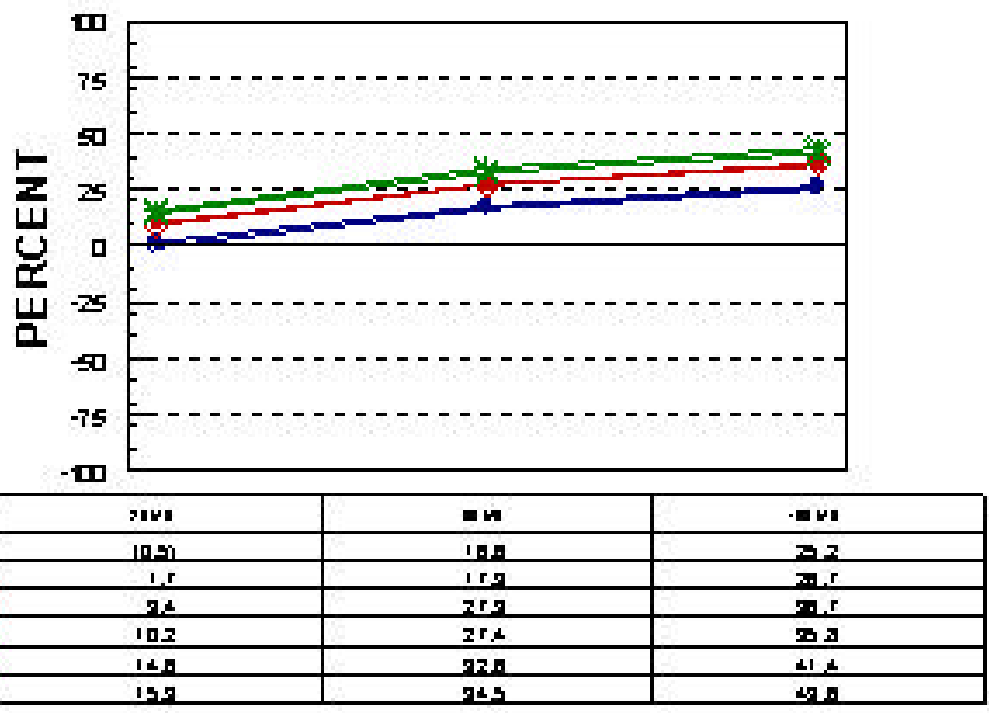

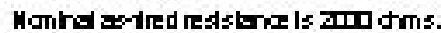

Tapel bited THdkress b 18-201mibars

Emples fird InC E\& 1 (I

Figure E-2

FURNACE SENSITIVITY

DUPONT 2031(1000 OHMS PER SQUARE)

Actual Values - Printed on Alumina

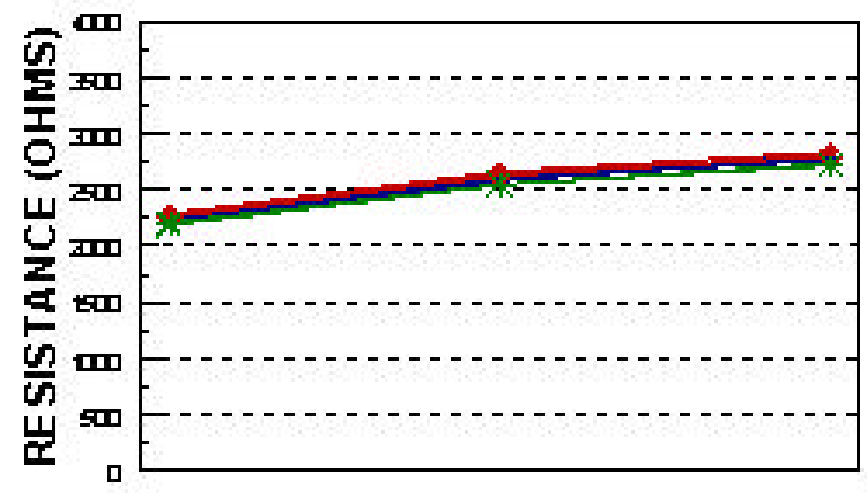

\begin{tabular}{|c|c|c|c|}
\hline RESISTOR GEOMETRY & an & $=$ mi & - anvi \\
\hline 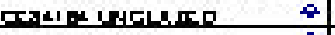 & $7=2$ & 2.20 & $\mathrm{zrm}$ \\
\hline 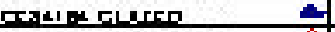 & $2 \pi 0$ & 250 & $2 \mathrm{rz}$ \\
\hline [x+1\% & $2 \pi$ & $202 \mathrm{r}$ & 235 \\
\hline 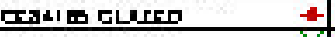 & 2표 & הם & 239 \\
\hline 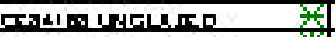 & 2132 & 254 & $2 \mathrm{rm}$ \\
\hline 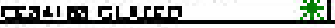 & 2n: & $2.34 r$ & $2 \mathrm{rir}$ \\
\hline
\end{tabular}

Manind ayred retsterce is and dms.

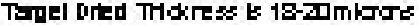

Emples fred whagroprote

Figure E-3 


\section{FURNACE SENSITIVITY}

\section{DUPONT 2031(1000 OHAS PER SQUARE)}

Percent fr om Nominal Values - P rinted on Alumina

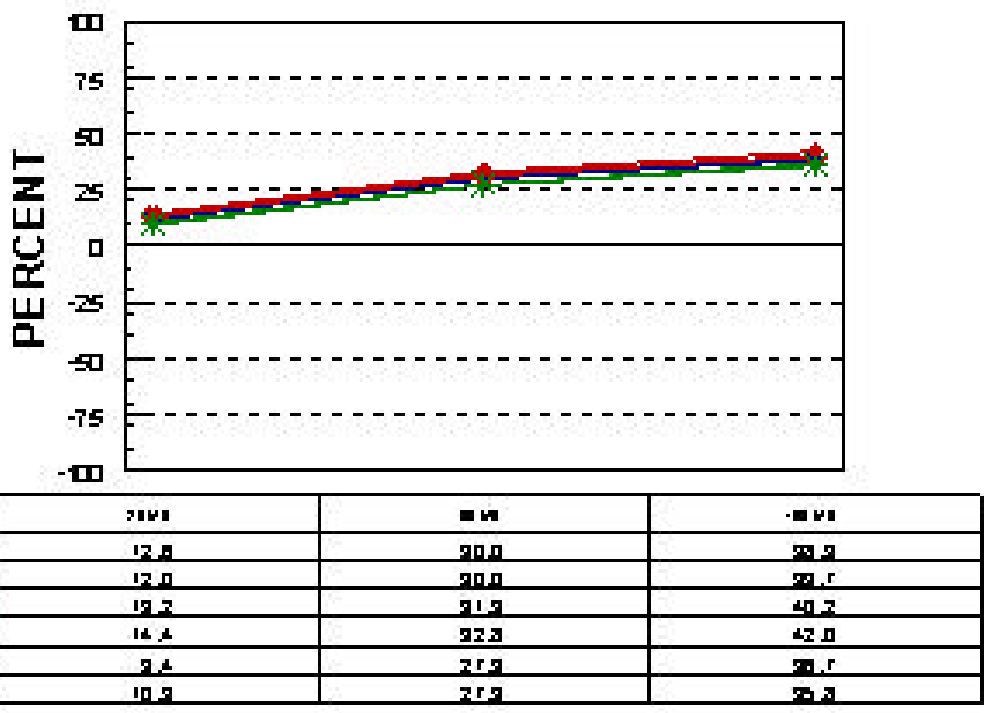

Monind as-1red retstorx is and dms.

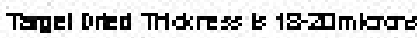

ample fred wh hagnoprote

NORMALIZED SHEET RESISTANCE

DUPONT 2031(1000 OHAS PER SQUARE)

Actual Values - Printed on Alumina

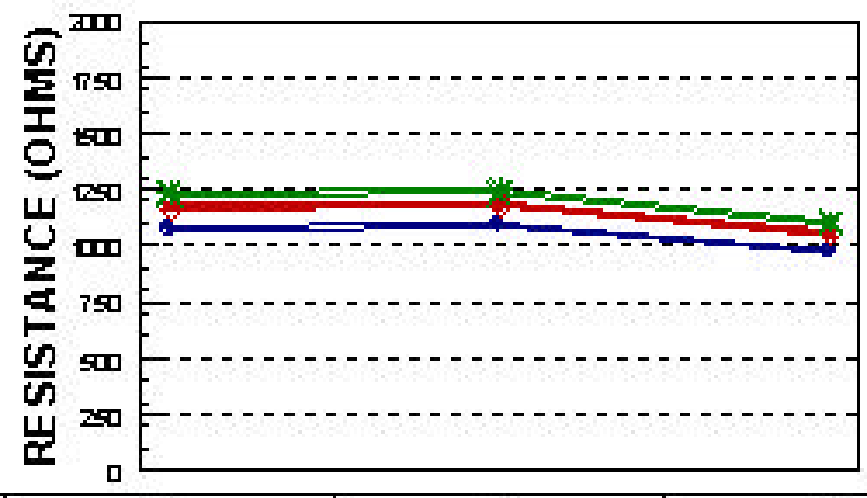

\begin{tabular}{|c|c|c|c|}
\hline RESISTOR GEOMETRY & an & 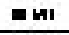 & ניוני. \\
\hline 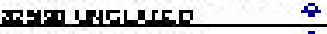 & 100 & $10 \mathrm{ng}$ & $2 \pi$ \\
\hline man cursen & $1 \mathrm{man}$ & $10 \mathrm{~m}$ & 9.2 \\
\hline 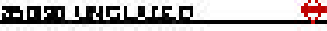 & $1,1,1$ & 113 & $1 \mathrm{ng}$ \\
\hline man GLبع & 1,19 & $1 \mathrm{ar}$ & 1,02 \\
\hline 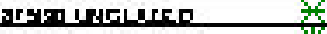 & 1 표 & 1280 & 100 \\
\hline
\end{tabular}

Manirs nomelrd rest tanc to 1 molms.

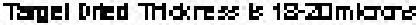

Emples fred inc Est 1 (T

Figure E-5 


\section{NORMALIZED SHEET RESISTANCE}

DUPONT 2031(1000 OHMS PER SQUARE)

Percent from Nomin al Normalized Resistance - Printed on Alumina

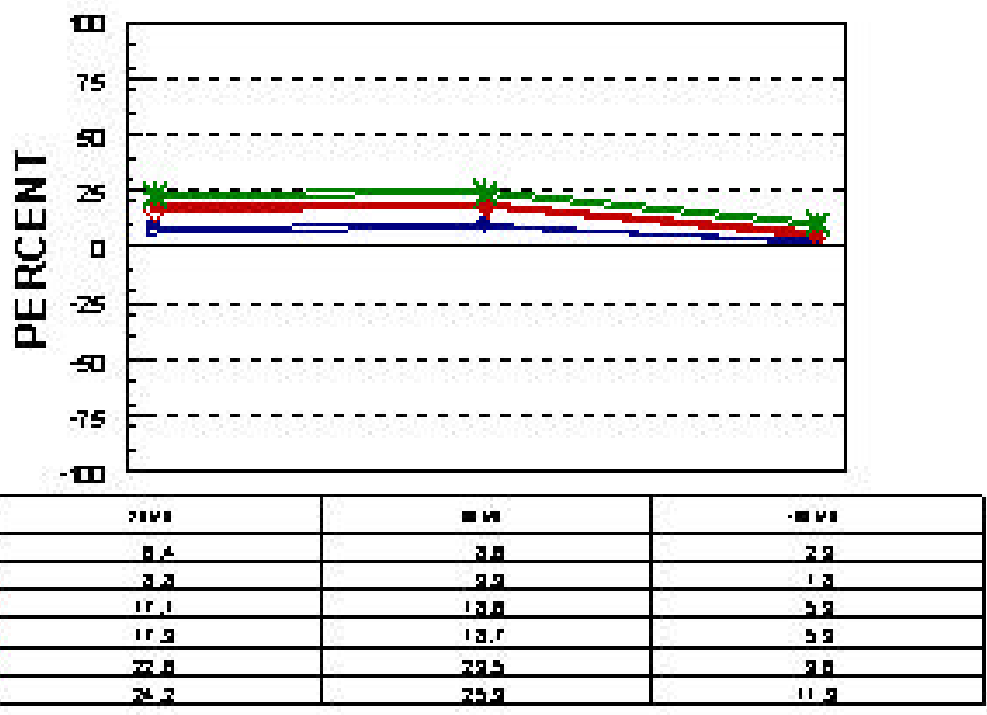

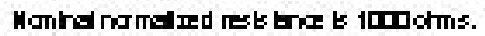

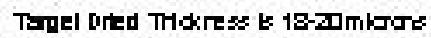

Emples fred InC E* 19

\section{NORMALIZED SHEET RESISTANCE DUPONT 2031(1000 OHMS PER SQUARE)}

Actual Values - Printed on Alumina

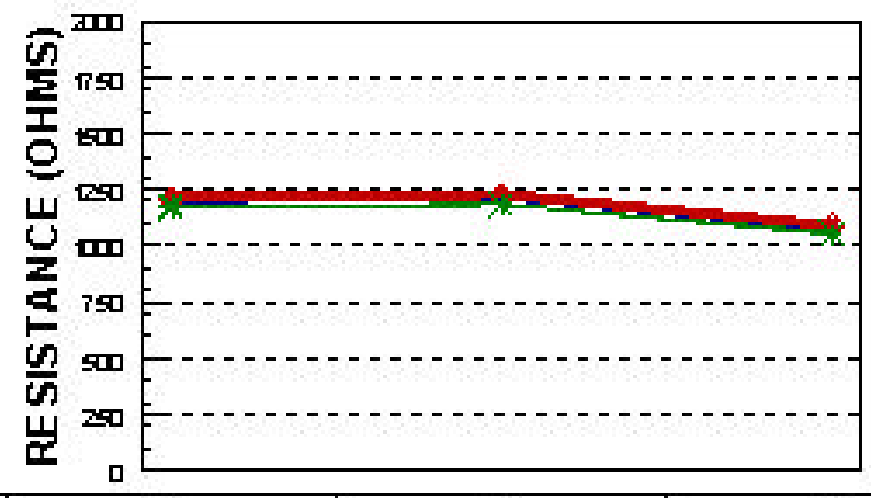

\begin{tabular}{|c|c|c|c|}
\hline RESISTOR GEOMETRY & an & $=m_{1}$ & ישוח \\
\hline 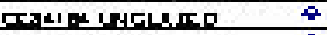 & 1 .914 & 1211 & ع \\
\hline 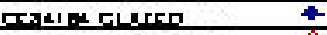 & 1.98 & 1210 & $10 \mathrm{~m}$ \\
\hline 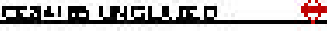 & 1210 & $12 \pi$ & 1035 \\
\hline 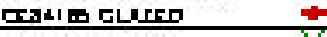 & 1,72 & $1,29 \mathrm{r}$ & I. \\
\hline 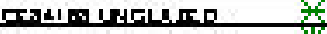 & $1, \mathbf{r}$ & 118 & $10 \mathrm{an}$ \\
\hline
\end{tabular}

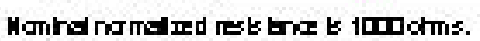

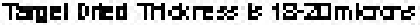

somples fied whagroprote

Figure E-7 


\section{NORMALIZED SHEET RESISTANCE}

DUPONT 2031(1000 OHAS PER SQUARE)

Percent from Nomin al Normalized Resistance - Printed on Alumina

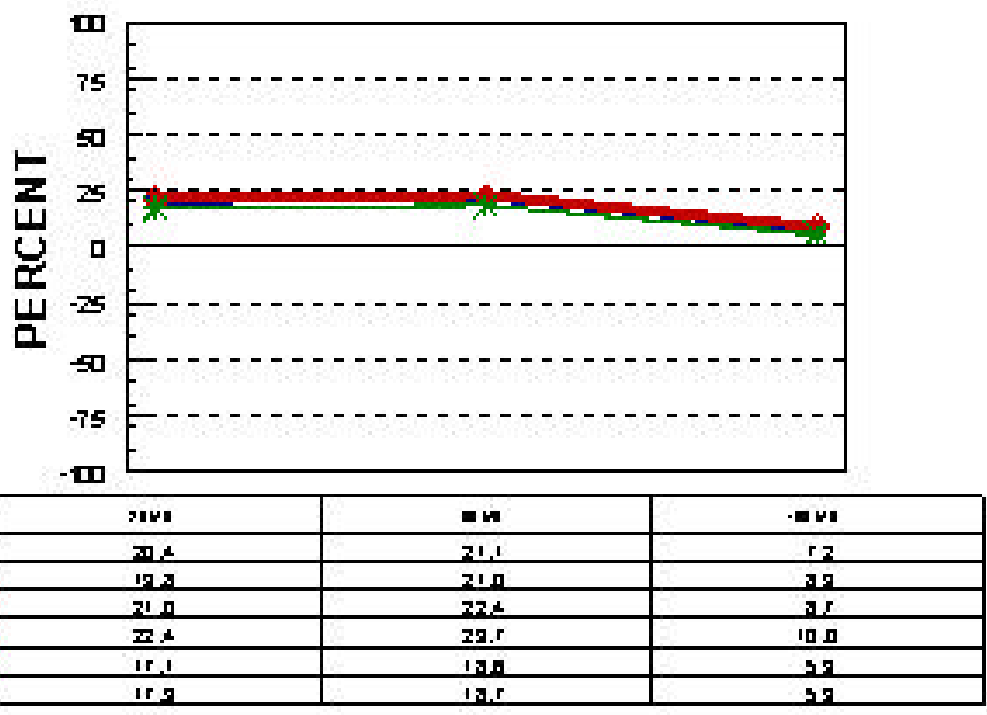

Monirs nomsird rest tor to 1 moms.

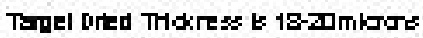

Emples fred InC Estit

\section{THICKNESS \& RESISITIVITY COMPARISON DUPONT 2031(1000 OHMS PER SQUARE)}

Actual Values - Printed on Alumina

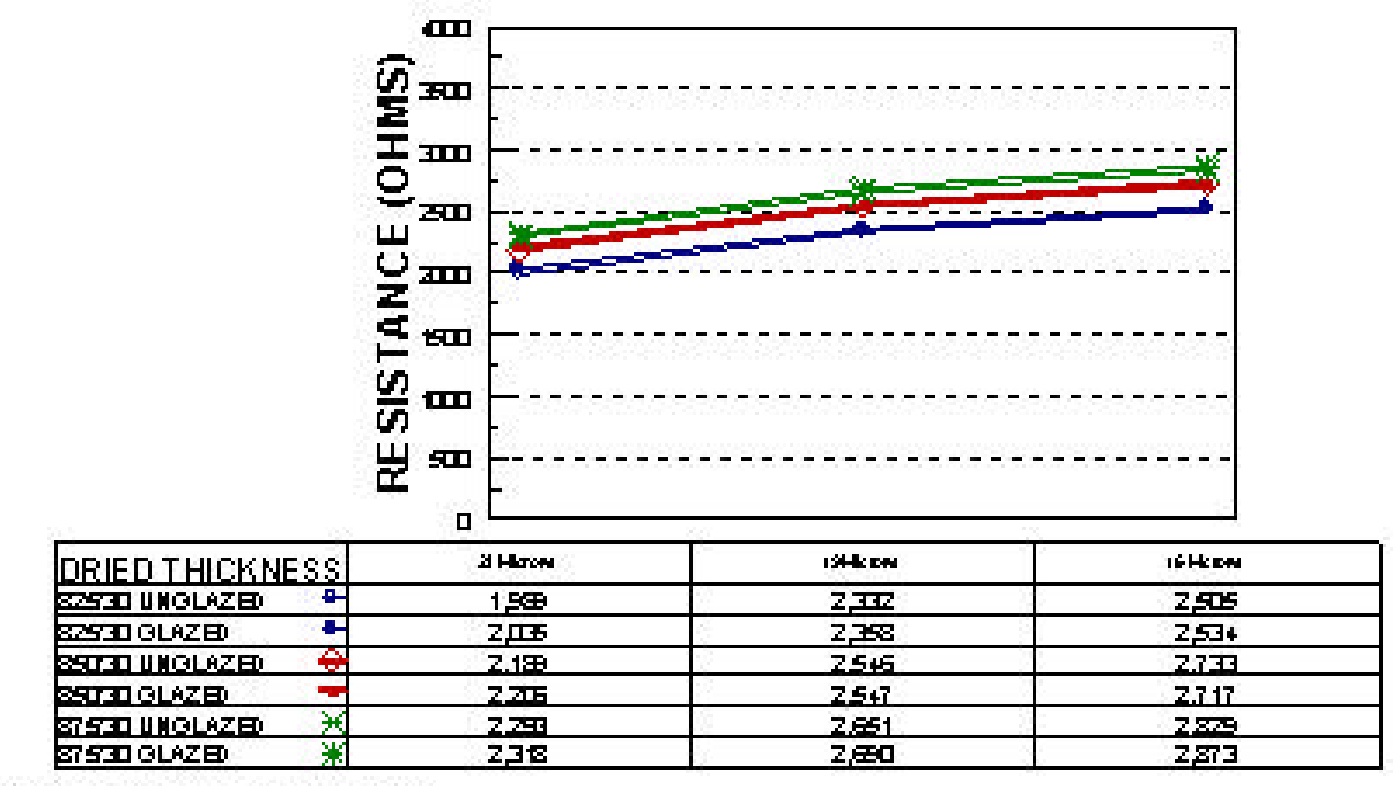

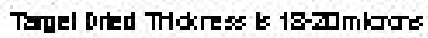

Figure E-9 


\section{THICKNESS \& RESISITIVITY COMPARISON}

\section{DUPONT 2031(1000 OHMS PER SQUARE)}

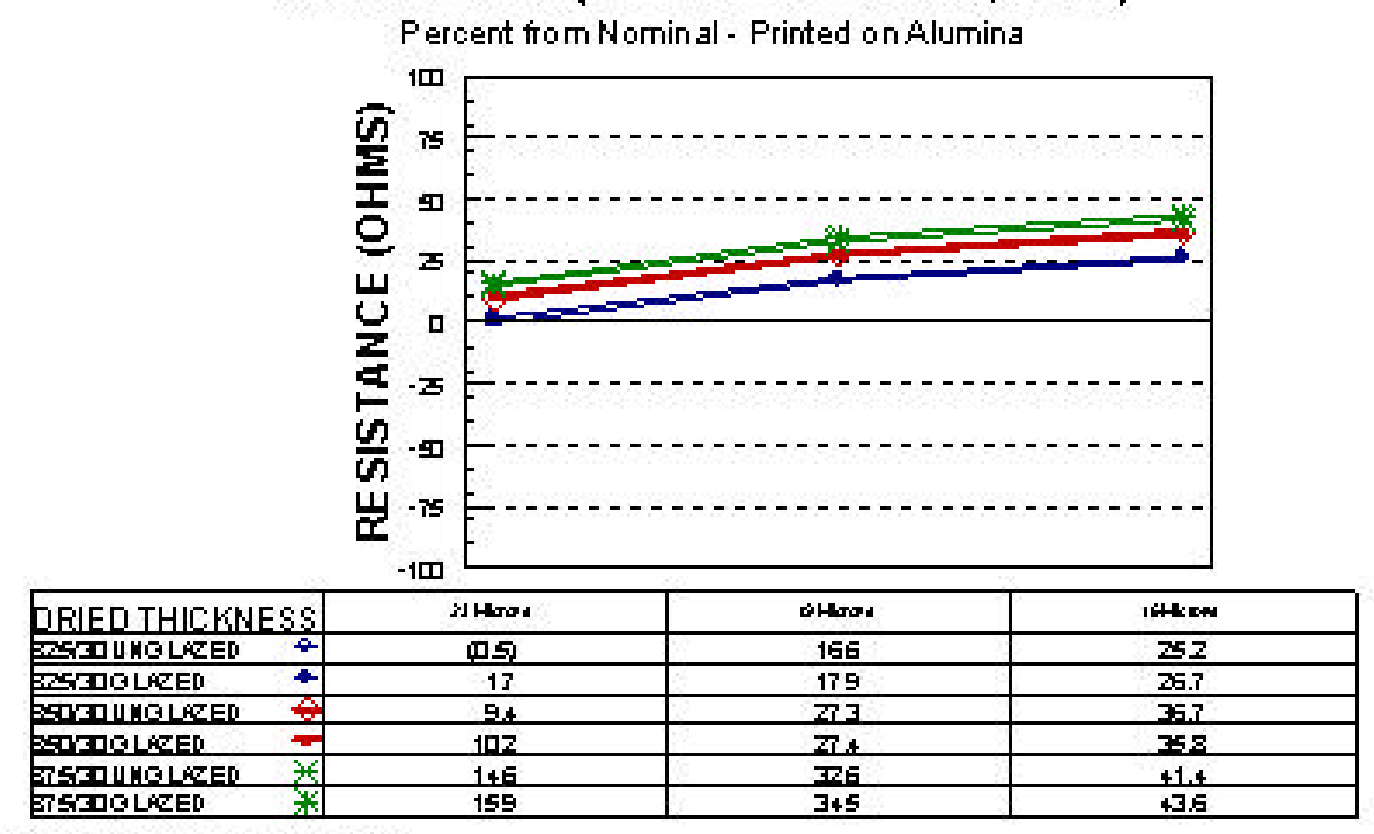

\section{THICKNESS RELATIONSHIP \\ DUPONT 2031(1000 OHMS PER SQUARE)}

Printed on Alumina

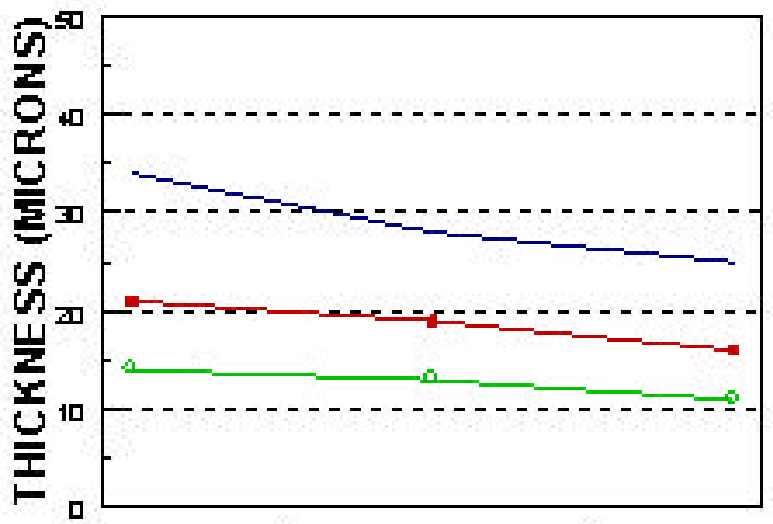

\begin{tabular}{|c|c|c|c|}
\hline GEOMETRY & 25 MIL & 刃o MIL & 1⿴囗十 ML \\
\hline MET THICKNESS & 34 & 28 & 25 \\
\hline DEIFD THICKNESS - & 21 & 19 & 16 \\
\hline EIRED THICKNIESS & 14 & 13 & 11 \\
\hline
\end{tabular}

Tagel orted THdores b 18-0Imiaros

Figure E-11 
DU PONT 2041 RESISTOR PRINTING DATA

(10K Ohm)

\section{FIRING PROFILE SENSITIVITY DUPONT 2041(10K OHMS PER SQUARE)}

Actual Values - Printed on Alumina

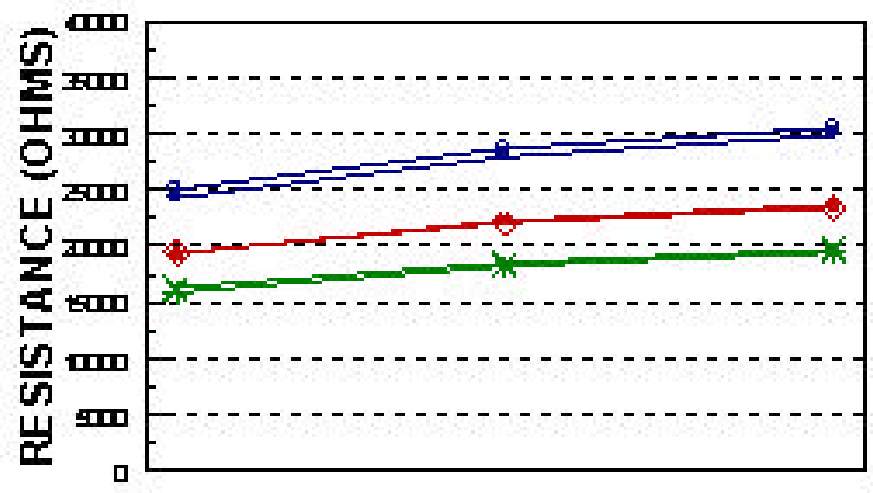

\begin{tabular}{|c|c|c|c|}
\hline RESISTORGEOMETRY & $\boldsymbol{x} \mathbf{n}$ & Iuvi & -ava \\
\hline 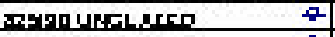 & =0rs & $\mathrm{mrnz}$ & מחנרת \\
\hline 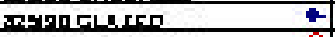 & 준 & armp & $27 \times 10$ \\
\hline 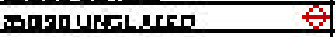 & $12<1 \mathrm{r}$ & anto & $27<4$ \\
\hline magncuren & 19,21 & 프.253 & 22,020 \\
\hline arspDURFLerse & 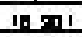 & 13220 & $12 \mathrm{rzr}$ \\
\hline arsporarso & $15 \times 3$ & 13242 & 1242 \\
\hline
\end{tabular}

arvpoch

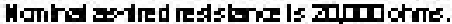

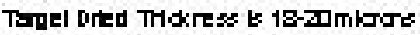

Emple fred Inc EA 1 (T

Figure F-1 


\section{FIRING PROFILE SENSITIVITY}

DUPONT 2041(10K OHMS PER SQUARE)

Percent fr om Nominal Values - P rinted on Alumina

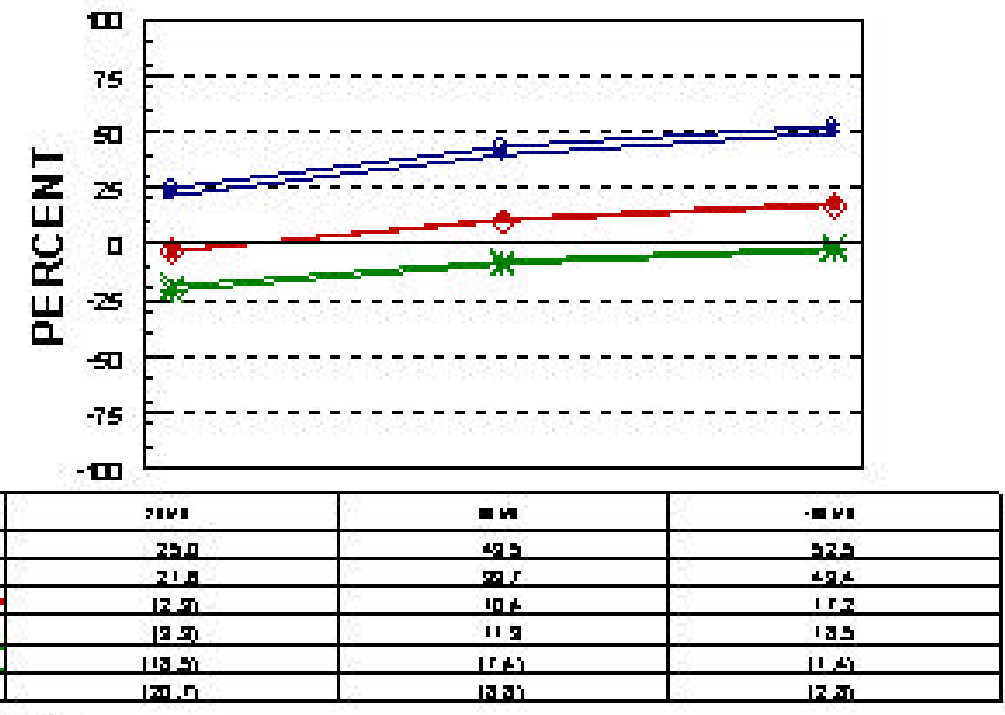

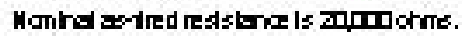

Taplel orted Thdoress b 18-70milars

Empes fird InC E* 1 (T

\section{FURNACE SENSITIVITY}

DUPONT 2041(10K OHMS PER SQUARE)

Actual Values - Printed on Alumina

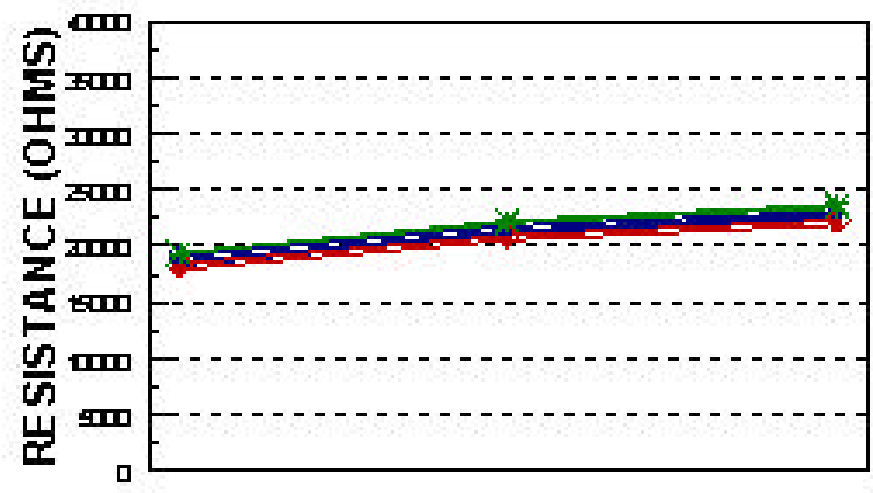

\begin{tabular}{|c|c|c|c|}
\hline RESISTORGEOMETRY & $\boldsymbol{x}$ & Inve & -auna \\
\hline 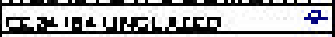 & $19 \mathrm{~ms}$ & $21 \mathrm{rg}$ & $271 \mathrm{~m}$ \\
\hline 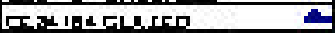 & $13<1$ & 21204 & 27.00 \\
\hline 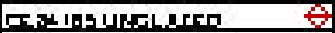 & $13<7$ & song & 7272 \\
\hline 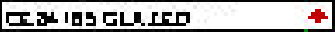 & irgan & 正394 & 2130 \\
\hline 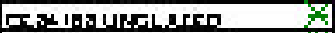 & $12<18$ & ang & $22<2$ \\
\hline 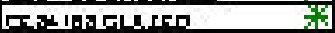 & $12 \% 1$ & 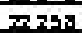 & $290 \%$ \\
\hline
\end{tabular}

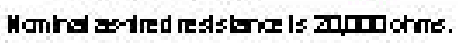

Tantel bited THdkress b 18-7lmilars

somple fred whagroprote

Figure F-3 


\section{FURNACE SENSITIVITY}

\section{DUPONT 2041(10K OHMS PER SQUARE)}

Percent fr om Nominal Values - P rinted on Alumina

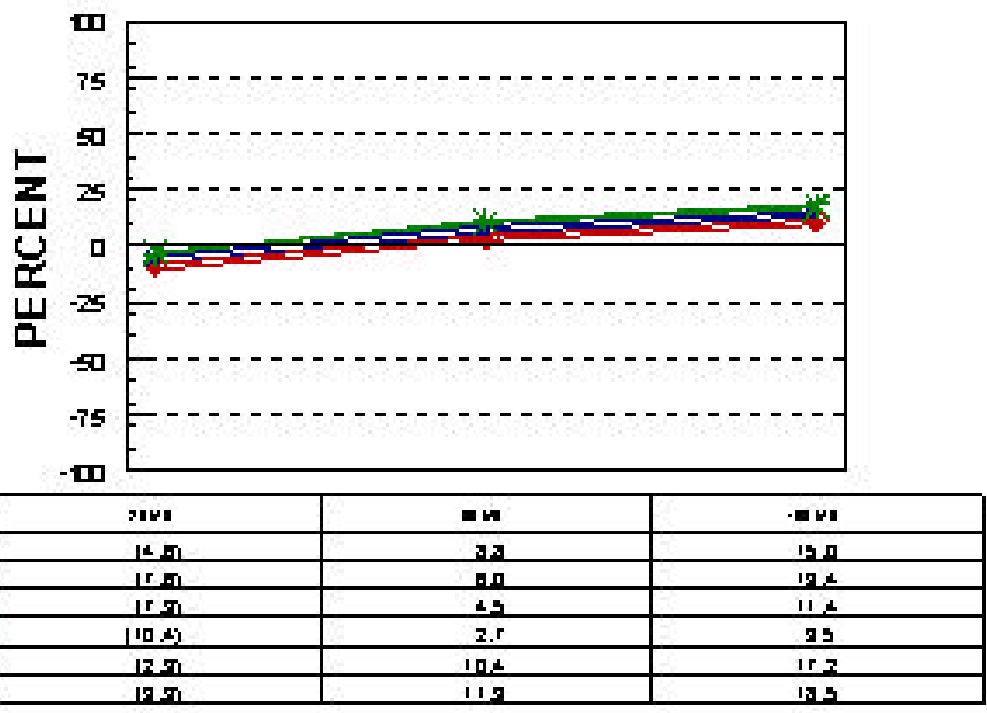

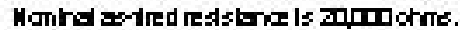

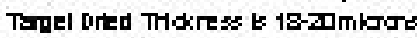

Eample fied withangerole

\section{NORMALIZED SHEET RESISTANCE DUPONT 2041(10K OHAS PER SQUARE) \\ Actual Values - Printed on Alumina}

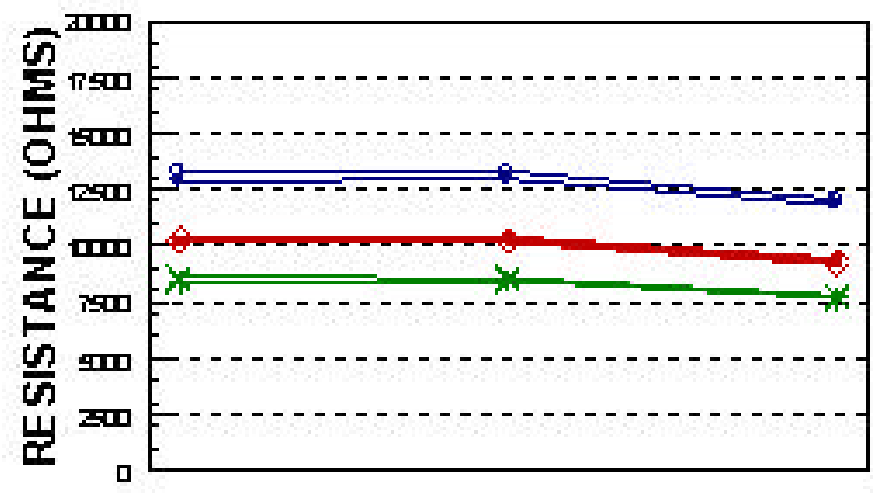

\begin{tabular}{|c|c|c|c|}
\hline RESISTOR GEOMETRY & $\boldsymbol{x} \boldsymbol{n}$ & nuvi & - anva \\
\hline 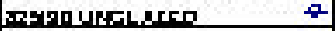 & $19=2$ & 19218 & 12018 \\
\hline 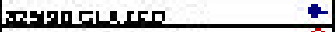 & $12 \mathrm{mi}$ & 129:2 & $113 \mathrm{x}$ \\
\hline 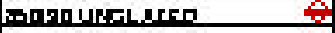 & 102 & 10247 & $27 \pi$ \\
\hline magacherp & 10. & I0.28 r & 2031 \\
\hline arspoukfingra & s.2. & 320 & $\mathrm{ram}$ \\
\hline arspoch & 3412 & $34 m$ & $\mathrm{rm}$ \\
\hline
\end{tabular}

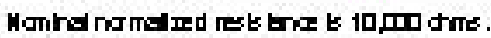

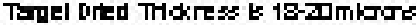

Emples fred InC ER+1

Figure F-5 


\section{NORMALIZED SHEET RESISTANCE}

\section{DUPONT 2041(10K OHMS PER SQUARE)}

Percent from Nomin al Normalized Resistance - Printed on Alumina

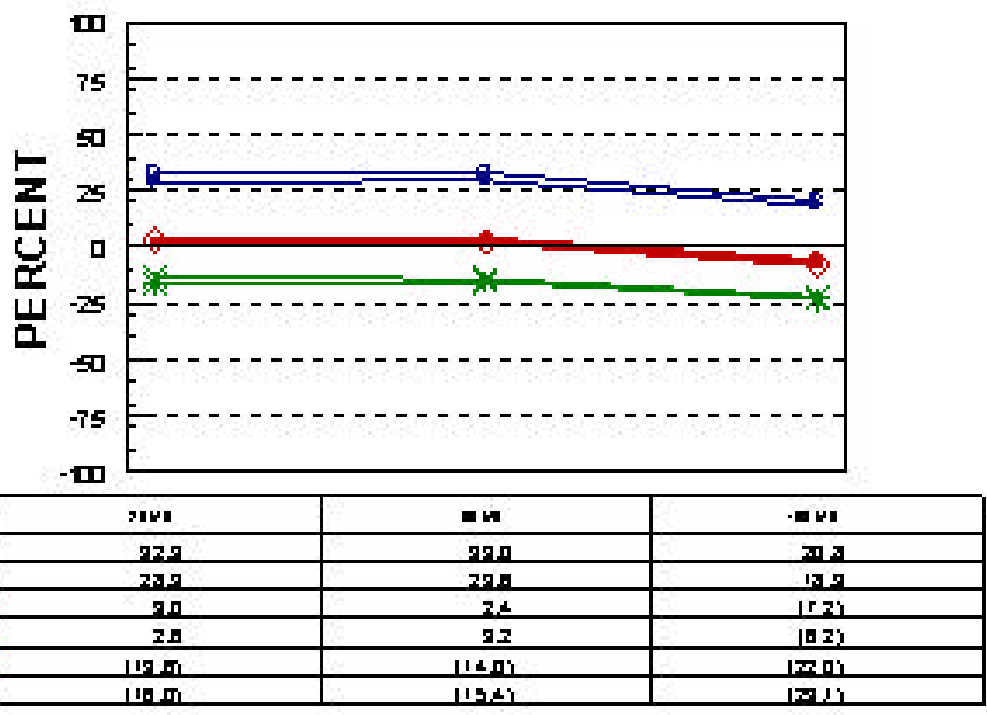

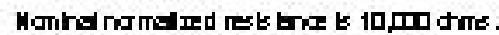

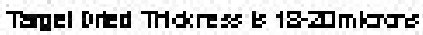

Empes fird InC E\& 1 I

\section{NORMALIZED SHEET RESISTANCE DUPONT 2041(10K OHMS PER SQUARE) \\ Actual Values - Printed on Alumina}

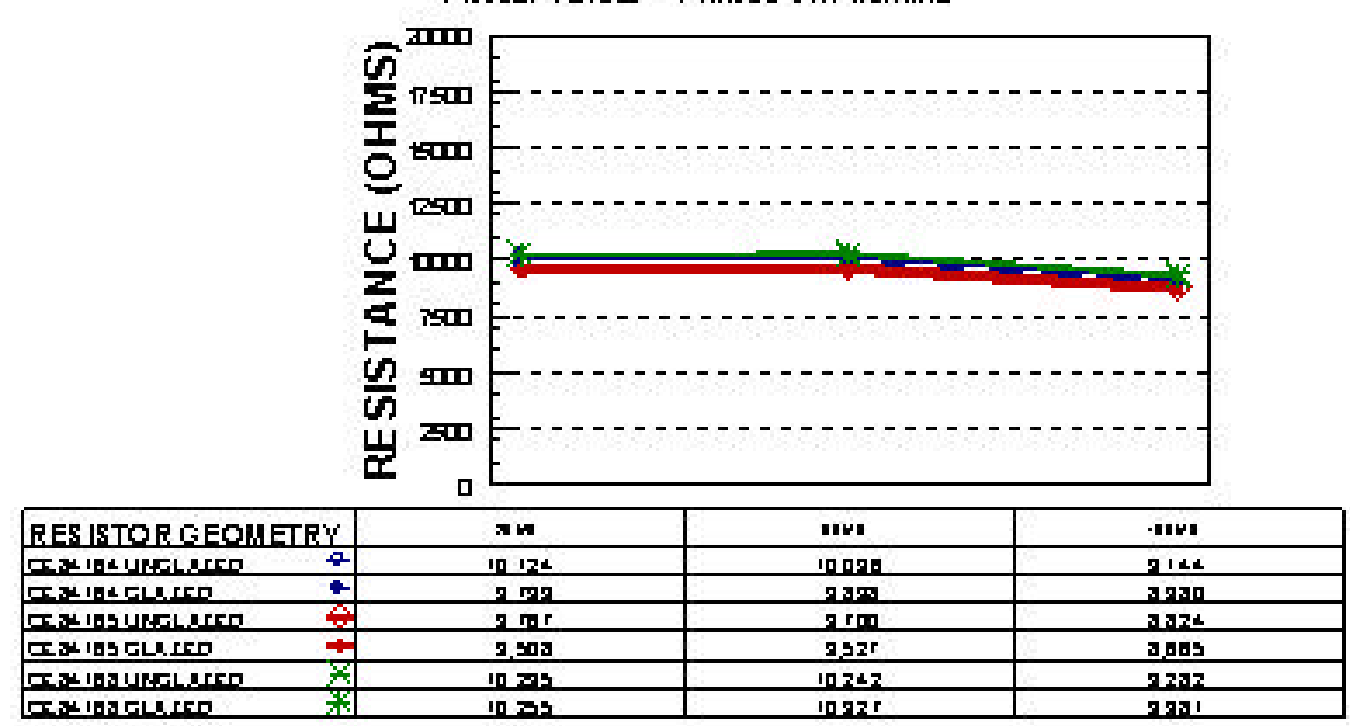

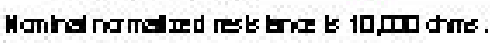

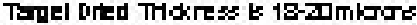

somples fied whagroprote 


\section{NORMALIZED SHEET RESISTANCE}

\section{DUPONT 2041(10K OHMS PER SQUARE)}

Percent from Nomin al Normalized Resistance - Printed on Alumina

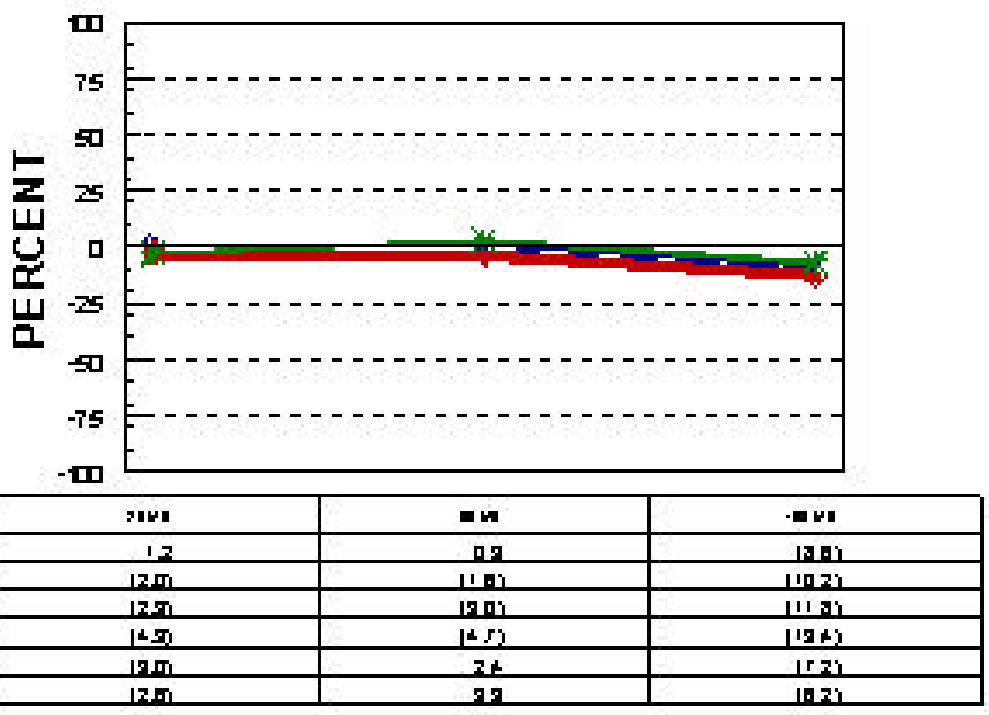

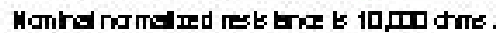

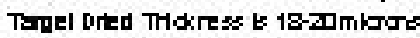

Emples fred InCEAt 1 (T

\section{THICKNESS \& RESISITIVITY COMPARISON DUPONT 2041(10K OHMS PER SQUARE)}

Actual Values - Printed on Alumina

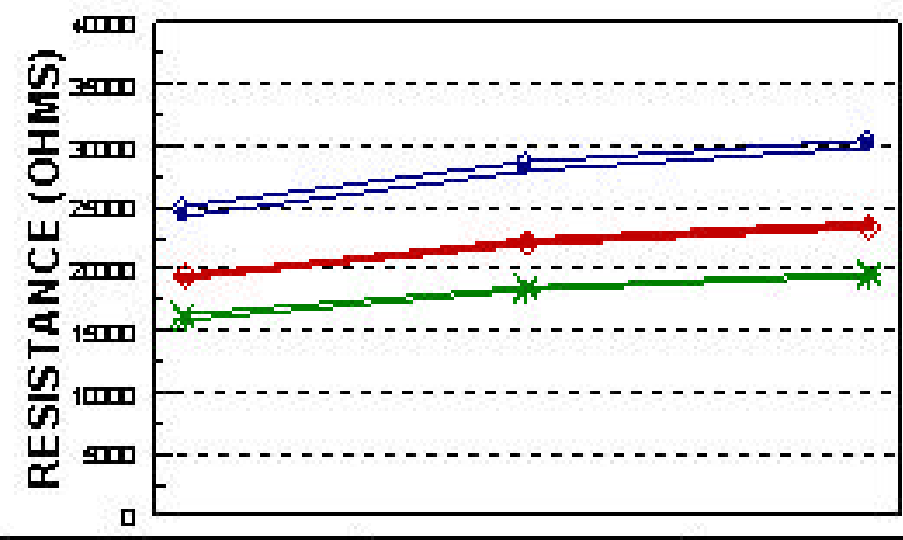

\begin{tabular}{|c|c|c|c|}
\hline DRIFD THICKNESS & D Herew & abrad & IfHexed \\
\hline ESTI U MOLAZEO & 25 Dis & ZRTW & 고옹 \\
\hline MSODGLAZED & $2+30$ & $2750 x$ & İs1 \\
\hline BSTR UMOLAZED & 19,45 & z2m5 & $7,4+9$ \\
\hline ERTMOOLAZEO & $197+1$ & 2725 & 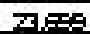 \\
\hline BSTOUMOLAZEO & 1697 & $185 \times$ & $9.7 \pi$ \\
\hline BSTD QLAZEO & $153 x$ & 1872 & 9,434 \\
\hline
\end{tabular}




\section{THICKNESS \& RESISITIVITY COMPARISON}

\section{DUPONT 2041(10K OHMS PER SQUARE)}

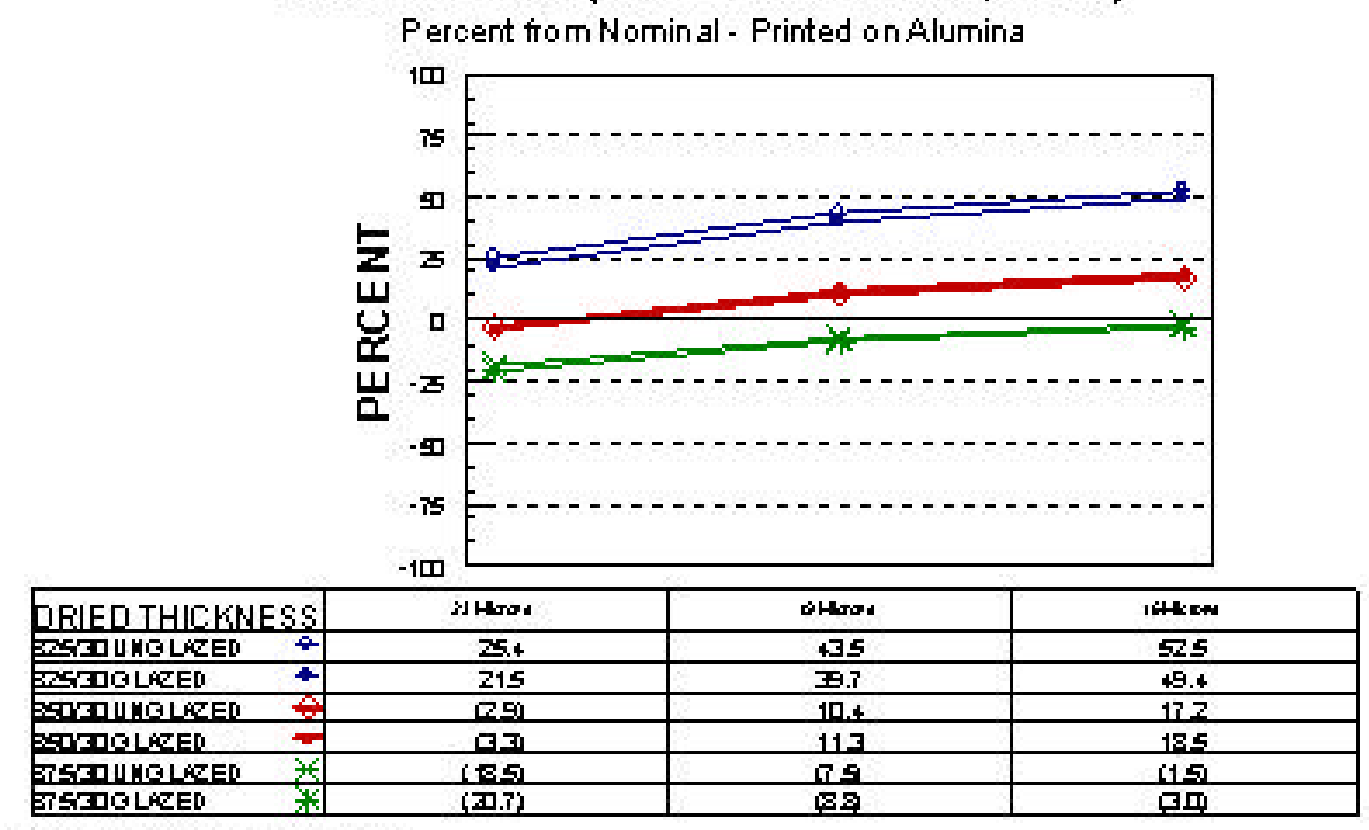

\section{THICKNESS RELATIONSHIP}

\section{DUPONT 2041(10K OHAS PER SQUARE)}

Printed on Alumina

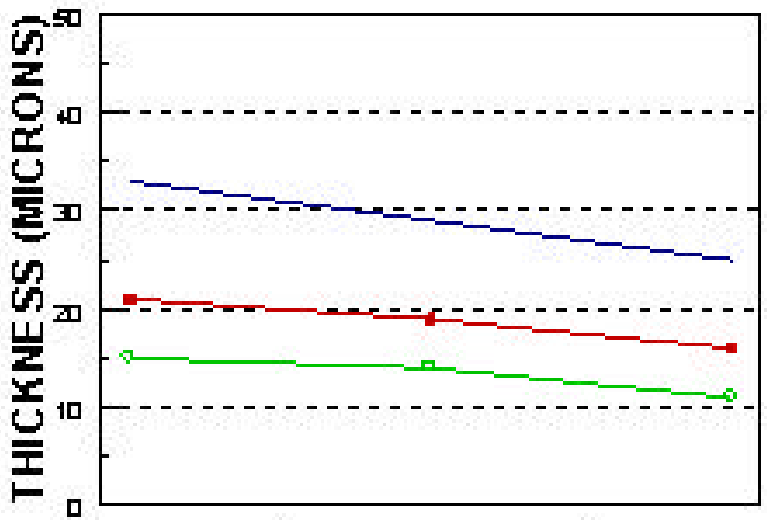

\begin{tabular}{|c|c|c|c|}
\hline GEOMETRY & 25 MIL & so ML & 1m ML \\
\hline MET THICKNESS & 33 & 29 & 25 \\
\hline DEIFD THICKNESS & 21 & 19 & 16 \\
\hline EIRED THICKNESS & 15 & 14 & 11 \\
\hline
\end{tabular}

Tagel orted Thdores b 18-0]miars

Figure F-11 
APPENDIX G

DU PONT 2051 RESISTOR PRINTING DATA

(100K Ohm)

\section{FIRING PROFILE SENSITIVITY DUPONT 2051(100K OHHS PER SQUARE)}

Actual Values - Printed on Alumina

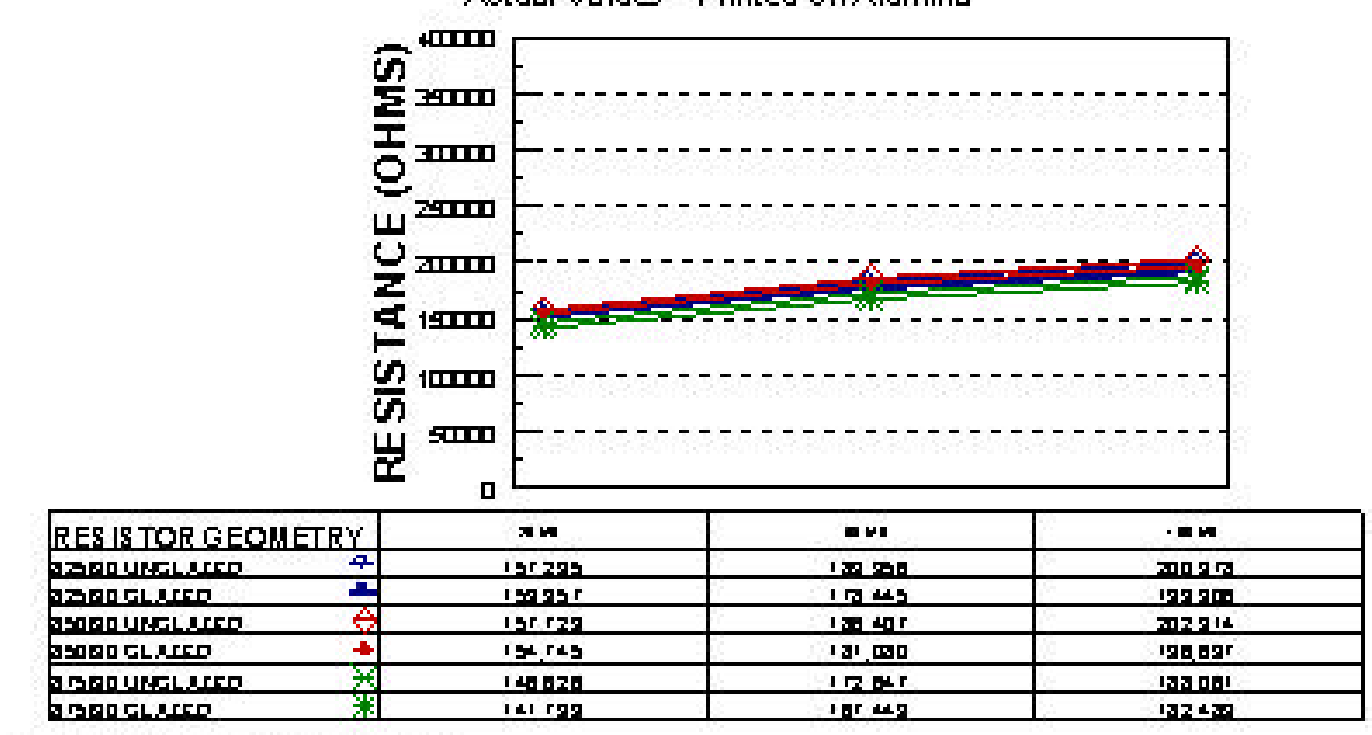

Manind ayred retstanc is andm orms.

Tantel orted THdkress b 18-70milars

Emples fred InCE\& 19

Figure G-1 


\section{FIRING PROFILE SENSITIVITY}

DUPONT 2051(100K OHMS PER SQUARE)

Percent fr om Nominal Values - P rinted on Alumina

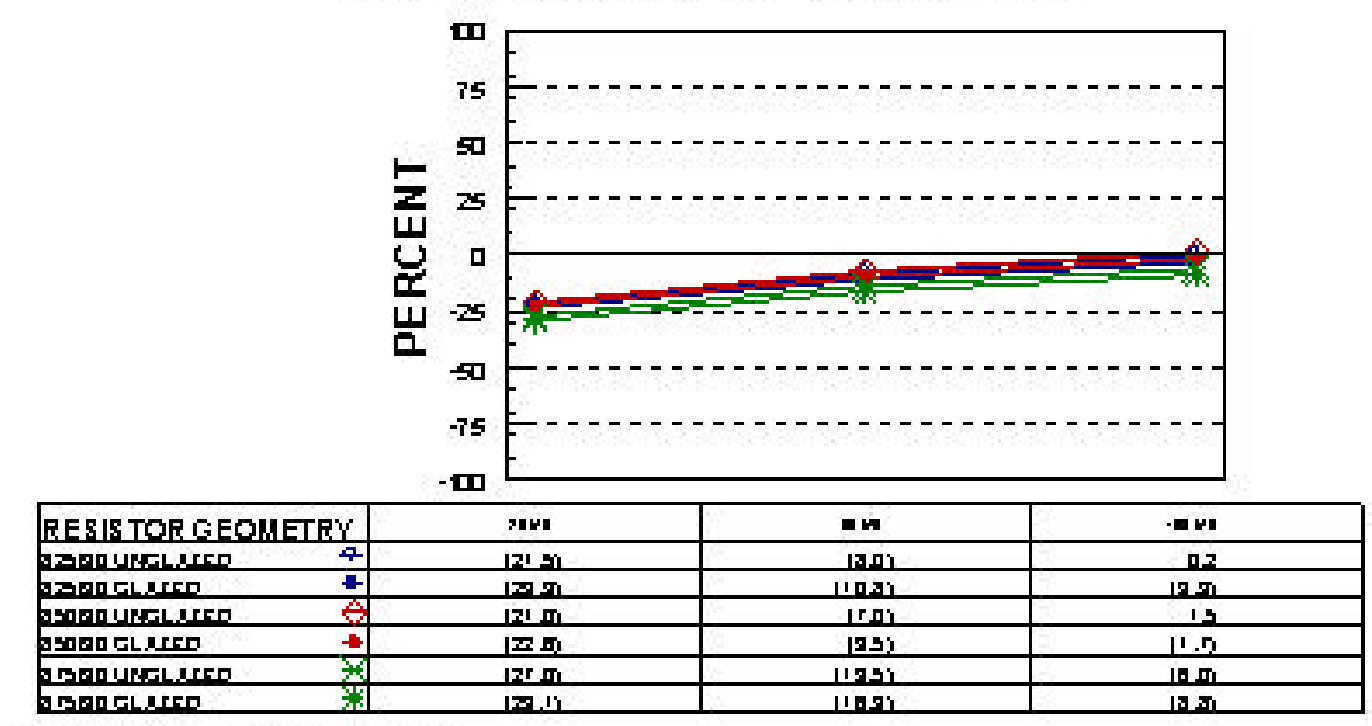

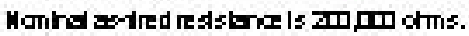

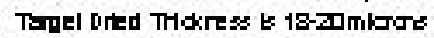

Empes fred InC ER+1

FURNACE SENSITIVITY DUPONT 2051(100K OHHS PER SQUARE)

Actual Values - Printed on Alumina

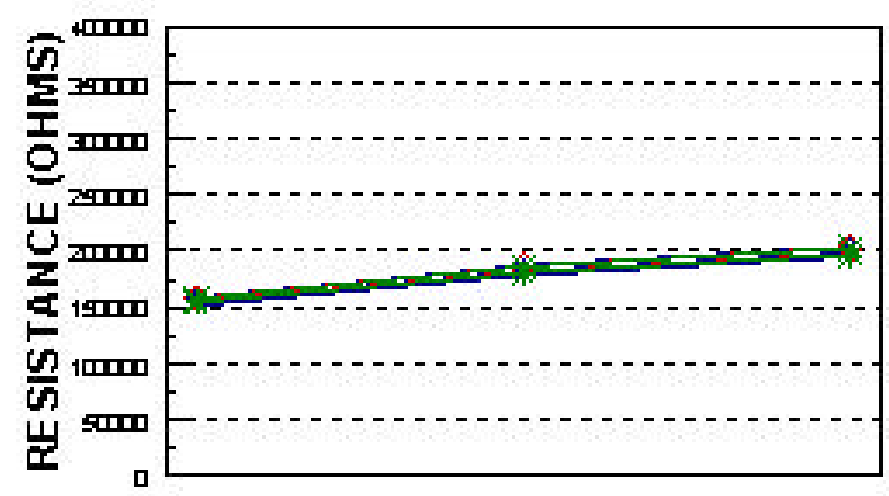

\begin{tabular}{|c|c|c|c|}
\hline RESISTOR GEOMETRY & $\boldsymbol{x}$ & avi & $\cdot \mathbf{m} \mathbf{m}$ \\
\hline 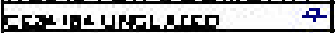 & $1 \times 9798$ & $\operatorname{ls} \pi \mathrm{s}$ & mpax \\
\hline 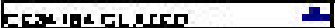 & 1901 & $\ln 20$ & 19. rer \\
\hline 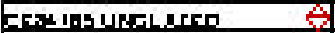 & 1,09202 & $1.0 \mathrm{gax}$ & singe \\
\hline 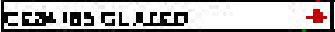 & פטgקו & 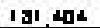 & $\lg r .25$ \\
\hline 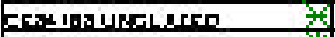 & $13 \mathrm{r} 27$ & $1300 \mathrm{r}$ & .172014 \\
\hline 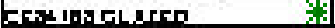 & $1 \% \mathrm{r} \approx \mathrm{s}$ & $13 \mathrm{~m}$ & 19.0.0 \\
\hline
\end{tabular}

Monind avired retstrax is andm orms.

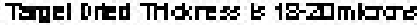

smpes fied wi hagroprote

Figure G-3 


\section{FURNACE SENSITIVITY}

\section{DUPONT 2051(100K OHAS PER SQUARE)}

Percent fr om Nominal Values - P rinted on Alumina

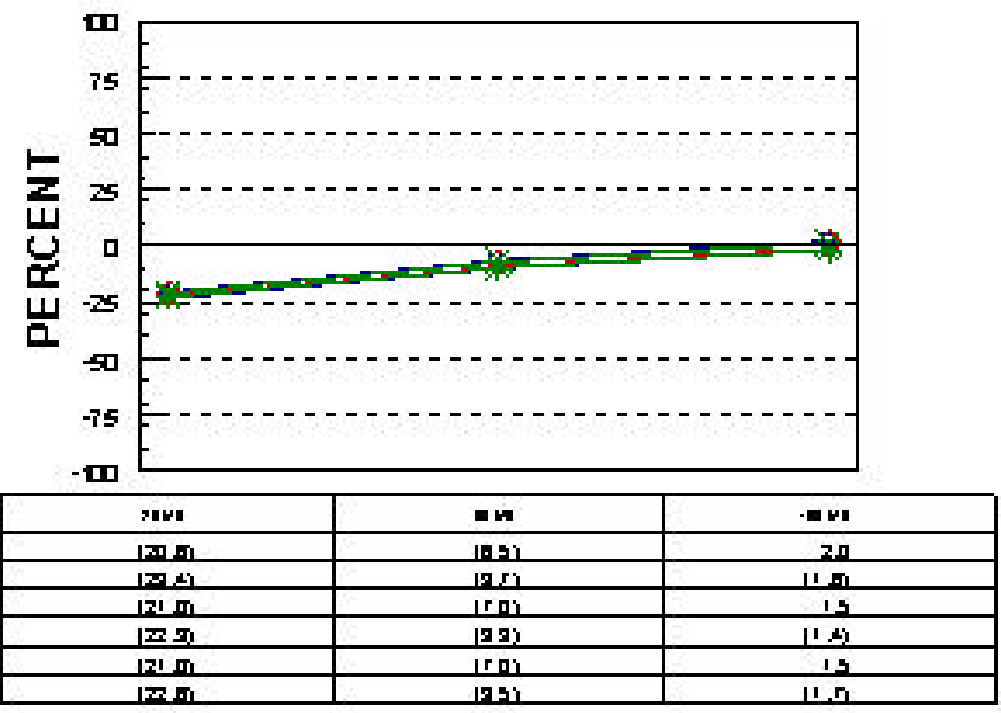

Momind ayred retstorc is

Tapel orted Thdoress b 18-20miags

Emple fred wihagroprote

\section{NORMALIZED SHEET RESISTANCE DUPONT 2051(100K OHMS PER SQUARE) \\ Actual Values - Printed on Alumina}

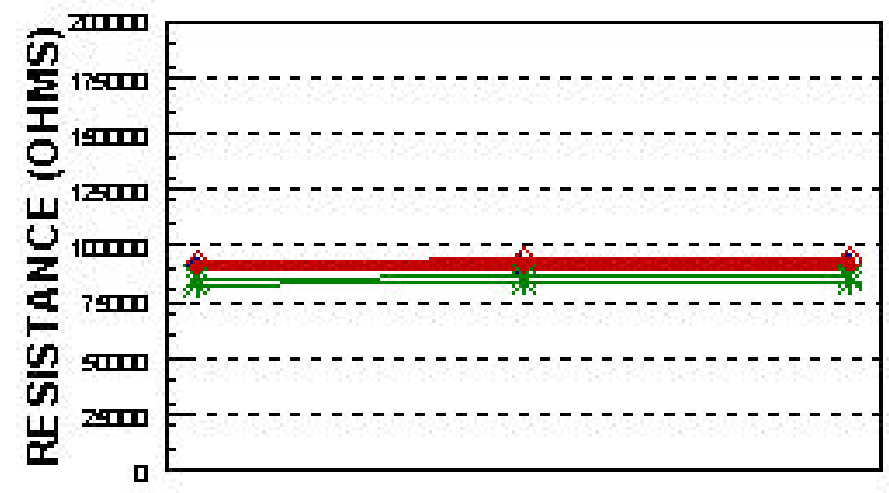

\begin{tabular}{|c|c|c|c|}
\hline RESISTOR GEOMETRY & $\boldsymbol{x}$ & avi & $\cdot \mathbf{m} \mathbf{m}$ \\
\hline 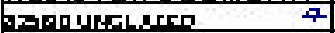 & 210 & 9210 & or.214 \\
\hline songhers & 0.92 & $30 \times m$ & 325 \\
\hline 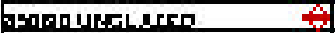 & goro & ตnตr & mal \\
\hline 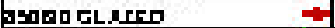 & m2 & gn $r$ ㅉ․ & mos \\
\hline 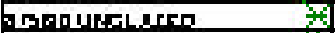 & $\sin 2$ & stom & ה.8. \\
\hline SpDocherse & $\mathrm{senr}$ & and & 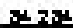 \\
\hline
\end{tabular}

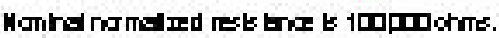

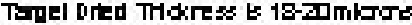

Emples fred inc Est19

Figure G-5 


\section{NORMALIZED SHEET RESISTANCE \\ DUPONT 2051(100K OHMS PER SQUARE)}

Percent from Nominal - Printed on Alumina

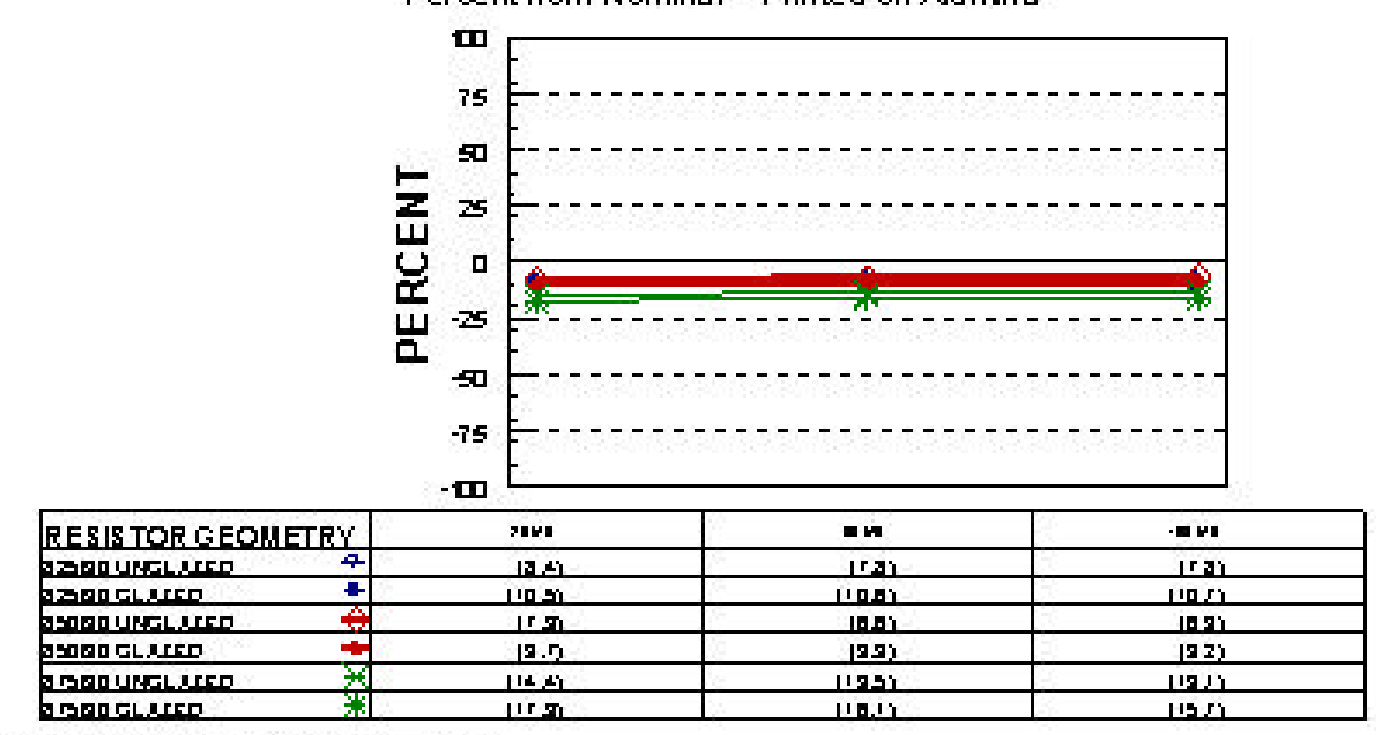

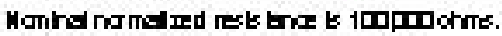

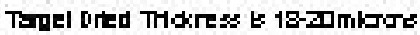

Emples fred IncEste

\section{NORMALIZED SHEET RESISTANCE DUPONT 2051(100K OHMS PER SQUARE) \\ Actual Values - Printed on Alumina}

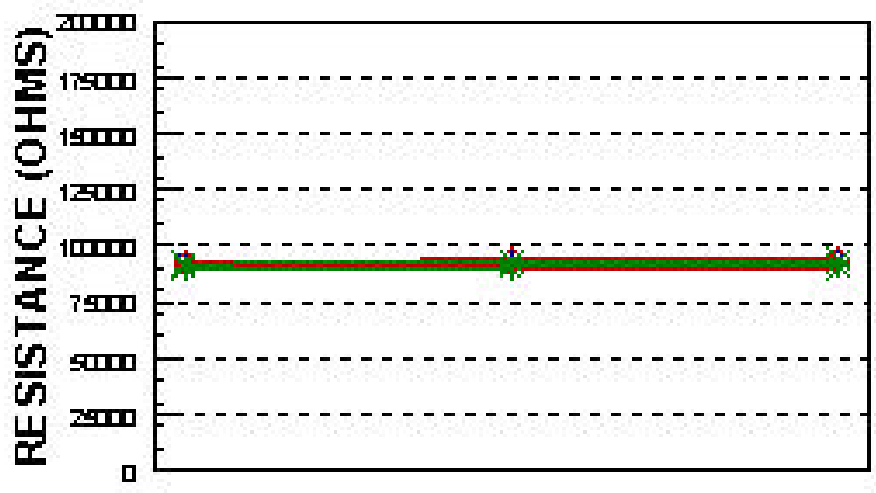

\begin{tabular}{|c|c|c|c|}
\hline RES IS TOR GEOMEIRY & $\boldsymbol{x}$ & avi & $\cdot=n$ \\
\hline 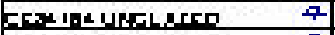 & $g=0$. & $97 \mathrm{rm}$ & $2 \pi n$ \\
\hline 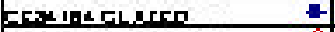 & mar & 904:9 & $m x$ \\
\hline 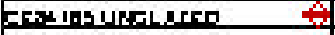 & mang & ตn? & mane \\
\hline 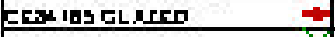 & m.w & פas & שים \\
\hline 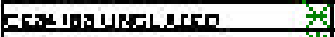 & grorn & ต้ตั & nral \\
\hline 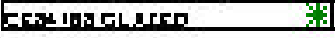 & $\operatorname{mgn} 2$ & g & nx \\
\hline
\end{tabular}

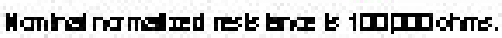

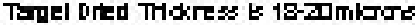

somples fird wi hagraprote 


\section{NORMALIZED SHEET RESISTANCE}

DUPONT 2051(100K OHMS PER SQUARE)

Percent from Normalized Nomin al - Printed on Alumina

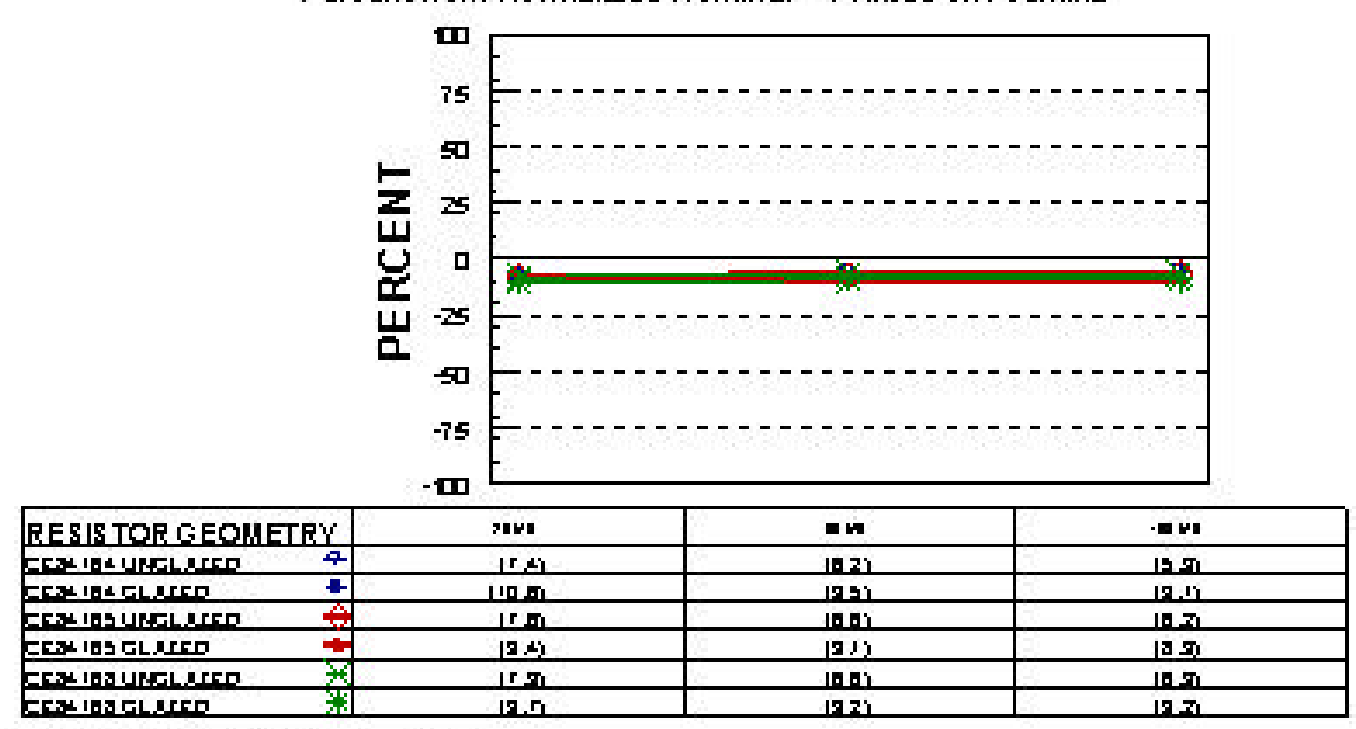

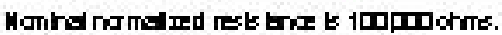

Tamel orted THdkress b 18-Zlmikros

Emple fred whaspoprote

\section{THICKNESS \& RESISITIVITY COMPARISON DUPONT 2051(100K OHMS PER SQUARE)}

Actual Values - Printed on Alumina

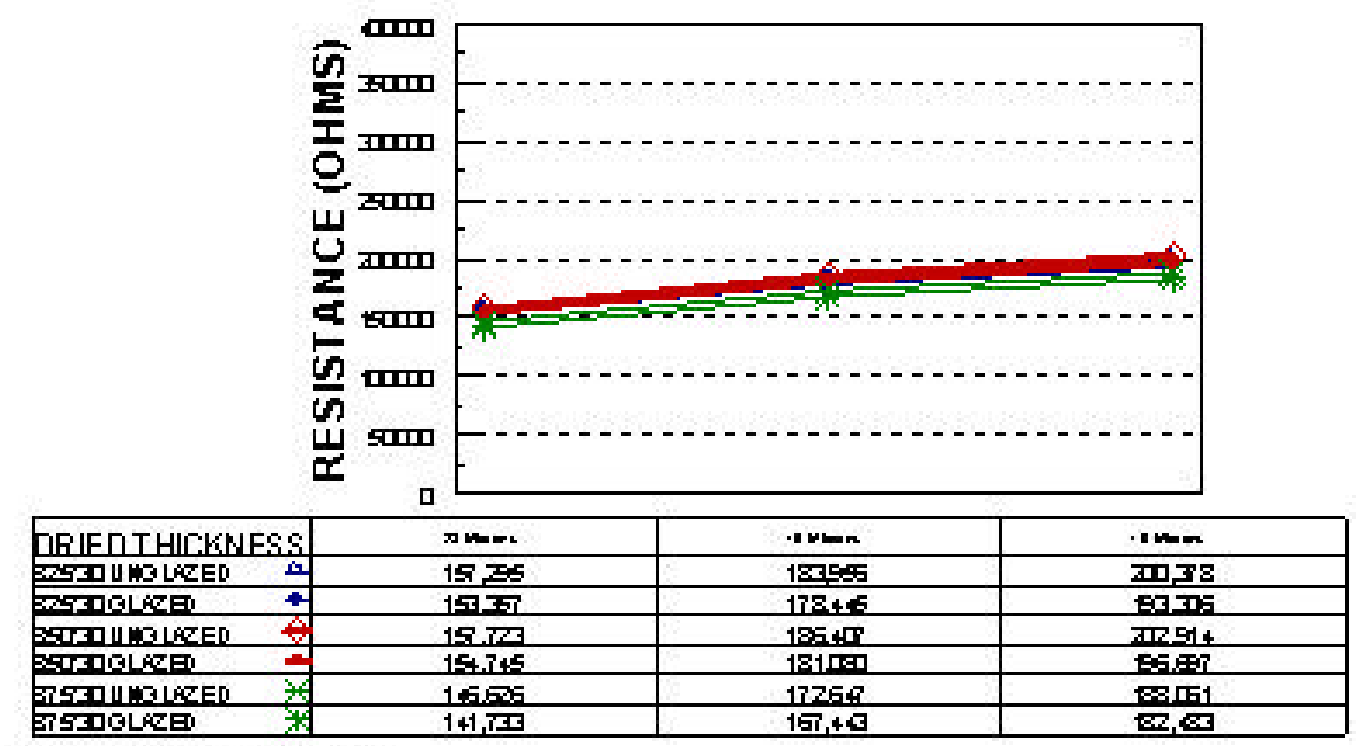

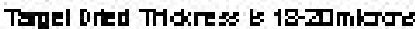

Emples fred InC EA 19

Figure G-9 


\section{THICKNESS \& RESISITIVITY COMPARISON}

\section{DUPONT 2051(100K OHMS PER SQUARE)}

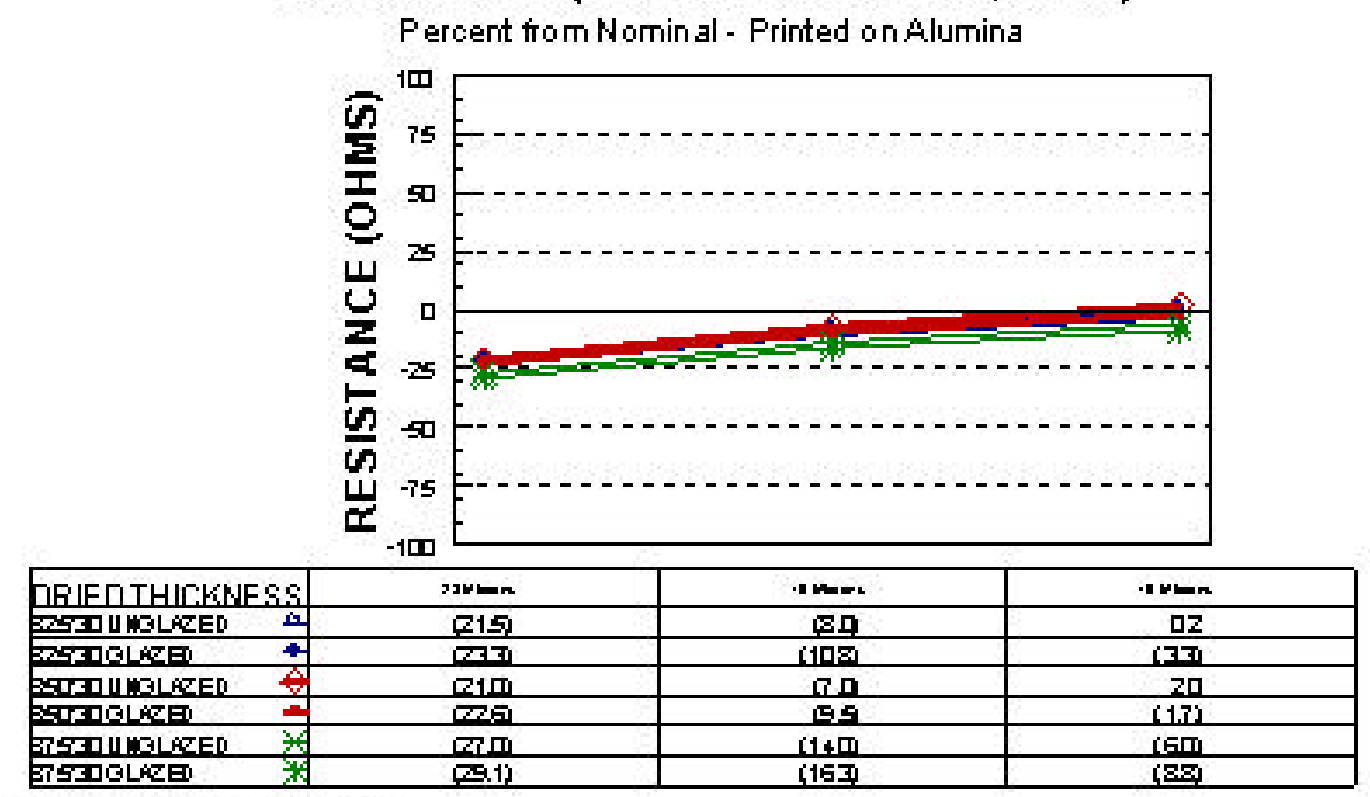

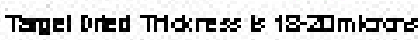

Emples fred inc Est 1 (T

\section{THICKNESS RELATIONSHIP \\ DUPONT 2051(100K OHMS PER SQUARE)}

Printed on Alumina

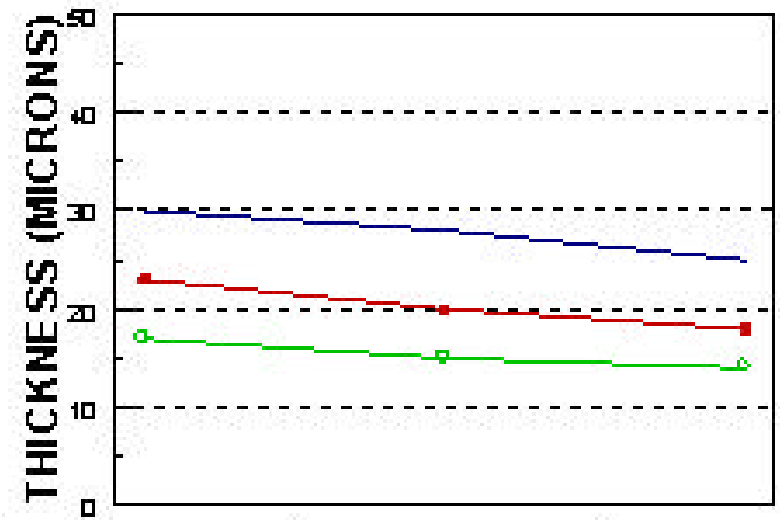

\begin{tabular}{|c|c|c|c|}
\hline GEOMETRY & 25 MIL & s MIL & 1m MIL \\
\hline MET THICKNESS & 30 & 28 & 25 \\
\hline DRIFD THICKNESS - & 23 & 20 & 18 \\
\hline EIRED THICKNESS & 17 & 15 & 14 \\
\hline
\end{tabular}

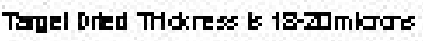

Figure G-11 
APPENDIX H

DU PONT 2061 RESISTOR PRINTING DATA

(1 Meg Ohm)

\section{FIRING PROFILE SENSITIVITY}

DUPONT 2061(1MEG OHM PER SQUARE)

Actual Values - Printed on Alumina

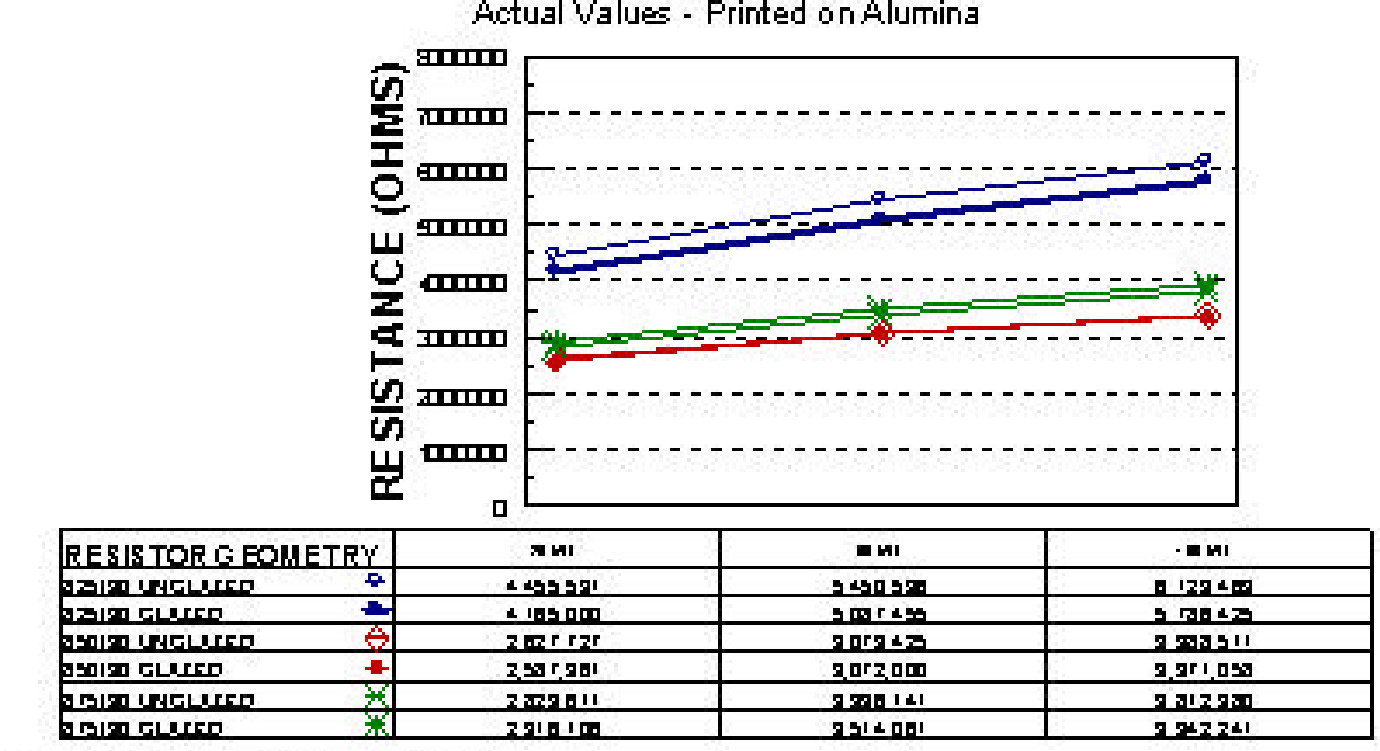

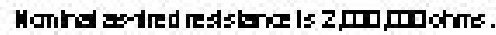

Tagel orted THdkress is 18-70miars

Emples fred Inc E*19

Figure $\mathrm{H}-1$ 


\section{FIRING PROFILE SENSITIVITY}

\section{DUPONT 2061(1MEG OHM PER SQUARE)}

Percent from Nomin al Values - Printed on Alumina

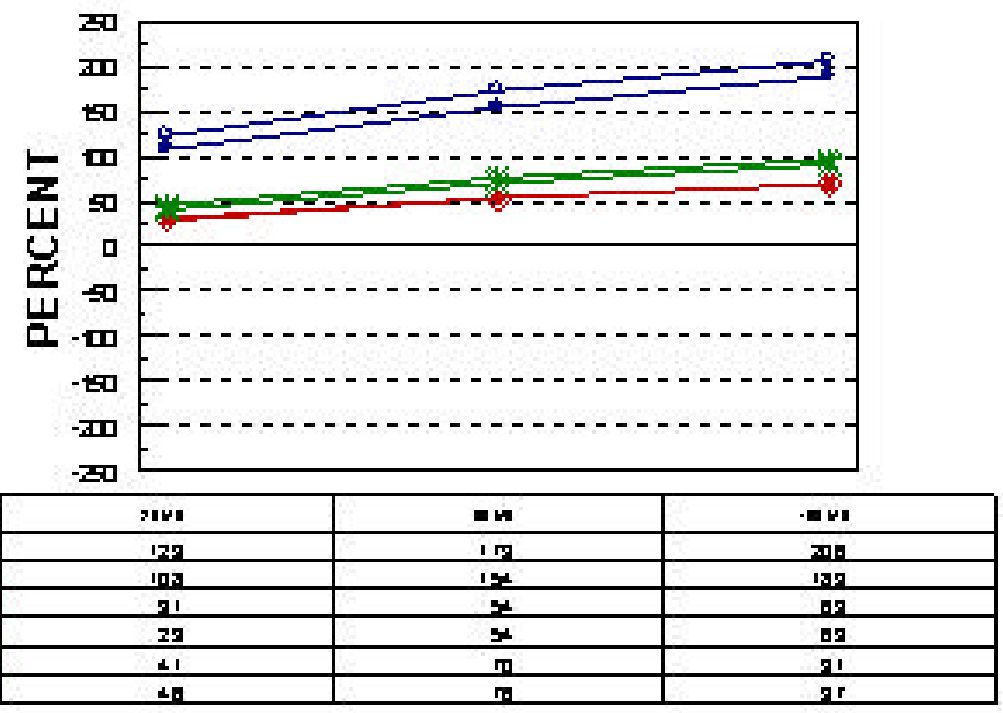

Momind ay-1red reststorc is 2 m m mor

Emples fred Inc Eat 1 (

\section{FURNACE SENSITIVTYY}

\section{DUPONT 2061(1MEG OHM PER SQUARE)}

Actual Values - Printed on Alumina

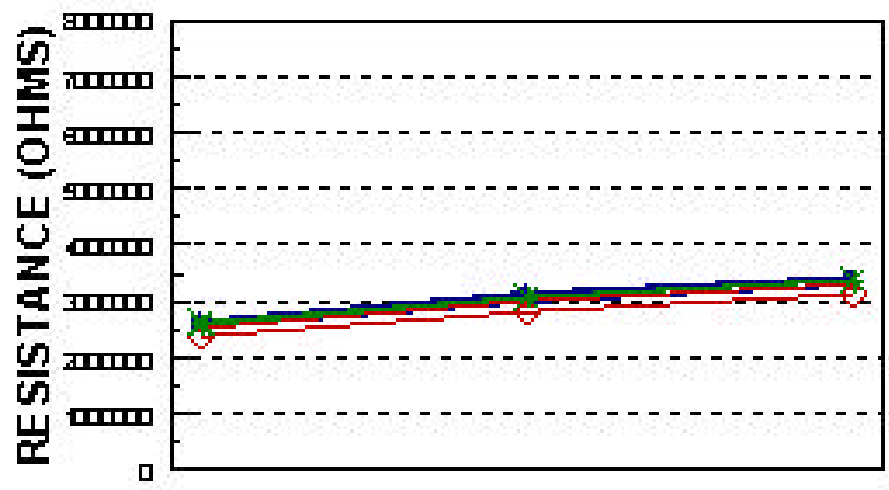

\begin{tabular}{|c|c|c|c|}
\hline RESISTORG EOMETRY & n mı & = мı & - \\
\hline 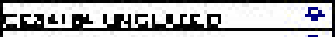 & aprapr & $2 \log n=$ & $2=0211$ \\
\hline 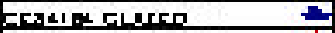 & 2 monar & 21730.r & 240.25 \\
\hline 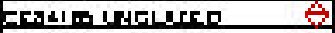 & 2002345 & $2 x+30 m$ & 217210 \\
\hline 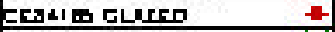 & 2.01.0见 & 2011,2 & 201 \\
\hline 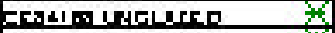 & anr rar & gorg & gखvali \\
\hline
\end{tabular}

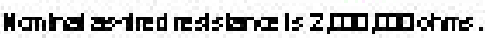

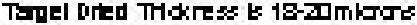

amples fred wi hagugnote

Figure $\mathrm{H}-3$ 


\section{FURNACE SENSITIVITY}

\section{DUPONT 2061(1MEG OHM PER SQUARE)}

Percent fr om Nominal Values - Printed on Alumina

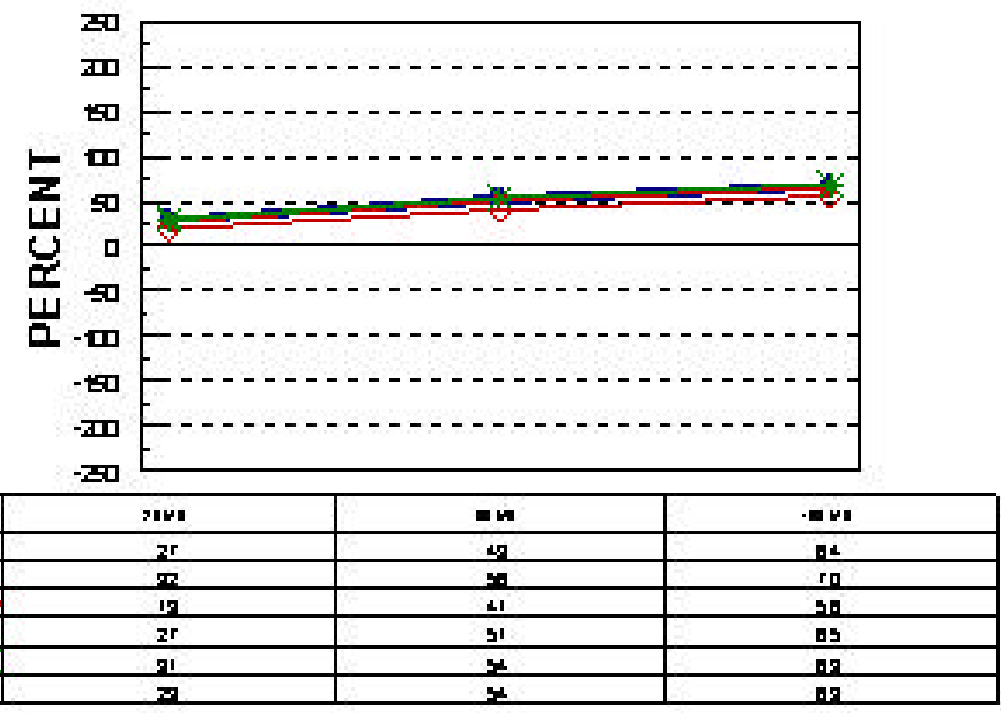

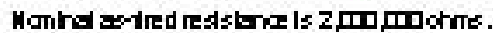

Tarpel orted Thdoress b 18-rimilars

Emples fred wi haguponote

\section{NORMALIZED SHEET RESISTANCE \\ DUPONT 2061(1MEG OHM PER SQUARE)}

Actual Values - Printed on Alumina

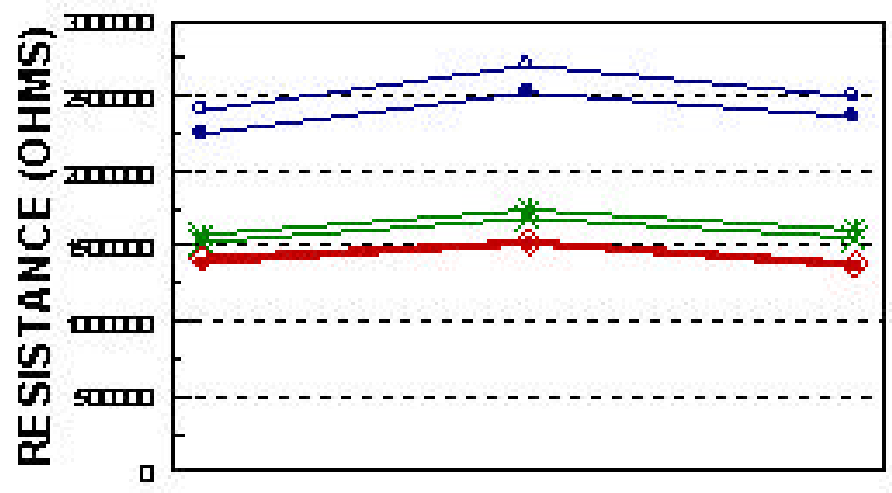

\begin{tabular}{|c|c|c|c|}
\hline RESISTOR G EOMETRY & a mi & = иı & · mi \\
\hline 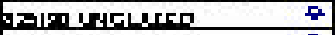 & $2 \angle 05021$ & $2 \mathrm{man}$ & $240.5 m$ \\
\hline 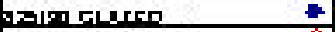 & $273 \times 27 R$ & 25n:m & 2919 \\
\hline 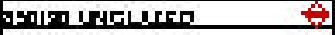 & 141307 & $12 n<34 r$ & $10013 x$ \\
\hline 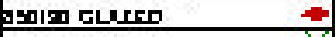 & 1.201.29 & 1,2028040 & $1,2 r<40$ \\
\hline 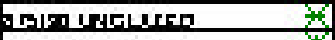 & $12021 \pi 2$ & 1.04025 & $12025 m$ \\
\hline 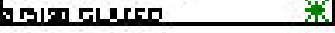 & $13 r<0 m$ & $1 \mathrm{mg} 1 \mathrm{~m}$ & 1.0173 \\
\hline
\end{tabular}

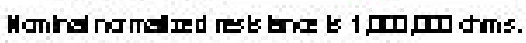

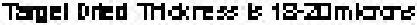

Emples fred InC ER1 1 (

Figure $\mathrm{H}-5$ 


\section{NORMALIZED SHEET RESISTANCE}

DUPONT 2061(1MEG OHM PER SQUARE)

Percent from Nominal - Printed on Alumina

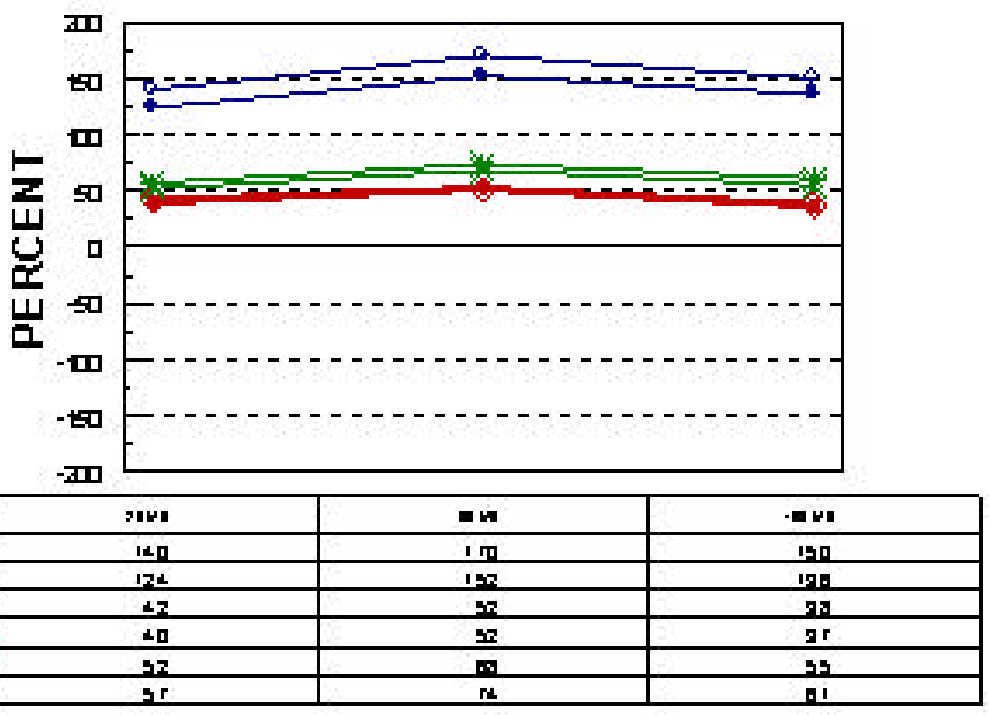

\begin{tabular}{|c|c|c|c|}
\hline RESISTOR GEOMEIRY & Pavi & $=\mathbf{n}$ & evi \\
\hline 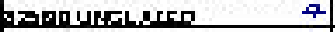 & 140 & $1 m$ & סקו \\
\hline ganglarsp & 174 & 192 & 19: \\
\hline 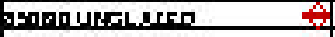 & 42 & 32 & 9x \\
\hline 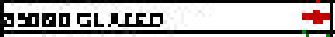 & $\Delta 0$ & 22 & gr \\
\hline 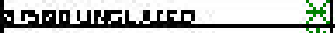 & 32 & m & 35 \\
\hline 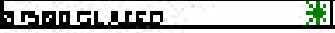 & sr & $m$ & 1 \\
\hline
\end{tabular}

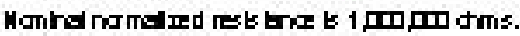

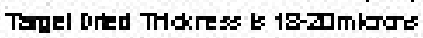

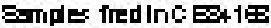

\section{NORMALIZED SHEET RESISTANCE \\ DUPONT 2061(1MEG OHM PER SQUARE)}

Actual Values - Printed on Alumina

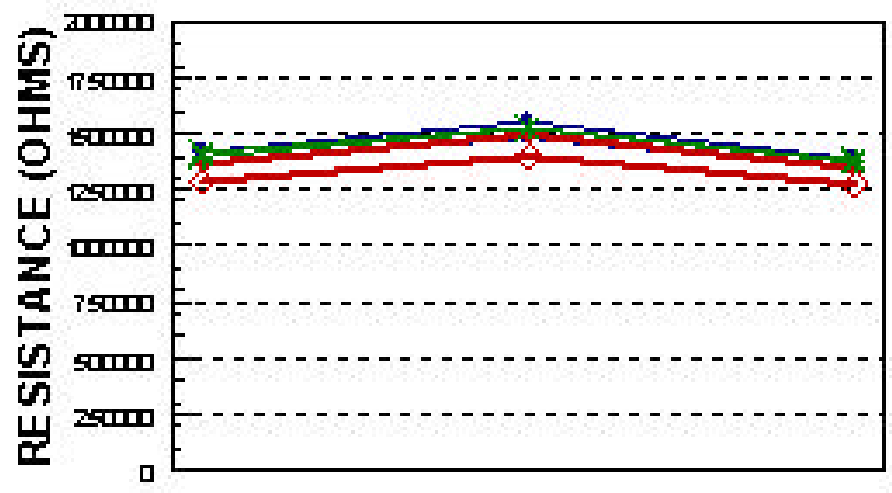

\begin{tabular}{|c|c|c|c|}
\hline RESISTOR G EOMETRY & Nou & = мı & • m mı \\
\hline 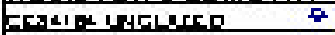 & $10.2 \mathrm{r} \Delta 1$ & 158213 & $12 \times 1<4$ \\
\hline 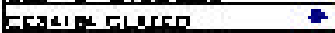 & $1<71<10$ & 10192 & $1 \mathrm{man}$ \\
\hline 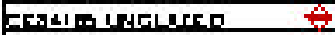 & $1 \times 1020$ & $100 \mathrm{ng}$ & izrserm \\
\hline 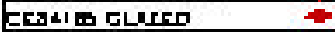 & 1 gas & $1.40 \mathrm{rg}$ & $102 \times 112$ \\
\hline 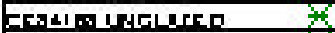 & 141347 & $102454 r$ & $1015 \pi$ \\
\hline 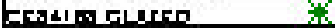 & 1 व.9p & 1,200340 & $12 \mathrm{ram}$ \\
\hline
\end{tabular}

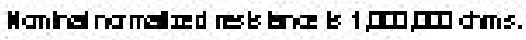

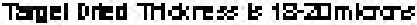

amples fred wi hagroprote

Figure $\mathrm{H}-7$ 


\section{NORMALIZED SHEET RESISTANCE}

DUPONT 2061(1MEG OHM PER SQUARE)

Percent from Normalized Nominal - Printed on Alumina

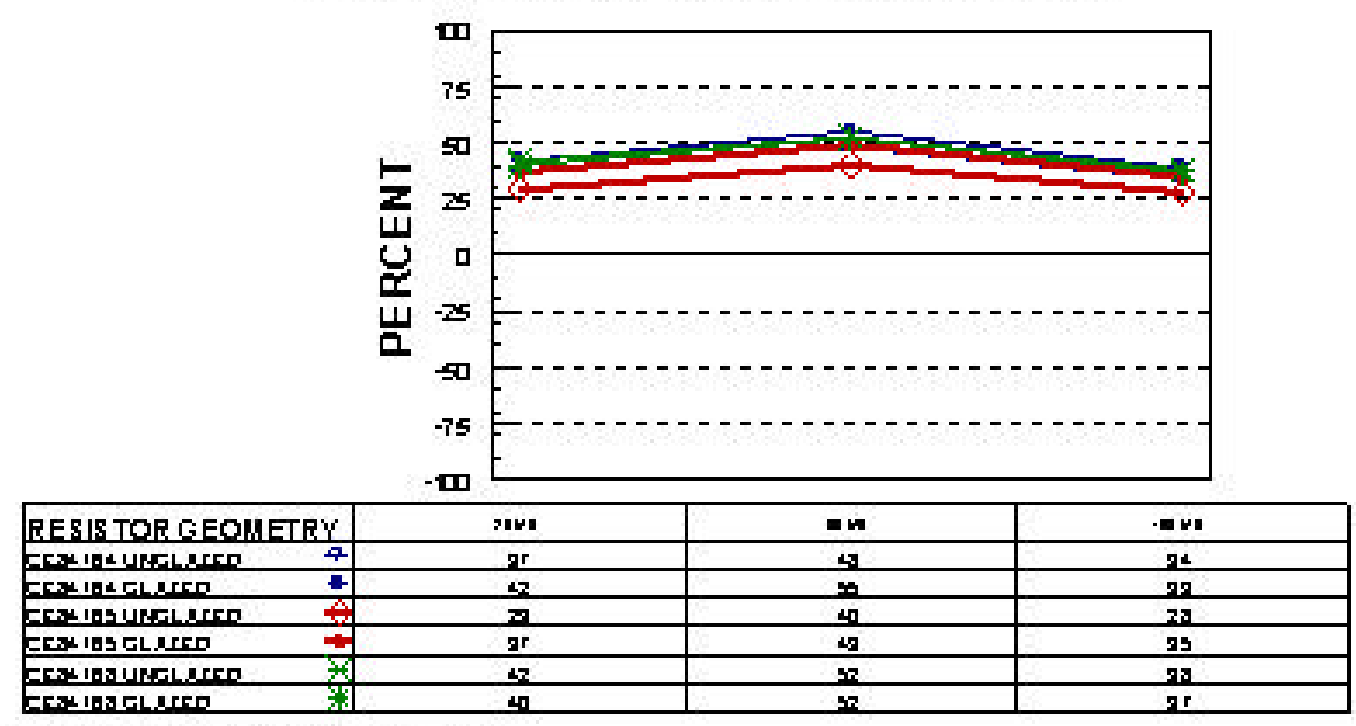

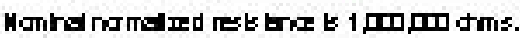

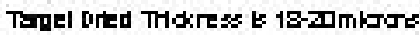

Emple fred wi hagroprote

\section{THICKNESS \& RESISITIVITY COMPARISON}

DUPONT 2061(1MEG OHM PER SQUARE)

Actual Values - Printed on Alumina

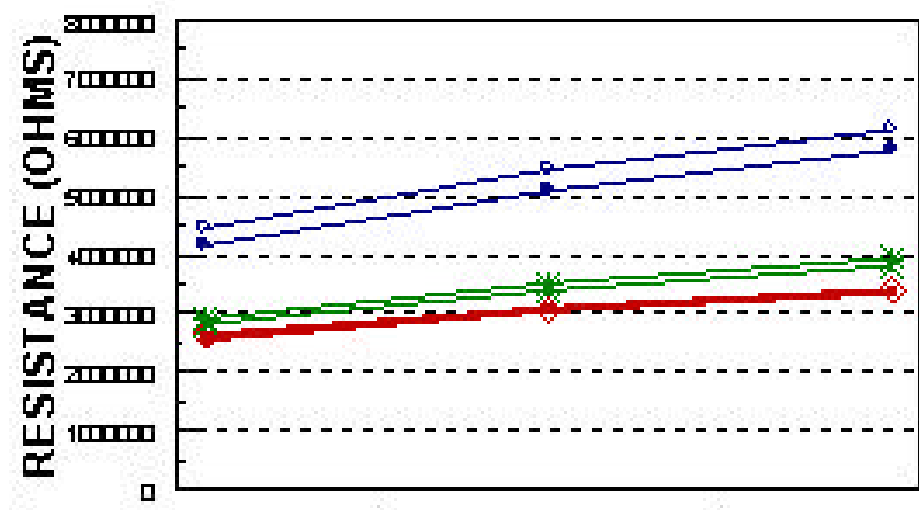

\begin{tabular}{|c|c|c|c|}
\hline DRIE THICKNESS & xuma & In & -Inmer \\
\hline ROZUMGLAZE & 4,0591 & 5,20055 & 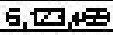 \\
\hline OSTOQLAEEO & $4.4=5$ & $5 \pi \times 405$ & $5 \sqrt{62} 475$ \\
\hline 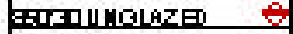 & $28 \times 172$ & $3 \pi 3,725$ & 3205511 \\
\hline FOFOCLLEEEO & 249851 & 3ா2سn & 3 3.10:8 \\
\hline GSODUMCLAZEO & 282511 & $3 \mp=5.1+1$ & 3페됴 \\
\hline BSTMGLFEO & Z던 6,105 & $351+\mathrm{D} 51$ & $35472+1$ \\
\hline
\end{tabular}

Tapel orted THdkress b 18-7lmbars

Emples fred InC ER 1 (I

Figure $\mathrm{H}-9$ 


\section{THICKNESS \& RESISITIVITY COMPARISON}

\section{DUPONT 2061(1MEG OHM PER SQUARE)}

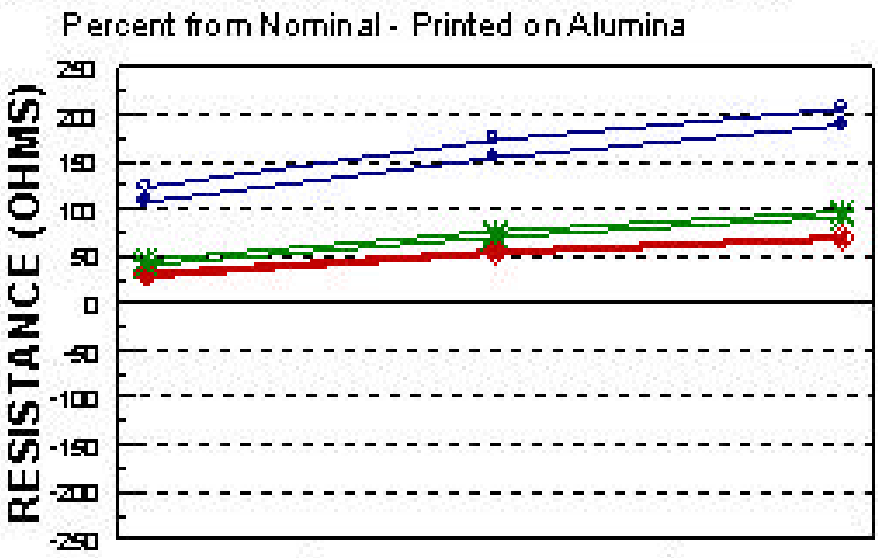

\begin{tabular}{|c|c|c|c|}
\hline DRIFחTHICKNESS & эมレルn & -1 Kar. & •Inーn \\
\hline BSTOULLEED A & 173 & 173 & $\mathbf{D 5}$ \\
\hline 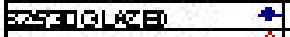 & $1 \mathrm{TS}$ & 154 & \&g \\
\hline SSTRDUMLERER & 페 & 5 t & 国 \\
\hline SETRDOLLEET & 五 & St & 요 \\
\hline RSEDUMLEEED & 41 & ה & 91 \\
\hline TSTOGLEE & 6 & 76 & 97 \\
\hline
\end{tabular}

Tagel orted Thokres b 18-0]miars

Emples fredinc EAt 1 (T

\section{THICKNESS RELATIONSHIP}

DUPONT 2061(1MEG OHM PER SQUARE)

Printed on Alumina

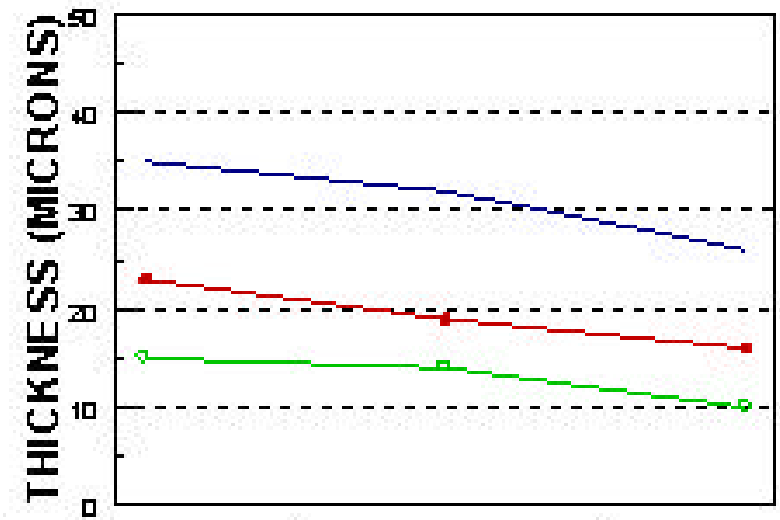

\begin{tabular}{|c|c|c|c|}
\hline GEOMETRY & 25 MIL & 刃 MIL & 1⿴囗十 $\mathrm{IL}$ \\
\hline MET THICKNESS & 35 & 32 & 26 \\
\hline DEIFD THICKNESS - & 23 & 19 & 16 \\
\hline EIRED THICKNESS & 15 & 14 & 10 \\
\hline
\end{tabular}

Tagel brted Thdoress b 18-dimkars

Figure $\mathrm{H}-11$ 


\section{APPENDIX I}

TEST RESULTS FOR LASER TRIMMED

\section{DU PONT 2011 PASTE}

Test Results For the 2011 Paste

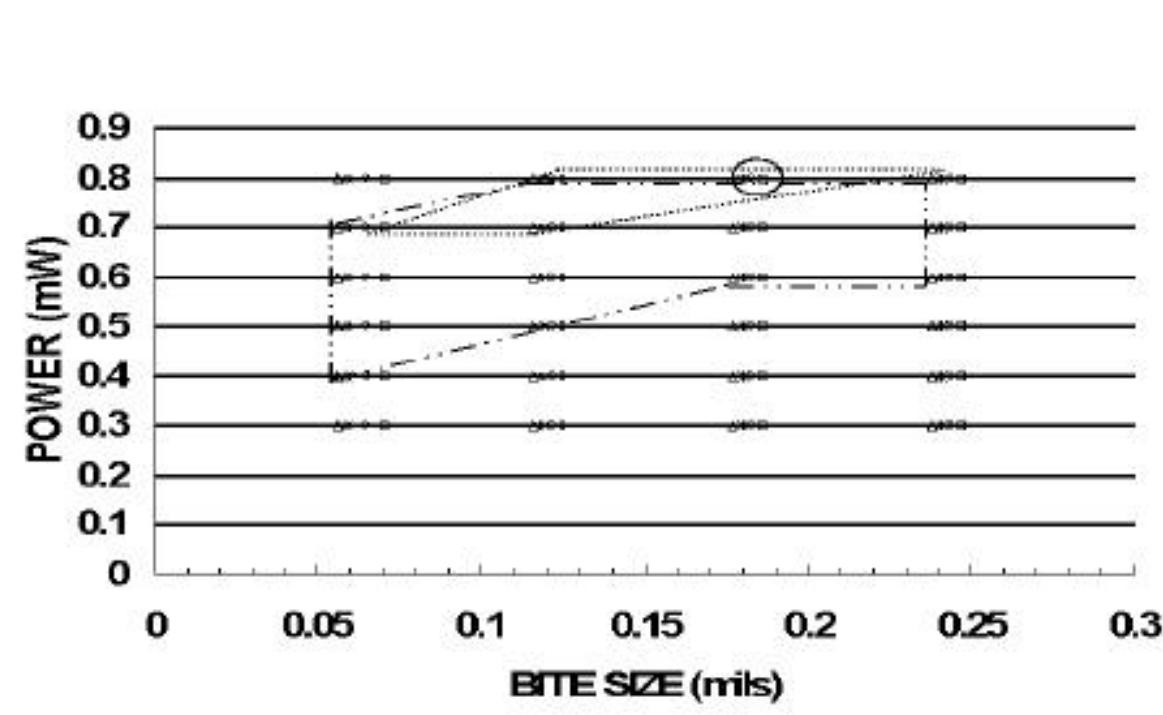

Operating Envelope

Glazed 
82 of 100 
83 of 100 
84 of 100 


\section{APPENDIX J \\ TEST RESULTS FOR LASER TRIMMED}

DU PONT 2021 PASTE

Test Results For The 2021 Paste

Operating Envelope

Glazed
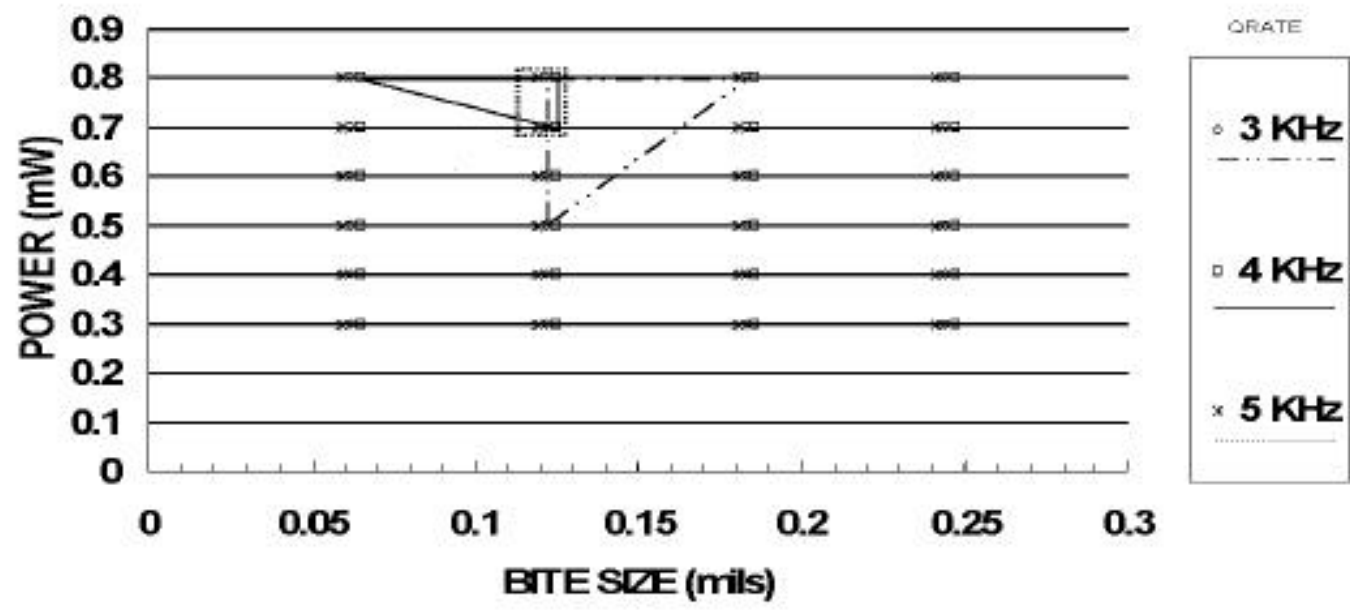


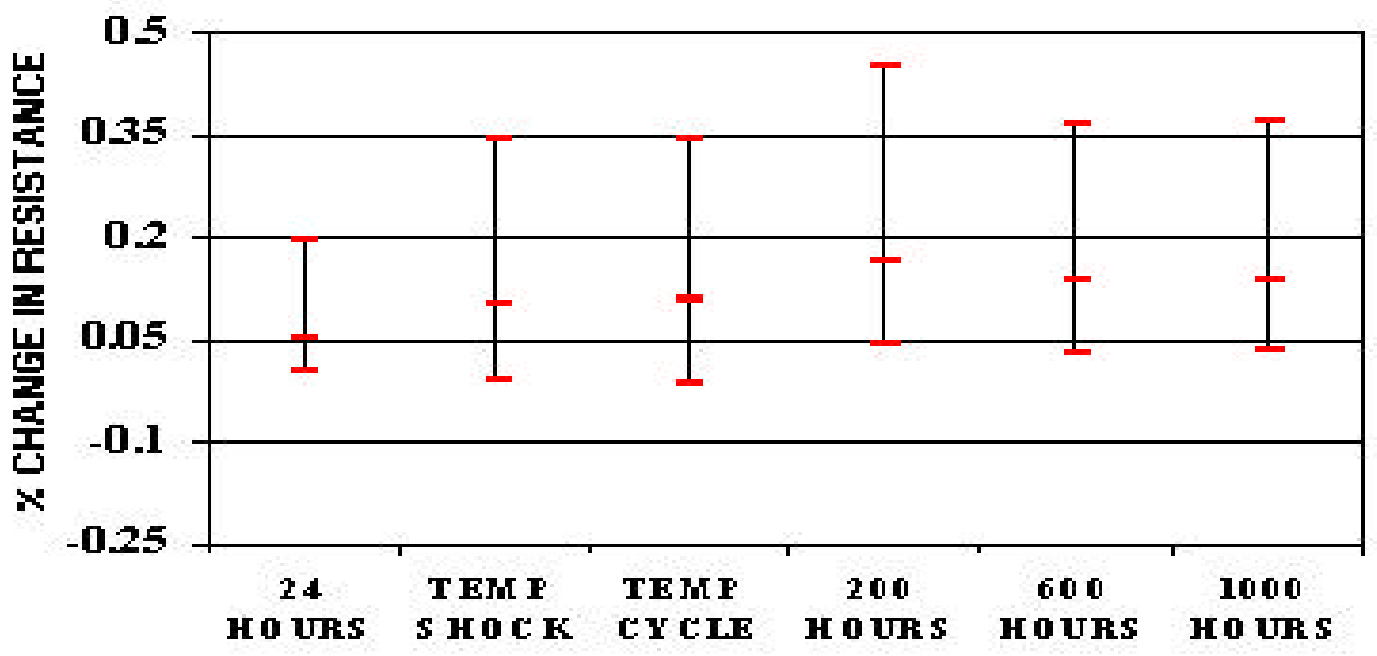

25 MIL

WIDE

RESISTOR

(GLAZED)

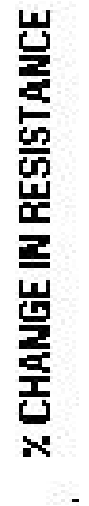


(GLAZED)
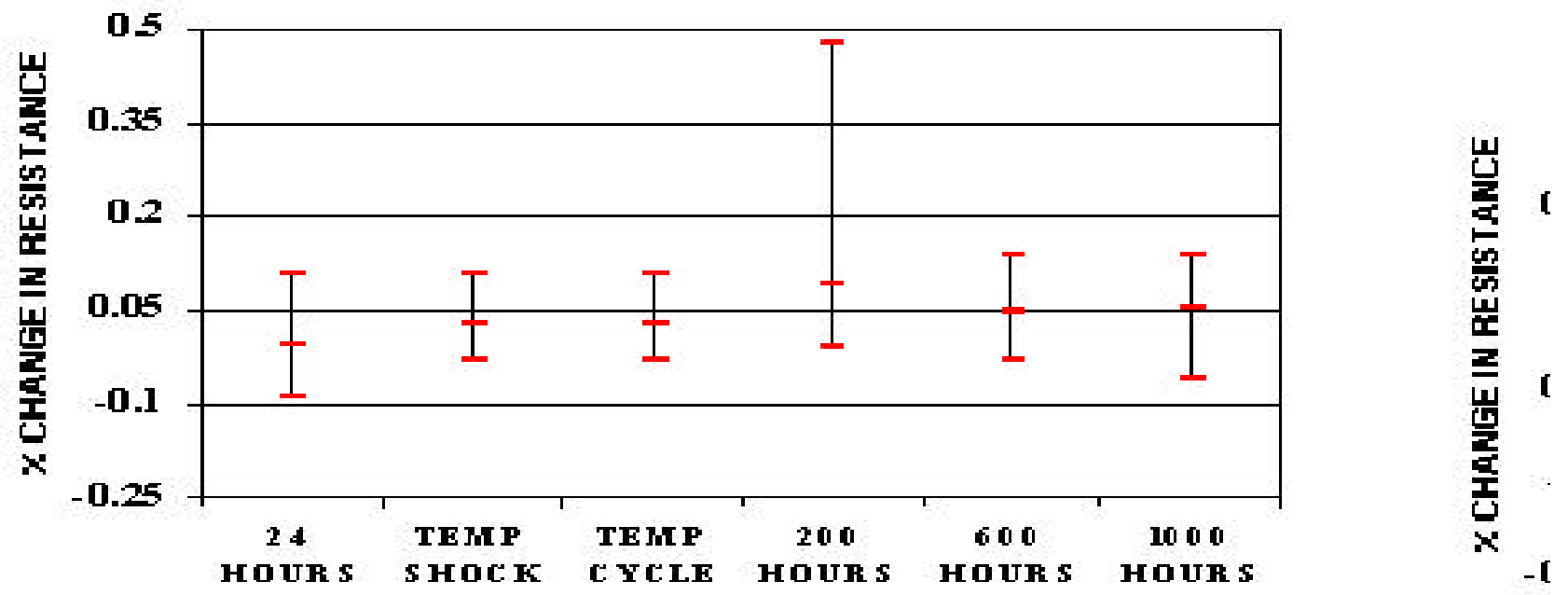


\section{TEST RESULTS FOR LASER TRIMMED \\ DU PONT 2031 PASTE}

Test Results For The 2031 Paste

Operating Envelope 


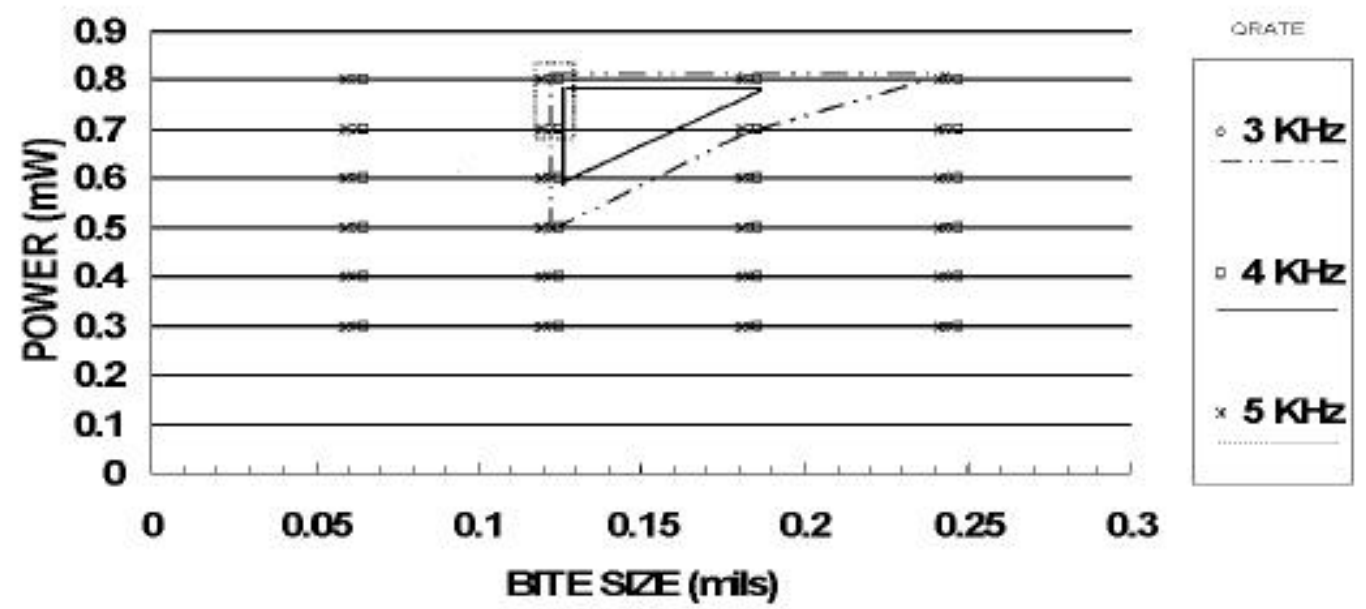


90 of 100 
and Yield.

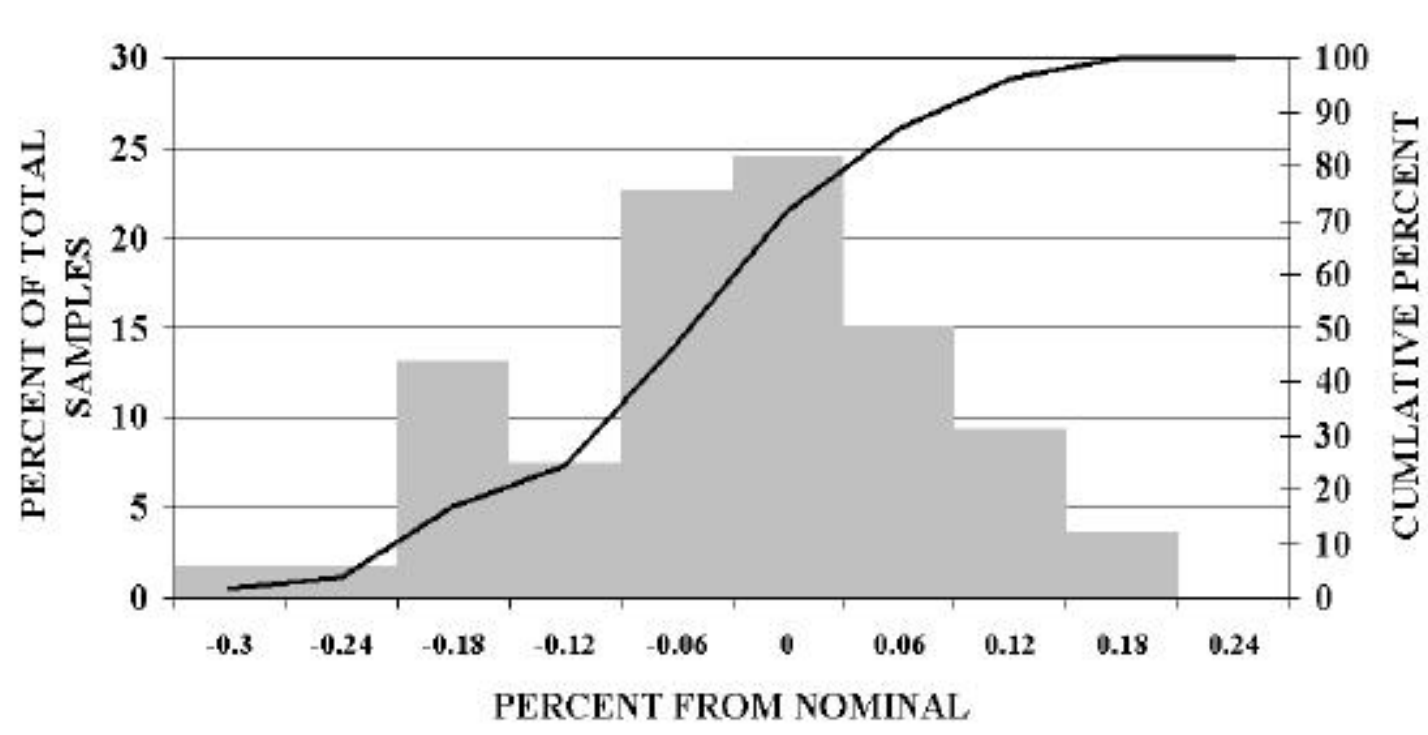

25 MIL

WIDE

(Glazed)

25 MIL

WIDE

RESISTOR

(Unglazed)

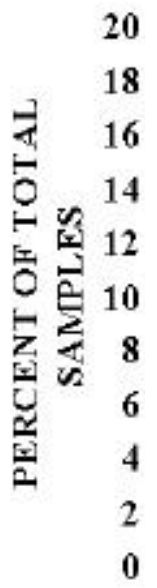


FOR LASER TRIMMED

DU PONT 2041 PASTE

Test Results For The 2041 Paste

Operating Envelope

Glazed

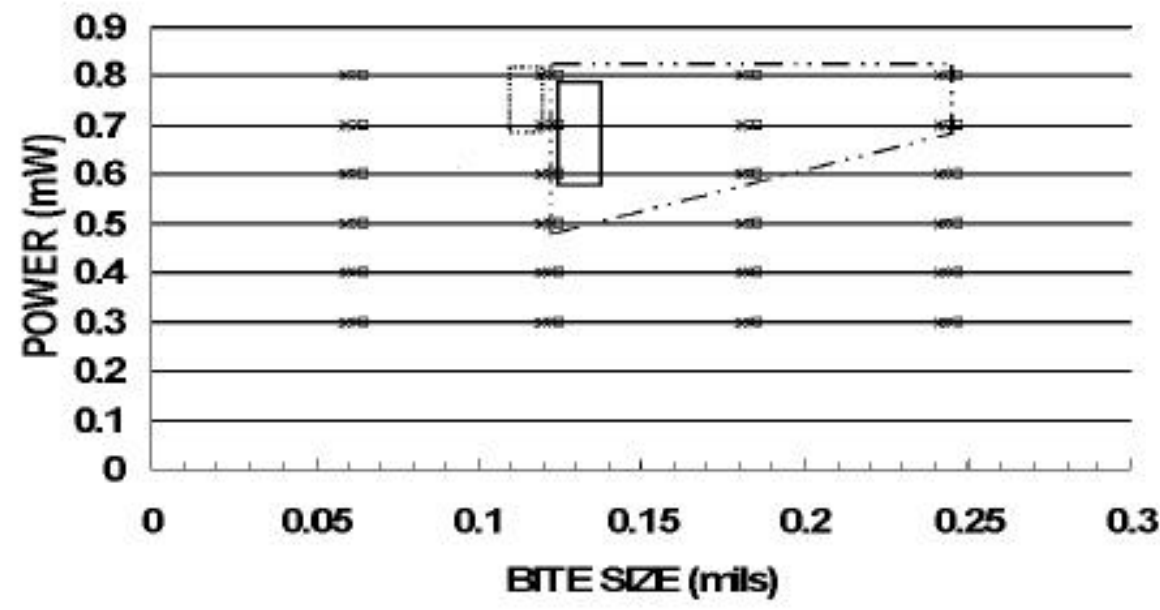

ORATE

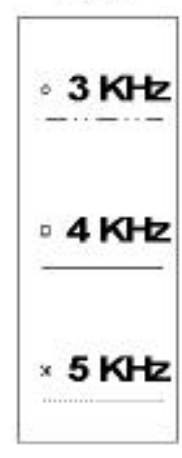


93 of 100 
94 of 100 


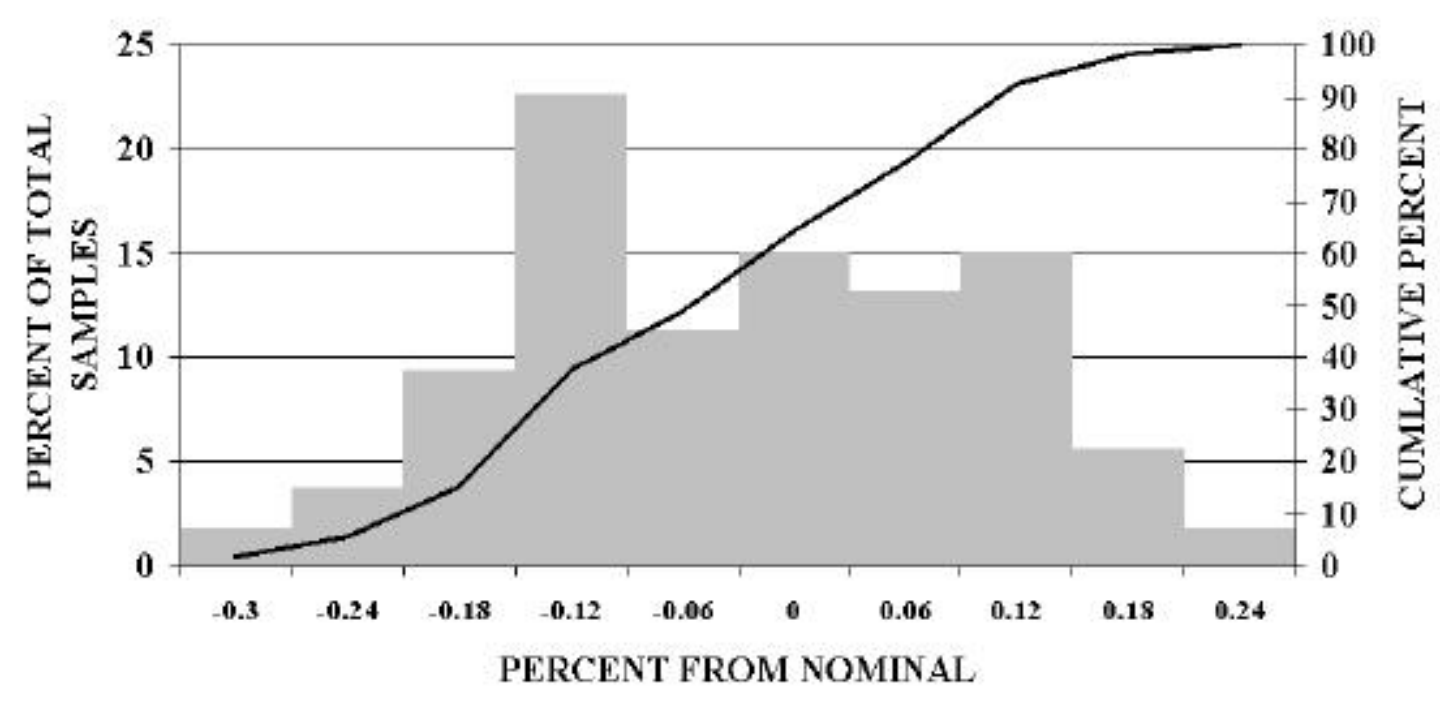

25 MIL

WIDE

RESISTOR

(Glazed)

25

20

0

TEST RESULTS FOR LASER TRIMMED

DU PONT 2051 PASTE 
Test Results For The 2051 Paste

Operating Envelope

GLAZED

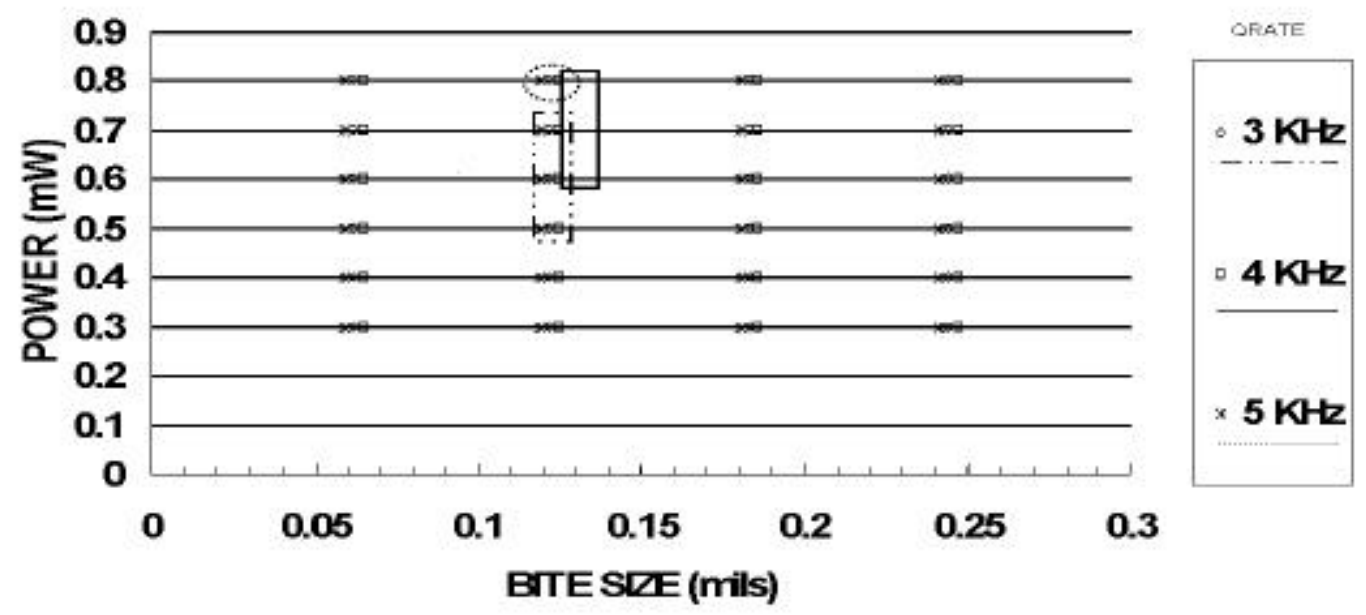


25 MIL

WIDE

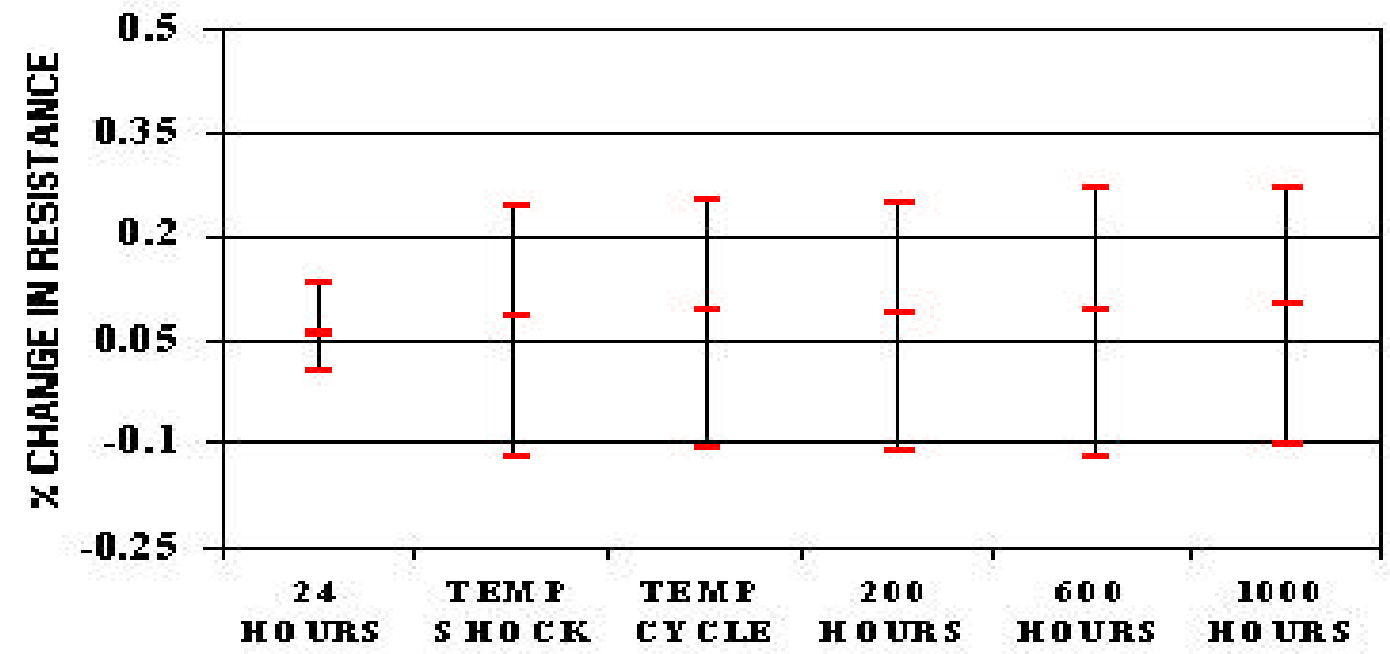

RESISTOR

(GLAZED)

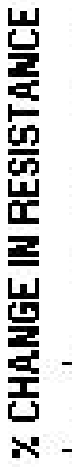


Resistor Tolerance and Yield.

98 of 100 


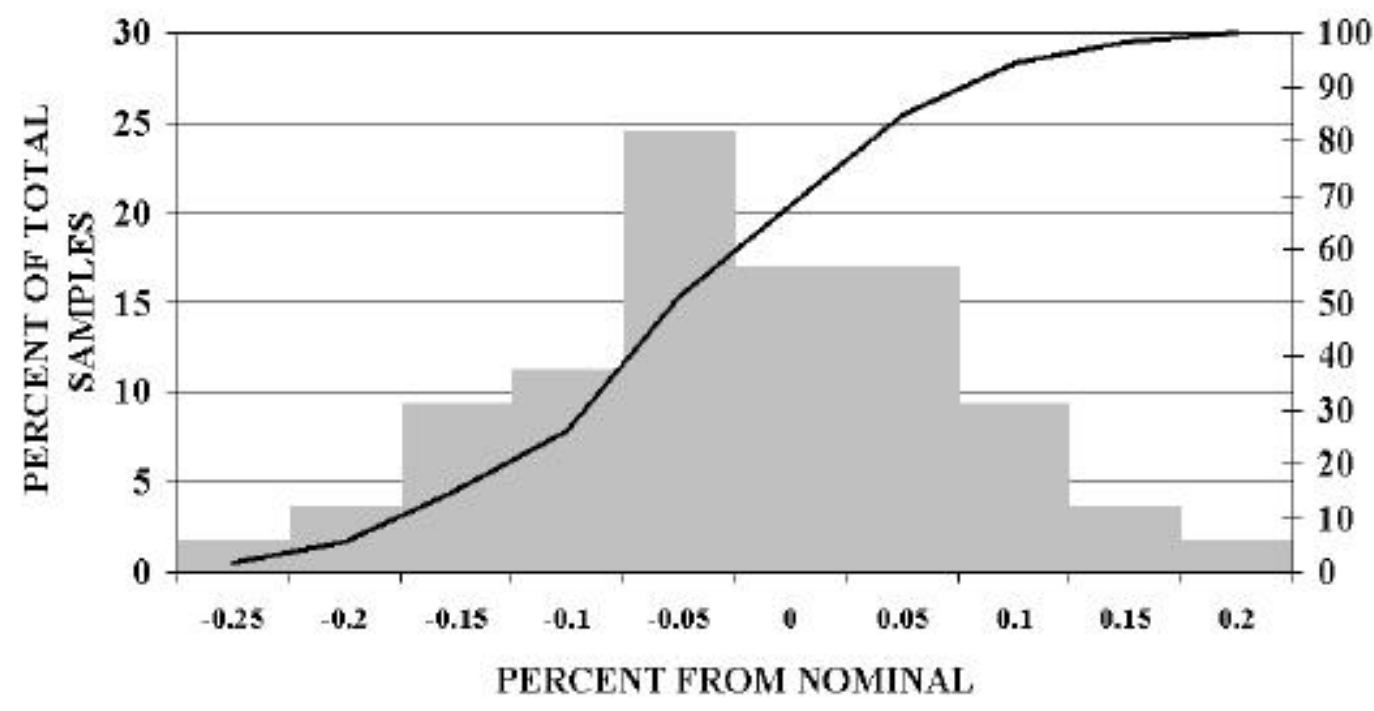

25 MIL

WIDE

RESISTOR

(Glazed)

50

0

$\mathrm{N}$

TEST RESULTS FOR LASER TRIMMED

DU PONT 2061 PASTE 
Test Results For The 2061 Paste

Operating Point

GLAZED
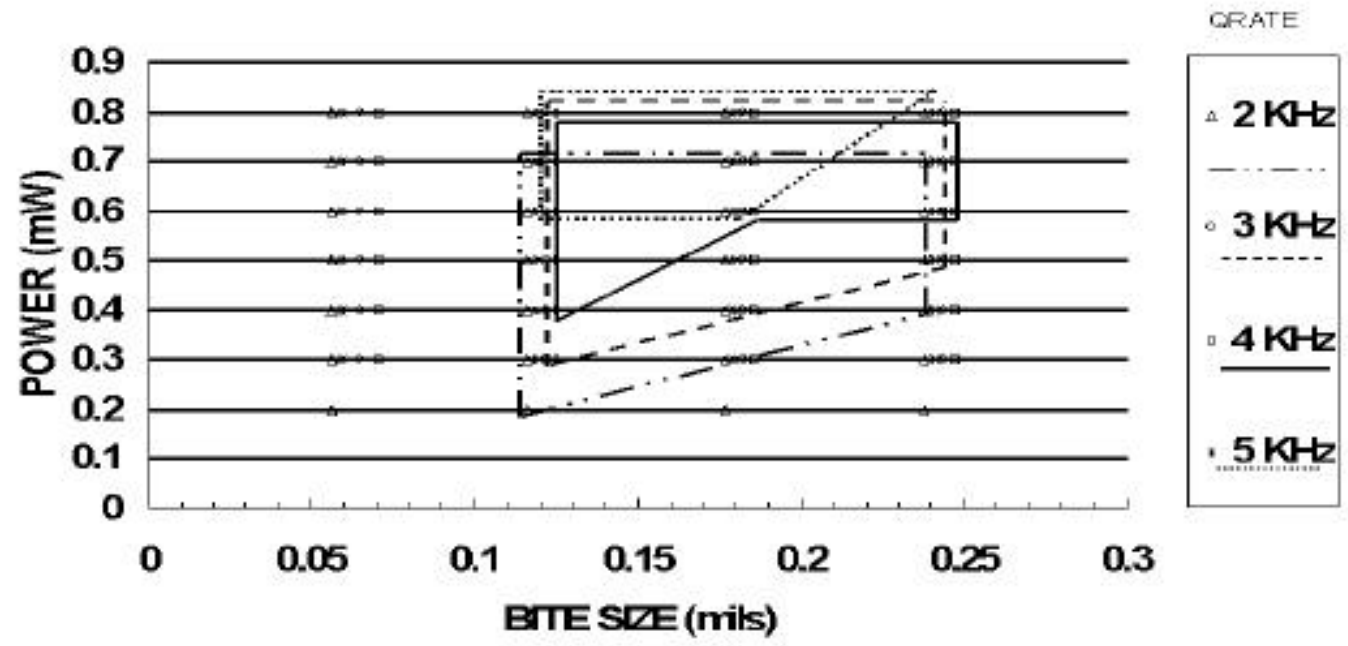